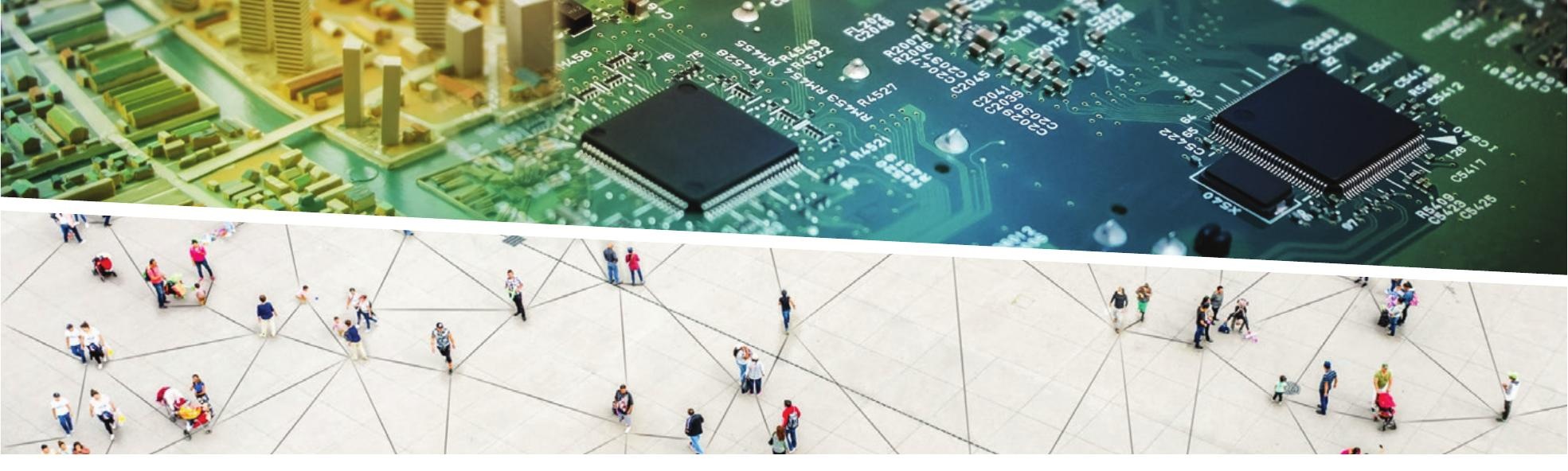

איכות חיים בת־קיימה בישראל

דוח ועדת המומחים של האקדמיה הלאומית הישראלית למדעים

\title{
דיונים נבחרים בגישת ההון לקיימות
}

אסף צחור • אוניברסיטת קיימברידג' והמרכז הבינתחומי הרצליה

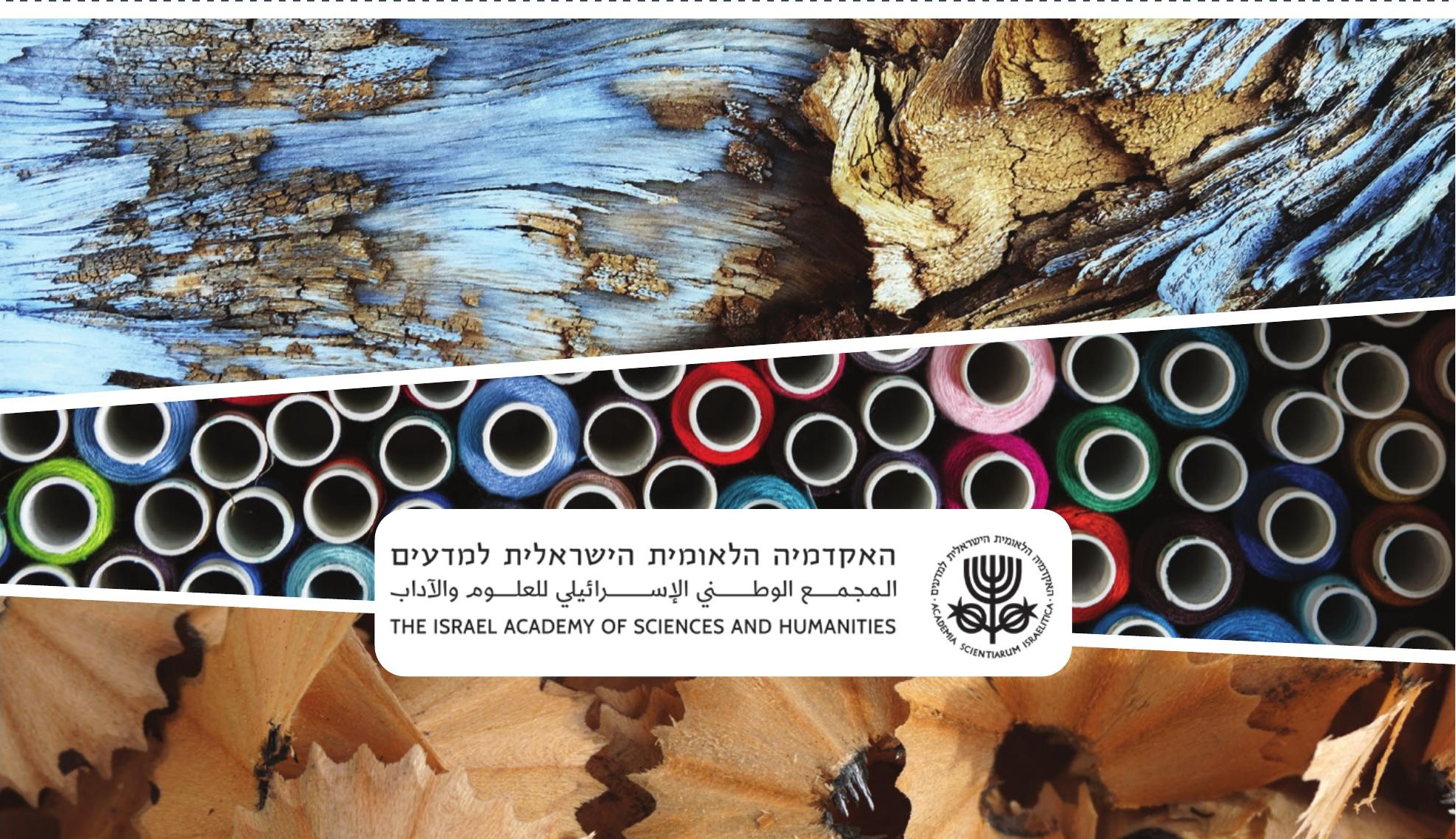




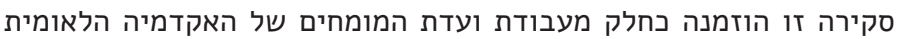
הישראלים למדעים לבחינת מעוזת איכות חיים בת־קים שיימה בישראל. דוח הוועדה זמין באתר האקדמיה. https://doi.org/10.52873/Policy.2021. Wellbeing.

2021 האקדמיה הלאומית הישראלית למדעים (c) המסמך מונגש לציבור הרחב וניתן להשתמש בו בשפת המקור. בכל שימוש בו או ציטוט ממנו ישור לאזכר את להת המקור בדלקמן:

אסף צחור (2021). "דיונים נבחרים בגישת ההון לקיימות", איכות חיים בת־־יקיימה בישראל: דוח ועדת המומחים של האקדמיה הלאומיתית הישית הישראלית ליאלית למדעים. ירושלים: האקדמיה הלאומית הישראלית הלאית למדעים.

https://doi.org/10.52873/Policy.2021.Wellbeing.01

\author{
עריכה: ירדן ניב \\ עריכת לשון: יהודית (דיתיק) ידלין \\ סיוע בהכנה לדפוס: מיה פופר \\ עיצוב ועריכה גרפית: סטודיו נעם תמרי \\ תצלומים: שאטרסטוק
}

האקדמיה הלאומית הישראלית למדעים

כיכר אלברט איינשטיין, ת"ד 4040, ירושלים 9104001

טלפון: 02-5676222, דואר אלקטרוני: info@academy.ac.il

$\underline{w w w . a c a d e m y . a c . i l ~}$ 


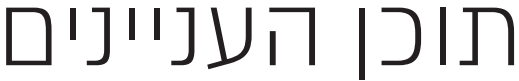

מבוא

מבוא לתאוריית גישת ההון

א. החיים הטובים, פיתוח אנושי ורעיון פונקציית הייצור ב. ארבע הרחבות לרעיון פונקציית הייצור ג. נאוריית גישת ההון לפיתוח ויתרונותיה

סוגים של הון ושל נכסי הון

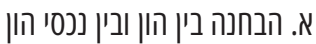

ב. הבחנה בין סוגים של הון הנומין ג. מוזרויות בטבע ובהתנהגות של נכסי הון

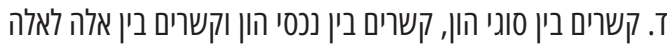
ה. תופעות חיצוניות לשדה האנליטי של גישת ההון

מבחנים לזיהוי נכסי הון קריטיים מבחן ראשון: מבחן הזמינות או מבחן המוגבלות

מבחן שני: מבחן ההתכלוּת מבחן שלישי: מבחן התחליפיות מבחן רביעי: מבחן הזיקה הלאומית משחית משית מבחן חמישי: מבחן הריבונות סיכום א. תחליפיות של נכסי הון ושתי גישות לקיימות ב. טכנולוגיה, קריטיות ותחליפיות של נכסי הון

ג. גישה לנכסי הון ד. אי־ודאות בעת השימוש בננסי הון ה. דרכים ושיטות למדידה של ננסי הון

ו. דינמיקת מערכות וחוסן

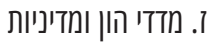

יישומה של גישת ההון בישראל

סיכום 
הסקירה מוסיפה נדבך ביישום גישת ההון לאיכות חיים בת־קיימה בהקשר הישראלי. היא מדגישה את התרומה שמדדי הון צפויים לתרום לתהליכי הפקה והקצאה של משאבים לאומיים וליכולת להעריך את מידת הקיימות של איכות החיים בכללותה. בדרך זו היא פותחת צוהר לדיוני המשך הממוקדים בכל אחד מחמשת סוגי ההון, באפיונם ובזיהוי נכסיהם. 
איכות החיים תלויה תלות מלאה, סופית ומוחלטת בחמישה סוגים של משאבים, המכונים גם מלאים של הון: הון כלכלי, הון טבעי, הון אנושי, הון חברתי והון תרבותי. כאשר משאבים אלו אוזלים, כאשר מלאי ההון מתמצים או מידרדרים באיכותם, הזדמנויות הצריכה מצטמצמות, תהליכי הפיתוח האנושי נפגעים, ואיכות החיים נשחקת. מכאן שהתשובה לשאלה שביסודה

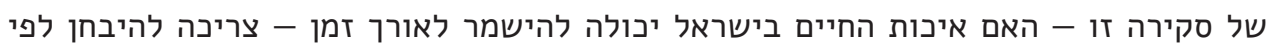
גישה תאורטית ששמה את ההון במרכזה, עוקבת אחריו, חוקרת אותו ומציעה כלים לניהולו - היא תאוריית גישת ההון. גישת ההון היא המסגרת התאורטית המקובלת, האינטואיטיבית והרווחת ביותר להערכת מידת הקיימות של איכות החיים. הגישה שואבת את עולמה המושגי מתחום הכלכלה, ובייחוד מרעיון

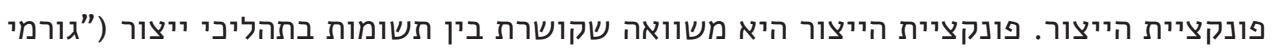
ייצור") ובין תפוקות של תהליכי ייצור ("תוצרים"). אבל השימושיות של פונקציית הייצור לשאלת איכות החיים מתאפשרת רק כאשר אנו מכירים בסוגים שונים של גורמי ייצור, או במילים אחרות, באותם חמישה סוגים שונים של הון.

ההנחה המרכזית של גישת ההון היא שמדיניות לאומית משפיעה הן על מצב המלאי והן על פיזורו של מלאי ההון במרחב ובזמן, ובכך היא משפיעה על תנאי חיי הציבור ונסיבותיהם.' לשיטה זו, כל הסדר פוליטי כולל הקצאת הון המשליכה על העתיד, שבו חיים ומתפקדים הדורות הבאים, ובו האוויר מזוהם או לא, המים ראויים לשתייה או שאינם, הגישה להזדמנויות שווה או מוטה, ורמת האמון הכללית בחברה גבוהה או נמוכה מבעבר. משתמע מכל זאת שסקירה זו נוקטת פרשנות פלורליסטית של המונח "הון". ואכן, התאוריה ויישומה כרוכים ב"הוניזציה" של תופעות ואובייקטים טבעיים, אנושיים, חברתיים ותרבותיים.

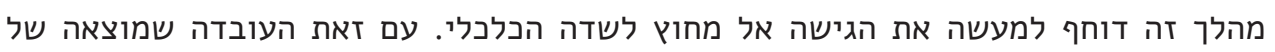
גישת ההון הוא ברעיון פונקציית הייצור עשויה לסייע לנו: המקורות הכלכליים של המונח 
"הון" והטרמינולוגיה הנלווית למונח, למשל מלאי, זרם, נכס, השקעה, צריכה, תחליפיות, טובין, קניין ופחת, מציעים לנו כלים אנליטיים שונים ללמוד, ובמידת הצורך לנהל, סוגים של הון כדי שאלו יתמכו באיכות חיים מתמשכת. עלינו לבחון כמובן אילו מהכלים האנליטיים הללו מתאימים לניתוח סוגי הון שונים.

יישום הגישה יסייע לגזור מרשם המלצות לניהול בסיס המשאבים הלאומי למען איכות חיים מתמשכת. עם זאת לפני אימוצה וקביעת דרך הפעלתה בהקשר הישראלי יש לערוך כמה הבחנות ולתת את הדעת לכמה שאלות. למשל, יש להבחין בעובדה שהון הוא אינו אובייקט הומוגני העשוי מקשה אחת, ועל כן עלינו לברר מאילו פריטים ומרכיבים עשויה כל מחלקת

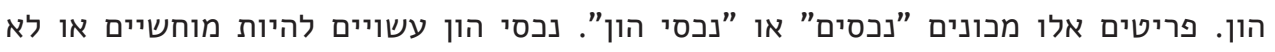
מוחשיים, כלכליים או לא כלכליים, ניתנים לחליפין או לא. עלינו להוסיף ולעמוד על הפערים המהותיים בטבעם בין נכסי הון שונים, וכיצד אלו מגיבים לניצולם ולשימוש בהם. לדוגמה, שימוש בנכס הון אחד עשוי להפחית את כמותו, ואילו שימוש בנכס הון אחר עשוי דווקא להוביל להגדלת כמות המלאי. במקרה שלישי, שימוש בנכס עשוי שלא להשפיע כלל על המלאי. ייתכן גם נכס אשר השימוש בו מגדיל את המלאי עד נקודה מסוימת, וכל שימוש נוסף שוחק את המלאי. דיון זה, בטבע הייחודי של הון מסוגים שונים, מסמן את גבול המטאפורה של פונקציית הייצור.

הואיל ופורטפוליו נכסי ההון של מדינה אינו דבר סטטי - נכסי הון מצויים בשיווי משקל דינמי עם הסביבה החיצונית; הם עוברים שינויים איטיים בתגובה לאינטראקציות - עלינו לתת את הדעת להשפעות השונות בין נכסי הון, ובינם ובין תופעות חיצוניות לפורטפוליו הנכסים. למשל, עלינו ללמוד כיצד הגידול הדמוגרפי או האידאולוגיה משפיעים על הקצאת

ההון בחברה.

זאת ועוד, ההגות בגישת ההון בעשרים השנים האחרונות הותירה אותנו עם שאלה מעשית לא פתורה: לאחר תיחום של סוגי הון לפי מחלקות וזיהוי ממדיהן ומרכיביהן של מחלקות אלו, כיצד נוכל להתמקד בפריטים מסוימים או בנכסים מסוימים לשם המלצה על סדרי עדיפויות בניטור, במדידה ובניהול ציבורי של נכסי הון? במילים אחרות, אם נכסי הון תורמים לאיכות החיים כל אחד תרומה משלו, ואם תכונותיהם שונות בתכלית אלה מאלה, כיצד נוכל לתעדף

נכסים לפי היותם חיוניים יותר וחיוניים פחות? נשות

עד כה מוסדות המחקר והממשל שפיתחו את גישת ההון לא הצליחו להמציא קריטריונים, או מבחנים, לזהות נכסים קריטיים ולתעדף אותם. סקירה זו מבקשת לגשר על הפער שבין הספרות לפרקטיקה. הסקירה מציעה חמישה מבחנים שנועדו לספק כללי אצבע עבור מיקוד בנכסים שנכנה אותם "נכסי הון קריטיים". חמשת מבחני הקריטיות שניתן לראות בהם "מבחני 
חיוניות" או "מבחני חשיבות" כוללים את אלה: מבחן המוּגבלוּת, מבחן ההֶתכלוּת, מבחן התחליפיות או גמישות התחלופה, מבחן הזיקה הלאומית ומבחן הריבונות. רשימת המבחנים איננה רשימה ממצה והיא מוצעת כאן לראשונה. עלינו להוסיף ולבחון את מהותו של כל מבחן ותנאי: אם הוא תנאי מספיק, אם הוא תנאי הכרחי, ומה ההשפעות ההדדיות השוררות בין המבחנים והתנאים. עוד עלינו לשאול, אם יש להרחיב את הרשימה ולכלול מבחנים נוספים. חשוב לציין שתלות בנכס הון היא תלות ארעית. היא עשויה להשתנות עם חלוף הזמן. חדשנות במדע בסיסי ויישומי הדגימה כיצד נכסים עשויים להשיל את חיוניותם, להתייתר, או כיצד כושר ההמצאה האנושי עשוי להגדיל את אפשרויות התחלופה ואת גמישות התחלופה של נכסי הון מסוגים שונים. לכן על העיסוק בגורמי הייצור הקריטיים של איכות החיים בישראל לעבור רביזיה מעת לעת.

מבין המבחנים השונים, מבחן התחליפיות או שאלת התחליפיות - אם ניתן להחליף נכס הון אחד בנכס הון אחר מבלי להתפשר על רמת איכות החיים - היא אחת השאלות המהותיות ביותר בתאוריית גישת ההון. סקירה זו סרטטה שלושה תרחישים של תחליפיות: הנחת תחליפיות מושלמת ומלאה, הנחת תחליפיות חלקית והנחת אי־תחליפיות. תלות בנכס חסר תחליף היא תלות קריטית. עלינו לבחון אמפירית את אפשרויות התחלופה בכל מקרה לגופו, בכל מחלקת הון ובכל עת, לעומת נכסים אחרים. וכן עלינו לתת את הדעת להיבטים הערכיים המעורבים (דהיינו מי קובע מה הוא תחליף ראוי לאיזה נכס הון). זאת ועוד, גמישות התחלופה של נכסים (ורמת הקריטיות שלהם) נקבעת בכלים מדעיים אובייקטיביים, אך היא גם מושפעת מטעמים (דולים תרבותיים. במילים אחרות, לשאלת התחלופה יש היבט נורמטיבי.

מתוך הדיון בתחליפיות נובע דיון בטכנולוגיה - היא אוסף של מכשירים ושל שיטות אשר עשוי לסייע לנו לשמור על רמת איכות החיים לאורך זמן. לשון אחר, אם קיימותה של איכות החיים תלויה בנכסי הון קריטיים, הסקירה שואלת אם הטכנולוגיה מסוגלת לשכך תלות זו; להמציא תחליף ראוי, מדעית ונורמטיבית, לנכסי הון חסרי תחליף לכאורה, או להגדיל את גמישות התחלופה של נכסי הון קריטיים או לייעל את הפקתם וניצולם. כל דיון בנכסי הון צריך להיעשות בשימת לב להשפעות האפשריות של הטכנולוגיה על מצבם ועל התנהגותם

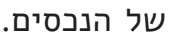
גם שאלת הבעלות על נכסי הון ראויה למחשבה נוספת. הסקירה מציעה סיווג של נכסים ושל טובין לארבע קטגוריות, לפי זכויות הקניין שניתן להחיל עליהם: נכסים ציבוריים, נכסים משותפים, נכסים קבוצתיים ונכסים פרטיים. זכויות הקניין החלות על נכסי הון יקבעו בתורן את זכויות הגישה לנכס. במילים אחרות, ניתן להעביר נכס הון בין משטרי בעלות שונים, ומשמעות ההעברה של נכס מבעלות של אחד - למשל בעלות של הציבור - לבעלות של 
אחר - למשל בעלות של פירמה - היא שינוי בהסדרי הגישה אל נכס ההון: הרחקתו מהישג היד הציבורית, או לחלופין - קירובו. עם השינוי בהסדרי הגישה צצה כדרך טבע שאלת השוויון. עיון בהסדרי הגישה לנכסים הוא בעל חשיבות מכרעת לשאלות מדיניות של צדק חלוקתי ולתפיסת ההוגנות בחברה.

בדומה לשאלת הבעלות והגישה, הסקירה בוחנת את סוגיית אי־הוודאות. דרגה מסוימת של אי־ודאות אופפת את נכסי ההון, ודרגה דומה של אי־ודאות אופפת גם את הצרכים העתידיים של החברה, ומכאן את היכולת שלנו לשמור על קצב ניצול או שימוש בר־קיימה. בתנאים אלו המשק הלאומי עלול לכלות את מלאי ההון העומדים לרשותו ולהעמיד את החברה כולה בסיכון לשחיקת רמת איכות החיים. לכן ניהולו של בסיס המשאבים הלאומי מחייב מנגנון של הערכת סיכונים וניהולם. בעת הדיון בנכסי הון קריטיים עלינו לחקור כיצד ניתן להגדיל את רמת הוודאות בנוגע לכמותם, לאיכותם ולתגובתם לניצול. עוד מוטל עלינו לבחון אם רמה מסוימת של אי־ודאות מצדיקה יישום של עקרון הזהירות המונעת בעת ניצול נכסים.

בנוגע לסוגיית המדידה, ברי כי לא ניתן להעריך נכסי הון השונים זה מזה מהותית ביחידות מדידה זהות. הניסיון לעשות זאת בערכים מוניטריים יוצא מנקודת הנחה של גמישות תחלופה גבוהה עד מלאה - הנחה שאינה משקפת את טבעם של נכסים שונים. נוסף על זה, יש נכסי הון גשמיים ולא גשמיים שערכם הכספי בלתי ניתן לכימות והם אינם נסחרים בשוק. לכן נדרשים מדדים מסוגים שונים עבור נכסי הון שונים: מדדים פיזיים, מדדים תיאוריים, ובמקום שניתן - מדדים מוניטריים, מדדים אובייקטיביים ומדדים סובייקטיביים. מערכת מדדי הון תהיה בהכרח מערכת היברידית.

עוד בנוגע ליישום הגישה, כל המלצה על רגולציה של בסיס המשאבים הלאומי צריכה להתחשב ביחסים הדינמיים ובהשפעות ההדדיות שבין מחלקות הון ונכסי הון. כלים לניתוח מערכות, ובייחוד מתודולוגיית דינמיקת המערכות, עשויים לסייע בכך. המודלים שדינמיקת המערכות מציעה מספקים נקודת מבט אנליטית לתופעות הכוללות, למשל, הידלדלות של נכסי הון קריטיים. על סמך חקר הכשלים (לרבות כשלי שוק), דינמיקת המערכות מתווה דרכי פעולה להתערבות מושכלת במערכות. ואולם שימוש במתודולוגיה לטובת ניהול בר־קיימה של בסיס המשאבים הלאומי כרוך בהשלמת מידע מסוגים שונים ובסינתזה של פיסות מידע אלו. מתוך העיסוק במבנה, במצב ובהתנהגות של מערכות תומכות־איכות־חיים עשויה לנבוע, בין היתר, שאלת חוסנן של מערכות. חוסן מבטא את היכולת של מערכת לספוג זעזועים ולהתארגן מחדש, תוך כדי שינויים שהיא עוברת, בשומרה על אותם תפקודים מהותיים, על אותו מבנה, על אותה זהות ועל אותם מעגלי משוב. שני סוגים של השפעות חיצוניות עלולים להזיק לנכסי הון, ולכן גם לאיכות החיים: הפרעות כרוניות שנובעות מתהליכים של ניצול יתר של הנכס, 
ולכן זעזועים שניתן לצפות אותם מבעוד מועד והפרעות שנובעות מתופעות לא צפויות בעלות פוטנציאל הרסני. על בסיס העיון בסוגיית החוסן, הסקירה המליצה על פיתוח של מדדים מארבעה סוגים וכן על מחקר נוסף בסוגיה.

הסקירה שנועדה לפתח את השדה התאורטי ולסייע ביישומו בתיאטראות המדיניות מגישה תרומה צנועה לספרות במדעי הקיימות, נפי שענף זה הוגדר באקדמיה הלאומית למדעים של ארצות הברית (Clark \& Dickson, 2003; Clark, 2007), וכן תרומה למדיניות ציבורית בישראל ובמחוזות אחרים. היא מוסיפה נדבך ביישום גישת ההון לאיכות חיים בת־קיימה בהקשר הישראלי ומדגישה את התרומה שמדדי הון צפויים לתרום לתהליכי הפקה והקצאה של משאבים לאומיים, לקביעת סדרי עדיפויות בהשקעה במשאבים, לדיון בסוגיית השוויון בגישה למשאבים ובפיזור המשאבים באוכלוסייה וליכולת להעריך את מידת הקיימות של איכות החיים בכללותה. בדרך זו היא פותחת צוהר לדיוני המשך ממוקדים בכל אחד מחמשת סוגי ההון, באפיונם ובזיהוי נכסיהם.

הסקירה מניחה את התשתית לשימוש בגישת ההון בעת עיצוב המדיניות הלאומית וגיבושה כדי להבטיח איכות חיים מתמשכת. ביישום גישת ההון בישראל יש לרכז את הקשב סביב המשאבים הלאומיים החיוניים ביותר ולהנביט השקפה ניהולית הוליסטית ומשותפת המלווה במידע עדכני ומדעי על אודות מלאי ההון. מידע זה יוכל לשמש מחוון למדיניות ציבורית לקביעת יעדיה ולהערכת השפעותיה ארוכות הטווח על איכות החיים.

מבנה הסקירה

סקירה זו ממשיכה כדלהלן וכוללת חמישה חלקים עיקריים: החלק השלישי מציג מבוא לתאוריית גישת ההון ומגולל את הרקע לסקירה, ובמרכזו ארבע הרחבות היסטוריות־ קונספטואליות לרעיון פונקציית הייצור. חלק זה, שנפרס על פני שלושה פרקים, מציע את תאוריית גישת ההון כמרחב אנליטי אפשרי לדיון בבעיית איכות החיים המתמשכת. החלק הרביעי, המורכב מחמישה פרקים, מציג את חמשת סוגי ההון וסוגים שונים של נכסי הון. בפרקים אלו הסקירה מיטיבה להגדיר את מחלקות ההון, בוחנת את השדות הדיסציפלינריים הרלוונטיים לכל מחלקה ומתייחסת לפערים ולמוזרויות בטבע ובהתנהגות של נכסי הון שונים. עוד מציע חלק זה מיפוי ראשוני של קשרים בין סוגי הון, והוא מתעכב לרגע על שתי תופעות חיצוניות לשדה האנליטי של הגישה שמשפיעות על ארגונם של נכסי הון. מטרת חלק זה להתוות את הדרך ליישום התאוריה בהקשר הישראלי. החלק החמישי מציע חמישה מבחנים לזיהוי נכסי הון קריטיים להקשר הישראלי, ומטרתו 
אופרטיבית - לסייע במיקוד מסגרת המדידה הלאומית בנכסי ההון הקריטיים ביותר לאיכות החיים בישראל.

החלק השישי דן בכמה סוגיות מרכזיות המשפיעות על יישום גישת ההון. הוא כולל שבעה פרקים שבכל אחד מהם נסקרת סוגיה אחרת: תחליפיות של נכסי הון, גישה אליהם, השפעותיה של הטכנולוגיה עליהם, היבטים של אי־ודאות בנוגע אליהם ודרכי מדידתם. נוסף על זה, חלק זה דן בקשר שבין גישת ההון לניתוחי מערכות ולהערכת חוסן, וכן בתרומה שעשויה הגישה להציע לתהליכי עיצוב מדיניות. החלק השביעי של הסקירה כולל המחשה קצרה של יישום גישת ההון בישראל. הוא ממציא חמש דוגמאות לנכסים קריטיים בהקשר הישראלי ובוחן אותן לאור הסוגיות שהוצגו בסקירה. 


\section{מבוא לתאוריית גישת ההון}

\section{ג \\ החיים הטובים, פיתוח אנושי ורעיון פונקציית הוייור}

בהנחה שהחיים בישראל טובים, עלינו לשאול אם איכות חיים זו עשויה להוסיף ולהתקיים, ואם כן - לאורך כמה זמן, ובאילו תנאים. סקירה זו מונעת משאלה דומה: האם איכות החיים בישראל בת־קיימה? ובלשון אחר, האם רמת איכות החיים בארץ יכולה להישמר? הסקירה מציגה את גישת ההון בתור התאוריה הרווחת, האינטואיטיבית והישימה ביותר שאותה יש ליישם על מנת להשיב על השאלה אם איכות החיים בישראל היא בת־קיימה, וכיצד ניתן להבטיח את רמתה לאורך זמן.

\section{החיים הטובים}

החיים הטובים, או החיים האיכותיים, הם בראש ובראשונה תופעה פרטית, רב־ממדית, ואם לדייק, מצב אנושי פרטי. מצב אנושי זה, סובייקטיבי בעיקרו, משתנה תדיר, כפוף לתפיסות ולהעדפות אישיות ותלוי בנסיבות חייו של כל אדם ואדם. במילים אחרות, איכות החיים של אדם - האם הוא ממלא את צרכיו ורצונותיו? האם הוא מסופק? - היא תולדה של נסיבותיו. עלינו לשים לב לכך שנסיבות החיים של האדם משקפות גם את ההקשר האקולוגי שבו האדם חי בהיותו מין ביולוגי (Mclntosh, 1986), וגם את ההקשר החברתי שבו הוא נתון בהיותו חיה חברתית (Aristotle, Politics). הנסיבות האקולוגיות והחברתיות מגבילות את האדם, היינו את אפשרויותיו לממש צרכים פיזיולוגיים ומנטליים, ובתוכן הוא מתפקד לבד או ביחסי

גומלין עם זולתו. 
כאשר הוא ניחן באוטונומיה, בשפע יחסי ובאפשרויות, האדם יכול לעצב את הנסיבות החברתיות של חייו. כאשר הוא מתארגן, מקים מוסדות ומשכלל את הכלים שעומדים לרשותו, הוא עשוי לעצב גם את הנסיבות האקולוגיות והחומריות של חיין, ואף לחולל תמורות מרחיקות לכת בסביבתו הטבעית. אפשר לכנות את התהליכים הקולקטיביים הללו תהליכי פיתוח אנושי. מטרתם של תהליכים אלו להשיג את התנאים החומריים הנחוצים לקיום האדם, להסיך תנאים מגבילים מנסיבות החיים שלו, להרחיב את חירותו ואת אפשרויות הבחירה שלו בנוגע למימוש צרכיו - בין שאלו אוניברסליים ובין שלא (Alderfer, 1969) - ולהסב לו רמות גבוהות יותר של סיפוק ורווחה, ובעקבות זאת - איכות חיים כללית משופרת (UNDP, 1997).

\section{הגישה הכלכלית לפיתוח אנושי כנקודת מוצא}

הדיון בתהליכי פיתוח אנושי אינו חדש. מדע הכלכלה כונַן מתוך ניסיון לנתח את הפעילות החברתית המכוונת שתכליתה לייצר, להקצות ולצרוך את הפריטים הנחוצים לרווחת האדם בסביבה של משאבים מוגבלים (Robbins, 2007; Krugman \& Wells, 2012). דיסציפלינה מדעית זו מציעה כלים אנליטיים, מודלים ומושגים ייחודיים שנועדו לסייע בחקר תהליכי הייצור והצריכה של מוצרים ושירותים שתורמים לרווחת האדם. הכלכלה, במילים אחרות, מציעה לנו מרחב רעיוני ושימושי, ראשוני, לבחינת השאלה אם איכות החיים בישראל בת־

קיימה.2

סקירה זו מבקשת לאמץ את אחת מנקודות הפתיחה של מדע הכלכלה, רעיון "פונקציית הייצור", בתור מכשיר אנליטי, או מטאפורה,3 ובאמצעות ארבע הרחבות קונספטואליות בשני הצדדים של המשוואה, בצד גורמי הייצור (התשומות) ובצד התוצר (התפוקות) - אשר רובן ככולן מעוגנות בספרות האקדמית, להציע גישה הוליסטית יותר, רב־ממדית וישימה לפתרון בעיית "איכות החיים המתמשכת". אם כן, התוצאה הסופית של סקירה זו היא הצעה לתאוריה ופיתוחה של תאוריה זו, המאפשרת דיון בגורמים הקריטיים שמשפיעים על איכות החיים הכללית של תושבי ישראל. מתוך התאוריה נובע מודל מרשמי אשר עשוי להשיא לנו עצה בנוגע לארגון החיים הציבוריים וניהול בסיס המשאבים הלאומי־חברתי העומד לרשותנו.4

אנו משתמשים במילה "ראשוני" הואיל ואין בכוחה של הכלכלה להציע מודל שלם, או מסגרת כלכלית טהורה, להשיב על השאלה. חשוב

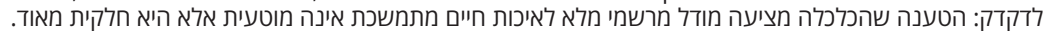

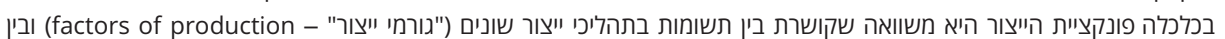

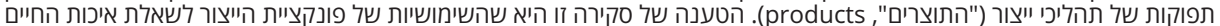

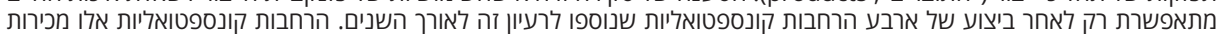

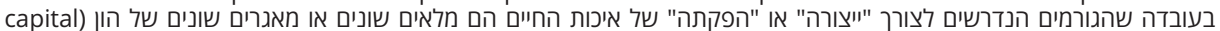




\section{ארבע הרחבות לרעיון פונקציית הייצור}

בשלב זה ברור לנו שרווחת האדם תלויה, בין היתר, באפשרויות הצריכה של פריטים שונים, שחלקם הכרחיים לקיומו (למשל דברי מזון). עוד ברי כי ניתן להרחיב את אפשרויות הצריכה בתהליכים של פיתוח, ושתהליכי פיתוח אלו כוללים בין השאר ייצור, הקצאה וצריכה של פריטים מוחשיים או לא מוחשיים, המכונים מוצרים ושירותים, בהתאמה (למשל תהליכים חקלאיים). במילים אחרות, מאמצי האדם להרחיב את חירותו, להסיר, או למצער לרכך, תנאים מגבילים בסביבתו ולהעשיר את אפשרויותיו לממש צרכים ומאוויים, גלומים בפעילות קיבוצית מכוונת, שעיקרה ארגון וארגון־מחדש של טובין שיסבו לו תועלת (גם פעילויות לא כלכליות או חוץ־כלכליות עשויות להסב לו סיפוק; עוד על טיעון זה בהמשך). מכאן שתהליכי ייצור של טובין, ולמעשה תהליכים שתוצריהם מפיקים תועלת ורווחה, שוכנים לא רק במרכז הכלכלה ובראשית הכלכלה - הן כענף מדעי והן כפעילות חברתית - אלא גם בלב מאמצי הפיתוח האנושי. המונח "ייצור" מיושם ככלל במגוון רחב של מקרים - החל מהפקה של משאבי טבע (בתהליכים של כְְִּּּוּלּ; הפיכת משאב טבעי למוצר כלכלי בעל ערך מוניטרי) וכלה בתהליכים שניוניים ושלישוניים של ייצור מוצרים, למשל הפקה של מוליכים למחצה עבור התקנים אלקטרוניים או עיצוב ממברנות לתהליכי התפלת מים בשיטת אוסמוזה הפוכה. אנו משתמשים במונח "ייצור" שימוש כללי זה על יסוד ההנחה שלמרות השוני בין המקרים הם חולקים מכנה משותף: הפקתם כרוכה בשיטות ייצור (produktionsweise), ואלו מערבות

גורמים מסוגים דומים, המכונים גורמי ייצור או אמצעי ייצור (factors of production). מקובל למדי לבחון את תהליכי הייצור דרך הפריזמה של "פונקציית ייצור" - משוואה שקושרת בין תשומות לתהליך (גורמים) ולתפוקות של התהליך (תוצר). ייצוג פשטני ראשון של תהליך הייצור, החשוב כל כך לרמת הרווחה החומרית החברתית, תואר בדיסציפלינה הכלכלית בפונקציית הייצור. כאן כמות התוצר או התפוקה נקבעת לפי כמות גורמי הייצור וההשפעות ההדדיות ביניהם.

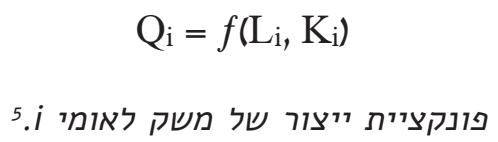

נאשר Q מבטא תפוקה, L מבטא עבודה (העבודה שנעשית לטובת הייצור), K מבטא הון (כאן הכוונה להון כלכלי מיוצר, למשל מכונות).

5

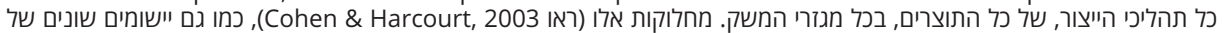
תאוריית פונקציית הייצור, הם מחוץ לגבולות סקירה זו. פונקציית הייצור, כאמור, משמשת כאן לצרכים אחרים. 
הפונקצייה ניחנה באיכות אוניברסלית: עבור כל תפוקה באשר היא נדרשות תשומות משני סוגים - הון ועבודה. דהיינו, אין תוצרים ללא הון ועבודה. הפונקצייה מבטאת גם עיקרון טרנזיטיבי: אם רווחה חומרית תלויה בצריכה של מוצרים (Q) או בבעלות עליהם, אז פונקציית L) הייצור מסייעת לנו לבטא את התלות האמיתית (המלאה) בין רווחה אנושית לגורמי הייצור ו־K), לאמור אין רווחה ללא תשומות הון ועבודה.

אנו משתמשים בפונקציית הייצור בסקירה זו בתור כלי אנליטי, או מטאפורה, ולא בתור מסגרת לחישוב כלכלי. יחסי התלות בין תשומות ותפוקות שהפונקצייה מייצגת הם מענייננו, ובלאו הכי המוניטיזציה המדויקת של הביטויים הסופיים שיופיעו בפונקצייה לאחר ארבע ההרחבות אינה אפשרית. המטרה שלנו היא לשחרר את הרעיון מההקשר הדיסציפלינרי המקורי שלו אל הקשר חברתי ורב־תחומי שבו הוא עשוי להועיל לנו בגישה לבעיית "איכות החיים". לשם כך עלינו לבחון כיצד הפונקצייה (או הרעיון של הפונקצייה) התרחבה תחילה בתוך מדע הכלכלה הודות להתרחבות הפרדיגמטית של הדיסציפלינה לאורך השנים. ארבע ההרחבות שלהלן מסודרות ברצף כרונולוגי, לפי שנות ההצגה שלהן בספרות האקדמית. ההרחבה הראשונה לפונקציית הייצור, מתחילת המאה העשרים, הכירה בקיומו של "הון טבעי" נוסף על ההון הכלכלי. ההרחבה השנייה של רעיון פונקציית הייצור, מאמצע המאה העשרים, עסקה ב"הון אנושי". ההרחבה השלישית להלן, משנות השמונים של המאה העשרים, מכירה

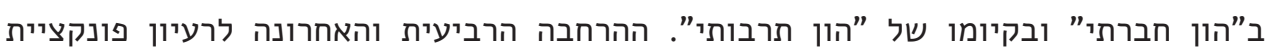
הייצור מבחינה בין רווחה חומרית ובין איכות חיים כללית.

\section{הרחבה ראשונה: הון טבעי - - ה}

ניסיונות להגדרה פלורליסטית יותר של הון נרשמו כבר בתחילת המאה העשרים. בשנת 1902 התייחס אלווין ג'ונסון לפונקציית הייצור הקלאסית וביקש לערוך הבחנה בין תשומות טבעיות בתהליכי ייצור, שאותן הוא כינה natural instruments of production, ולתשומות מלאכותיות בתהליכי ייצור, שאותן הגדיר מartificial instruments of production (Johnson, 1902) הכלכלה" הוא כתב: "אם אנו ממשיכים במחשבה (של ג'ונסון), נבחין בשני סוגים של הון, מלאכותי וטבעי. הון טבעי עשוי לכלול 'אדמה' ו'גורמים טבעיים שונים', והון מלאכותי כולל אינסטרומנטים מיוצרים". ג'ונסון, שהיה למבשר הפלורליזם בהמשגת "הון" (בתור מלאי יצרני

בשנת 1909 כתב ג'ונסון בספרו "מבוא לכלכלה": "זה שנות דור, שכלכלנים מגבילים את המונח 'הון' למלאי פרודוקטיבי כלשהו שיוצר

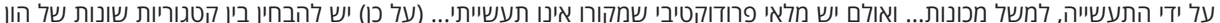

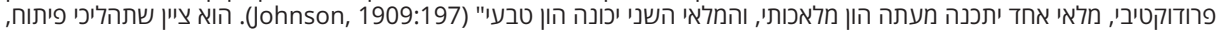

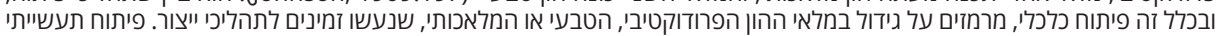

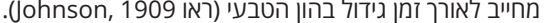


כלשהו), נשען בעצמו על הרחבות מוקדמות של המונח שהציען, כל אחד בנפרד, קלארק בין Fisher, 1896, 1897,) ופישר בין 1888 ל־1896 (Clark, 1888, 1891, 1899) 1906).' ברעיון "הגורמים הטבעיים השונים" ג'ונסון פתח צוהר לדיון במרכיבים שונים של הון והעלה, אגב אורחא, את האפשרות שהון אינו מלאי הומוגני. אפשרות זו תידון בהמשך. כך, פונקציית הייצור התרחבה, הודות להתפתחות הדיסציפלינה הכלכלית, לכלול מחלקה חדשה של נכסים יצרניים.

\author{
$\mathrm{Q}_{\mathrm{i}}=f\left(\mathrm{~L}_{\mathrm{i}}, \mathrm{K}_{\mathrm{Ei}}, \mathrm{K}_{\mathrm{Ni}}\right)$ \\ פונקציית ייצור של משק לאומי i.
}

או בנוסח כללי - - - n

$$
\mathrm{Q}=f\left(\mathrm{~L}, \mathrm{~K}_{\mathrm{E}}, \mathrm{K}_{\mathrm{N}}\right)
$$

כאשר Q מבטא תפוקה, L מבטא עבודה, KE מבטא הון כלכלי (כאן הכוונה להון כלכלי מיוצר, למשל מכונות, מה שג'ונסון מכנה הון מלאכותי), KN מבטא הון טבעי (אדמה

$$
\text { וגורמים טבעיים). }
$$

\title{
הרחבה שנייה: הון אנושי
}

הרחבה נוספת נרשמה בצד גורמי הייצור בשנות החמישים והשישים של המאה העשרים. בשנת 1928 עשה ארתור פיגו ניסיון ליישם את הז'רגון ההוני בגורם הייצור "עבודה".9 ניתן להשקיע גם בהון חומרי וגם בהון אנושי, ויש להכיר בכך, הוא טען בחיבורו "מחקר במימון ציבורי" (Pigou, 1928). מהלך זה שוחזר בשנת 1958 בחיבורו של מינסר על "השקעה בהון אנושי" (Mincer, 1993). ואומנם, הדיון המקיף ביותר בהון אנושי נרשם בשנת 1964 עם פרסום "הון אנושי" של גארי בקר (Becker). בקר גרס שבראי תהליכי הייצור (ובראי רעיון פונקציית הייצור) הון אנושי דומה באיכויותיו לאמצעי ייצור פיזיים המכונים "הון כלכלי" וכוללים מפעלים ומכונות. לשיטה זו, הקניית כישורים, חינוך וטיפול רפואי משולים להשקעה בסוג הון זה, ואת התרומה (או ההחזר) להשקעה ניתן לראות בשיפור בתהליכי ייצור. הון

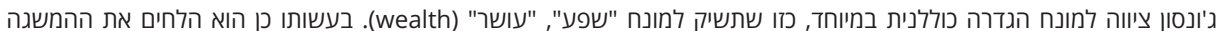

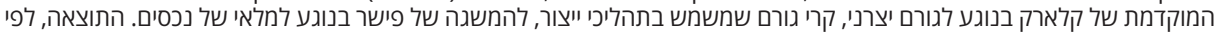

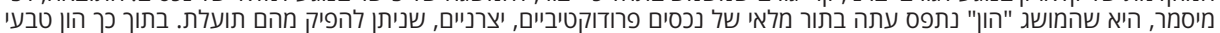
היה למחלקה אחת של הון, סוג אחד של מלאי, ששימש בתהליכי ייצור (Missemer, 2018).

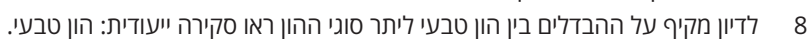

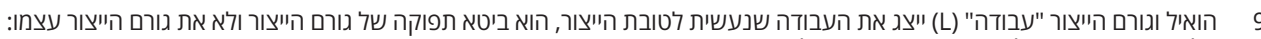
מלאי ההון האנושי (כלומר היה ביטוי עקיף של ההון). 
אנושי, במילים אחרות, הוא אמצעי לייצור טובין.10 אם אנו מארגנים מחדש את פונקציית הייצור, לנסח ניסוח מלא וקפדני יותר את התשומות, אנו מקבלים:

$$
\mathrm{Q}=f\left(\mathrm{~K}_{\mathrm{H}}, \mathrm{K}_{\mathrm{E}}, \mathrm{K}_{\mathrm{N}}\right)
$$

כאשר KH מבטא הון אנושי, הוא מקור העבודה בפונקצייה הקלאסית (שם הוא מכונה L).

רעיון הייצור, ובעקיפין האמצעים שתורמים לרווחה חומרית, הורחב לכלול מחלקות שונות של הון, וכל אחת היא קטגוריה של גורמי ייצור. עתה היה אפשר לבחון את מחלקות ההון ה"חדשות", הון טבעי והון אנושי, למול תופעות כלכליות ועקרונות כלכליים שנשמרו עד כה לדיון בהון כלכלי מיוצר, למשל שימוש, פְחָת," תחלופה"12 והשקעה.13 למותר לציין שרעיונות כלכליים אלו חלים באופנים שונים על סוגים שונים של הון; אין דין פחת במלאי ההון הטבעי כדין הפחת במלאי ההון הכלכלי המיוצר. כמו כן השקעה - והערכת ההחזר על השקעה בהון אנושי לובשת צורה שונה מזו שלובשת השקעה בהון כלכלי. אפשר ששימושיות המונחים מוגבלת למחלקות שונות של הון.

\section{הרחבה שלישית: הון חברתי והון תרבותי}

הרחבות אלו, שנשענו על תצפיות בתהליכי ייצור, וההכרה שגורמים שונים, חדשים לכאורה, נחוצים לתהליכים אלה, הובילו לתיאורים נוספים של אמצעי ייצור ולהגות פוסט־כלכלית במושג. פייר בורדייה קרא בספרו "סוגים של הון" משנת 1986 לבחינה מחודשת של המונח והגדיל לעשות בהפרידו בין דגמים של הון. אם אנו יוצאים מנקודת הנחה שהון הוא מלאי נכסים יצרניים, ${ }^{14}$ כלכלי, הון חברתי, הון תרבותי והון סימבולי (Bourdieu, 1986)

10 הרעיון של הון אנושי, על היבטיו השונים ועל תרומתו לתהליכים כלכליים, הופיע כבר בכתבי אדם סמית', אם לא במפורש אז ודאי במשתמע. סמית' טען שהיכולות הנרכשות והמעשיות של חברי הקהילה היציצרנית - קרי השכלה, מיומיומנויות וכישורים של האוכלוסייה -

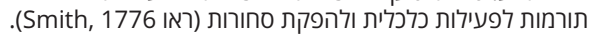

11 המונח "פחת" מייצג את הירידה בשוויו של נכס הון לאור לפורך תקופת השימוש בו (או בתקופת הבעלות עליו). הירידה בשווי נכס ההון

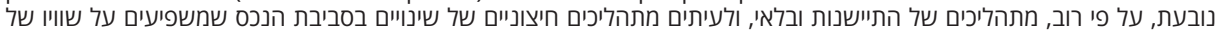

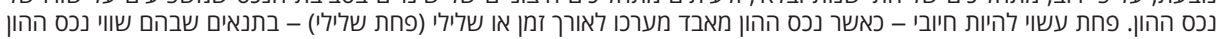

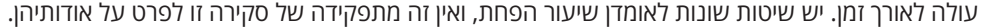
12 המונח "תחלופה" מבטא את הרעיון שנכס הון אחד יכול, בשיעור מסוים, להיות תחליף לנכס הון אחר בתהליכים של ייצור. סקירה זו מרחיבה בנושא התחלופה וגמישות התחלופה בהמשך.

13 המונח "השקעה" מייצג תהליכים של הקצאת הון (במקור הכוונה להון כלכלי פיננסי - כסף) לטובת ייצור או רכישה של נכסים מסוגים

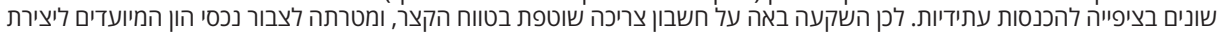
נכסי הון נוספים בעתיד, אשר בתורם יניבו תשואה (למשל ריבית או רנטה). ניתן לחשוב על על השקעה כסוג של חיסכון של משאבים עם

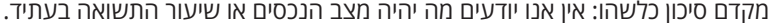
14

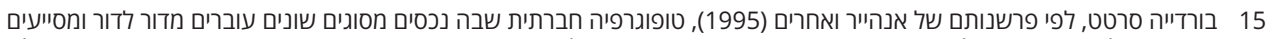

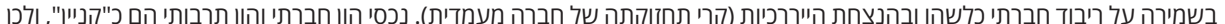
הגישה אליהם עשויה להיות מוגבלת (exclusive): זה המקרה של הקניית ערכים ותבניות קוגניטיטיביות, סיגול התנהגות ואימוץ נורמות וגינונים שילדים עשויים להפנים ולאמץ מהוריהם - ואך ורק מהוריהם, בני מעמד חברתי כלשהו - וכך, לשעתק מבנים חברתיים לאורך זמן (ראו Anheier et al., 1995 (A) 
ההמשגה של נכסים לא חומריים כמלאי הון אפשרה לבורדייה לדון באפשרויות החליפין, או אופציות התחלופה, בין נכסי הון למחלקות הון. בורדייה הדגים כיצד סוג של הון תרבותי, שאותו הוא מגדיר הון תרבותי ממוסד (אסמכתה ממוסד אקדמי), 16 יאפשר למאן דהו גישה להון כלכלי. מנגד, כל מי שאינו מפגין גינונים מסוימים (שאותם בורדייה מגדיר הון תרבותי

מופנם, משמע בר־הפנמה) עלול למצוא עצמו מודר מגישה לשימוש בנכסי הון אחרים.17

Coleman,] אם מקובלת עלינו הפעילות של בורדייה ושל הוגי דעות אחרים (למשל קולמן 1988], פוקויאמה [Pukuyama, 1995], פטנאם [Phromam, 1993] ות'רוסבי [Throsby, 1999) לבירור משמעותו של המונח "הון" ולעיון במערך אמצעי הייצור הכלכליים, ואם מקובלת עלינו הקביעה שהון עשוי להתייחס לנכסים חברתיים ותרבותיים שאינם רק לא חומריים אלא גם לא כלכליים (בעלי ערך אך משוללי מחיר; שלא ניתן לסחור בהם), אז כיצד ניתן ליישם את הפרשנות המרחיבה עבור רעיון פוקנציית הייצור? סקירה זו מציעה למתוח את אגף גורמי הייצור בפונקצייה עד שזה יכלול את צורות ההון החברתי והתרבותי. אומנם מהלך זה מוציא את רעיון הפונקצייה אל מחוץ להישג ידה המוניטרי של הכלכלה, ואפשר שגם מחוץ לשדה הדיסציפלינרי אחת ולתמיד, אך הוא מיטיב להביע את ההנחה שהמשוואה הקלאסית אינה משקפת את סך התשומות ההוניות המעורבות

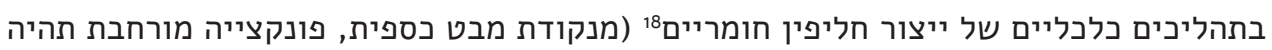
פונקציית כלאיים: עשויה גורמי ייצור כלכליים וגורמי ייצור לא כלכליים; המדידה המדויקת

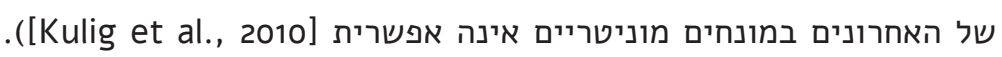

$$
\mathrm{Q}=f\left(\mathrm{~K}_{\mathrm{H}}, \mathrm{K}_{\mathrm{S}}, \mathrm{K}_{\mathrm{C}}, \mathrm{K}_{\mathrm{E}}, \mathrm{K}_{\mathrm{N}}\right)
$$

כאשר Q מבטא תפוקה, KH מבטא הון אנושי, KS מבטא הון חברתי, KC מבטא הון תרבותי, KE מבטא הון כלכלי (כאן הכוונה להון כלכלי מוחשי ולא מוחשי), KN מבטא הון טבעי.

מלבד הרחבות אלה יש לבחון את אפשרות הצריכה הישירה של הון, או גישה ישירה למלאי ההון, לטובת הפקת תועלת - נוסף על תהליכי ייצור כלכליים. דהיינו, האפשרות של אדם להפיק סיפוק באופן בלתי אמצעי (קרי בלתי "מיוצר") מנכסים טבעיים שונים או מאלמנטים שונים של הון תרבותי. כמו כן עלינו לשקול את האפשרות שרווחה חומרית היא תנאי הכרחי אך לא מספיק לרווחה כללית, ואם כך, ייתכן שעל התוצר החומרי לפנות את מקומו לתפוקה

16 הוגים אחרים יגדירו השכלה כנכס הון אנושי.

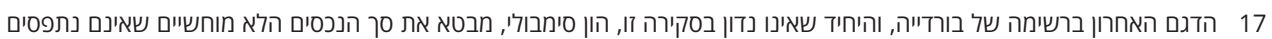
בעיני החברה כנכסי הון, למשל "יוקרה". גם לנכסים לא חומריים אלו, שמשך חייהם אינו מוגדר (בשונה, למשל, מבעלות על פטים פטנטים

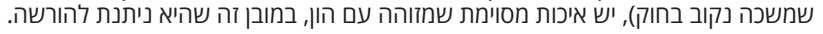
18 מצד אחד קל לדמיין את התרומה של אמון לתהליכי ייצור כלכליים, ומצד אחר קשה לנקוב בשווי של אמון. 
שלמה יותר, רב־ממדית, שניתן לכנותה: "איכות חיים". שתי המחשבות הללו מזמינות הרחבה קונספטואלית רביעית לרעיון פונקציית הייצור.

\section{הרחבה רביעית: איכות חיים}

עד כה ראינו ב"ייצור" את השיטה הבלעדית ליהנות ממלאים שונים של הון. לפיכך ערכנו שלוש התאמות בצד אמצעי הייצור של הפונקצייה. מטרתן הייתה לעיין בגורמים המעורבים בהפקה של חליפין חומריים (טובין, פריטים חיוניים), ובעת הצורך - להגדיר את אמצעי הייצור מחדש כדי שהמודל (רעיון הפונקצייה) ייטיב ללכוד את מהותם של תהליכי ייצור ולשקף שיקוף מהימן יותר את המציאות: העובדה שסוגים שונים בתכלית של הון מעורבים

כתשומות בתהליך.

אולם מרגע שאנו שוקלים הנאה ישירה ממלאי הון והפקת סיפוק מהגורמים המרכיבים את מלאי ההון כאפשרויות ממשיות; מרגע שאנו משערים כי אדם עשוי להפיק תועלת מחשיפה

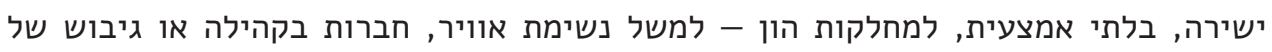

תחושת שייכות - ואף להיות תלוי בה, עלינו לבחון מחדש את צד התפוקה בפונקצייה.19 בדומה לזה, פעלנו מתוך הנחה שתוצר כלכלי הוא ערובה לרווחה (ומכאן שצמיחה בתוצר תוביל לצמיחה ברווחה הכללית). אבל הנחה זו, שביטויה העז ביותר היה קיבעון ארוך שנים של ממשלות בהגדלת התוצר הלאומי הגולמי (תל"ג) או התוצר המקומי הגולמי (תמ"ג) כתנאים לרווחה ומחוונים של רווחה, איבדה מתקפותה בעשורים האחרונים (Stiglitz et al., 2009). ייצור מוצרים, בעלות על טובין וצריכה של חליפין ושירותים (וגם הציפייה של אנשים באשר לאפשרויות הצריכה העתידיות שלהם [Dasgupta, 2001]) תורמים לרמת השגשוג הפרטית ולרווחה חומרית (Samuelson \& Nordhaus, 2004), אך פריטים אלו, חיוניים ככל שיהיו, הם אך נדבך אחד בתוך מכלול רב־ממדי של תועלות וסיפוקים שאנשים עשויים להפיק גם ממרכיבים ומתופעות לא מוחשיים ולא כלכליים.20 ואכן, בשנים האחרונות אנו עדים לשימוש גובר והולך במונח "איכות חיים" כתחליף למונח "רווחה" בתור היעד האולטימטיבי של תהליך הפיתוח האנושי. אם המילה "רווחה" עמדה לייצג היבטים חומריים של איכות החיים הכללית, היבטים שקשורים בהכנסה, או במילים כלליות יותר - הסיפוק שאדם עשוי להפיק מצריכה של מוצרים ושירותים,

19 מפרספקטיבה זו ניתן לראות בתהליך ההפקה של טובין דרך אחת, מלאכותית ועקיפה, ליהנות מסוגים שונים של הון (בגלגולם

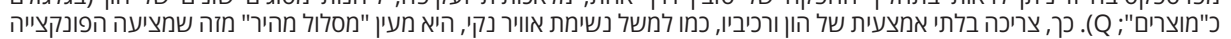

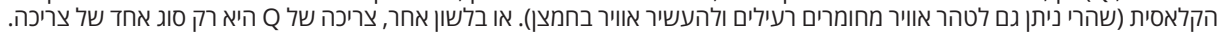

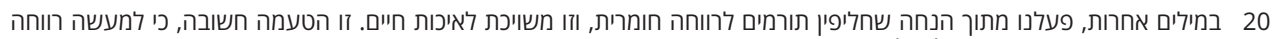
חומרית משויכת, אך אינה שקולה, לאיכות חיים. 
המונח "איכות חיים" נוקט עמדה כוללנית יותר, פוסט־חומרנית ומרחיבה (הוא מותיר מקום, למשל, לבריאות נפשית, למערכות יחסים ולחירות פוליטית). לפי כהנמן ואחרים, ההבדל המהותי בין השניים מחייב הגדרות אופרציונליות נפרדות, ועל המונח "איכות חיים" לבטא את רב־הממדיות של מה שאנו יכולים לכנות "החיים הטובים" (Kahneman et al., 1999). ברוח זו טען פרת'ה דסגופטה (Dasgupta, 1995) שאיכות חיים מייצגת הן תועלות הנובעות מצריכה של טובין והן סוגים של סיפוק שאינם מותנים בצריכה של חליפין במנגנוני השוק. הארגון לשיתוף פעולה ולפיתוח כלכלי (להלן: OECD) סמך ידו על הפרשנות המרחיבה של המונח בסקירות מדעיות ובניתוחים סטטיסטיים רבים (OECD, 2013a, 2011; Durand, 2015). תנועה שלמה של ממשלות וארגונים רב־לאומיים, לרבות ישראל, מבקשת עתה להציב את המדידה (והשיפור) של רמת איכות החיים בראש סדר העדיפויות.

מגמה זו, של החלפת המונח "רווחה" במונח "איכות חיים", נבעה מתצפיות במצב האנושי, שהובילו לתאוריות חדשות במדעי הרוח והחברה (Nussbaum, 2003). כאן ראוי להזכיר את ההגות של אמרטייה סן (Sen) בנושא ואת גישת היכולות (capability) שהציע. לפי גישת היכולות, עלינו למדוד את איכות החיים במונחים של חירויות והזדמנויות "להיות" במצב מסוים (to be) או "לעשות" פעילות כלשהי (to do) שעשויים להסב לנו סיפוק או ערך (Sen, 1999). לגישה זו, פיתוח אנושי יוגדר כתהליך ההרחבה של חירויות והזדמנויות, ולכן הרחבה של היכולות שלנו: היכולת שלנו להיות במצב מסוים והיכולת שלנו לעשות פעילות כלשהי (Sen, 1990). הדרך הנכונה לחשוב על "יכולות", לפי סן, היא לשער מעין צבר של "תפקודים" (functionings). התפקודים האנושיים, או הדברים שאנשים עושים, נעים במדרג: מן הבסיסי, כמו למשל צריכת מזון, ועד המורכב - כמו למשל תרומה לחיים קהילתיים. גם גישת היכולות, שאותה אימץ ה־OECD, מדגישה את רב־הממדיות של איכות חיים (Alkire, 2002, 2010).

גישת היכולות של סן סוטה מן התלם התועלתני החרוש שהכלכלה הקלאסית הכשירה. היא טוענת שתועלת חומרית אינה ערובה מוחלטת לאיכות חיים. היא גורסת שאיכות חיים היא תופעה רב־ממדית. לעומת זאת בבחינת "אמצעי הייצור" (אם ניתן לכנותם כך) הדרושים

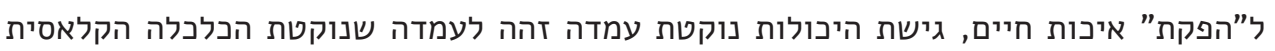
באמצעות פונקציית הייצור. חירויות, הזדמנויות, יכולות ותפקודי האדם תלויים תלות מוחלטת בגישה למשאבים מסוגים שונים (Sen, 1985). רובינס דקדק וטען שאיכות החיים תלויה לא רק במשאבים עצמם - מוחשיים ולא מוחשיים - אלא גם ביכולתנו להמיר את המשאבים הללו לתפקודים. יכולת זו, הוא טוען, נשענת על אמצעי המרה חברתיים, למשל מוסדות, Robeyns, ) ועל אמצעי המרה פרטיים, למשל תכונות אישיות, כמו גם על תנאים סביבתיים 2005). בין שמאמצים את גישת היכולות ובין שלא (סקירה זו אינה עוסקת במשמעות של 
איכות חיים אלא ביכולת לשמר רמה כלשהי של איכות חיים לאורך זמן), המסקנה העולה ממנה היא שאיכות חיים תלויה בבסיס המשאבים החברתי.

אם אנו בוחרים להביע את טענת הגישה בביטוי אלגברי, אלמנטרי ביותר, ואין כל הכרח לעשות זאת, אז בראי פונקציית הייצור, והדיונים הקצרים שערכנו כאן, עלינו להחליף את התוצר החומרי (או סך התוצרים החומריים) בביטוי שמייצג איכות חיים (W), וכן עלינו להוסיף אפשרות ל"צריכה ישירה" של מלאי הון מלבד ייצוג של מלאי הון בתפקידם כגורמי ייצור של טובין (Q).2' הפוקנצייה במשוואה זו מגלמת את תהליכי ההמרה של משאבים ליכולות ותפקודים.

$$
\mathrm{W}=f\left(\mathrm{Q}, \mathrm{K}_{\mathrm{H}}, \mathrm{K}_{\mathrm{S}}, \mathrm{K}_{\mathrm{C}}, \mathrm{K}_{\mathrm{E}}, \mathrm{K}_{\mathrm{N}}\right)
$$

כאשר

$$
\mathrm{Q}=f\left(\mathrm{~K}_{\mathrm{H}}, \mathrm{K}_{\mathrm{S}}, \mathrm{K}_{\mathrm{C}}, \mathrm{K}_{\mathrm{E}}, \mathrm{K}_{\mathrm{N}}\right)
$$

ככל שמחלקות ההון יצמחו, האפשרויות לממש צרכים ומאוויים במישרין (חשיפה למלאי הון) ובעקיפין (צריכה של מוצרים ושירותים) תגדלנה. אם מלאי ההון יידלדלו, תידרדר איכות החיים ובכלל זה רמת הרווחה החומרית. כלומר, איכות החיים תלויה תלות קטגורית במלאים של הון באופנים שונים, ישירים ועקיפים, ומלאי הון גם עשויים להשפיע זה על זה. הון ולא מוצרים גרידא, הון מסוגים שונים, מצבו, מאפייניו, כמותו, איכותו, פיזורו במרחב, נגישותו - הם שיקבעו את רמת איכות החיים. על כן התשובה לשאלת סקירה זו: "האם איכות החיים בישראל בת־קיימה?" צריכה להיבחן לפי גישה תאורטית ששמה את ההון במרכזה, היא גישת

ההון. 


\section{$\lambda$ \\ תאוריית גישת ההון לפיתוח ויתרונותיה}

בשנים האחרונות קנתה לה גישת ההון, בשמה המלא "תאוריית גישת ההון לקיימות" (capital (Stern, 1997) (theory approach for sustainable development מחקר ומדיניות כאחד. ה־OECD, שמוביל את המדידה של איכות חיים בעולם ומפתח שיטות להערכת מידת הקיימות של איכות החיים, אימץ את תאוריית גישת ההון זה מכבר. "שיפור איכות החיים לאורך זמן", לפי הארגון, "מותנה בניהול קפדני, במדידה ובהגנה על מלאי הון מסוגים שונים... הון כלכלי, הון טבעי, הון אנושי והון חברתי".22 בשנת 2009 קבעה הוועדה הכלכלית האירופית של האומות המאוחדות (UNECE) שלא ניתן לשפר את איכות החיים החברתית הכללית למשך זמן אם השיטות והאמצעים שמשמשים לכך פוגעים בבסיס המשאבים של החברה (הם מלאי הון) (UNECE/OECD/Eurostat, 2009). הטענה המרכזית של תאוריית גישת ההון היא שמדינות לאום, ובכלל זה חברות ומשקים לאומיים, חולשות על משאבים מטיפוסים שונים. משאבים אלו מכונים גם מלאי הון.23 בסיס המשאבים של מדינת הלאום, או מלאי ההון והעושר העומדים לרשותה, הם המאפשרים תהליכי פיתוח אנושי, שיפור בתנאי איכות החיים והרחבה של הזדמנויות הצריכה במובנה

הרחב ביותר.

תזת הגישה נשענת בין היתר על העיקרון שלפיו איכות חיים בת־קיימה מותנית בשמירה על רמה קבועה של הון לאורך זמן (Pearce \& Atkinson, 1992, 1993).24 כל קטגוריית הון - כלכלי, טבעי, אנושי, חברתי ותרבותי - עשויה קבוצת פריטים או מרכיבים. הספרות המדעית בתחום מכנה פריטים אלו "נכסים" או "נכסי הון". נכסים אלו עשויים להיות, כאמור, מוחשיים או לא מוחשיים, כלכליים או לא כלכליים, ניתנים לחליפין או לא (עוד על תכונות

אלו בהמשך).

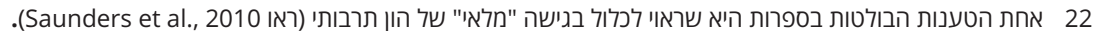

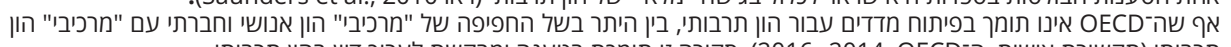

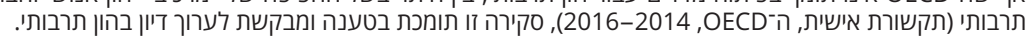

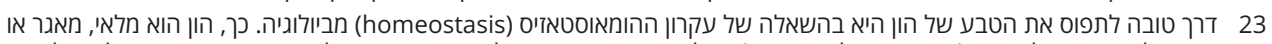
צבר של פריטים ואלמנטים (חומריים או לא חומריים) בעלי אופי הומאוסטטי. כלומר, פריטים או אלמנטים שנמצאים בתהליך של שיווי משקל דינמי עם סביבתם החיצונית; הם עוברים שינויים, ואף על פי כי כן הם יציבים דיים לאורך זמן, וניתן אפוא להבחין בהם בה בבהירות (שומרים על שלמות פנימית; (integrity). הם גמישים וישים

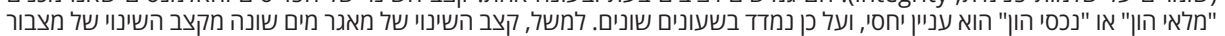
פחם, ושניהם שונים מקצב השינוי של "מלאי" הפטנטים, "מלאי" האמון הכללי בחברה נתונה, "מלאי" הרשתות החברתיות וכיוצא באלה. 24 עיקרון זה מרחיב את עקרון "הארטוויק־סולו" (Hartwick-Solow), שלפיו רמת הרווחה החברתית תלויה ברמה בלתי פוחתת של צריכה

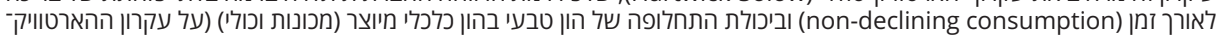
סולו ראו Solow, 1986; Hartwick, 1990; Hartwick, 1978a; Hartwick, 1977; Solow, 1986 
במקרים מסוימים מדידתו של מצב הנכסים תהיה פיזית או תיאורית (מדדי כמות ואיכות בסרגלים מקובלים). במקרים אחרים תתאפשר המדידה של נכסים בשיטות מוניטריות (תמחור ושווי). כמו כן נכסים מסוג ספציפי יצריכו מדדים סובייקטיביים (למשל "אמון כללי" במחלקת ההון החברתי), ואילו נכסים מסוג אחר יצריכו מדדים "אובייקטיביים" (למשל "תוחלת חיים בריאים" במחלקת הון אנושי).

לטענת תאוריית גישת ההון, הריבונות החוקית על כל מלאי (ריבונות ציבורית או פרטית) ומימושה של ריבונות זו - בתהליכים של קבלת החלטות ויישומן (מדידת הון, הקצאתו, ייצורו, צריכתו, החלפתו או השקעה בו [Dixit et al., 1980]) - עשויה לשנות הן את מצב המלאי והן את פיזורו במרחב ובזמן, ובכך לשנות את תנאי החיים הקולקטיביים. לשיטה זו, כל הסדר פוליטי הוא חוויה של הקצאת הון, עם וקטורים שמשתרעים אל מתחם עתידי שבו מתפקדים הדורות הבאים, ובו האוויר מזוהם או לא, המים ראויים לשתייה או שאינם, ורמת האמון הכללית בחברה גבוהה או נמוכה מבעבר. קיימות כמה דרכים להשפיע על כמות המלאי ואיכותו ועל פיזורו בזמן ובמרחב, אולם על פי רוב מדינת הלאום תשנה את מצב המלאי באמצעות שימוש ב־(צריכה של) מלאים שונים, החלפתם במלאים אחרים או השקעה בהם. מבחינה פוזיטיבית אפשר שניהול נכסי הון מסוימים יהיה מחוץ להישג ידה של ה"מדינה", ואפשר גם שמצב זה צריך להיות נורמטיבי. נדמה שעל הדיון בהון תרבותי לעסוק בכך. גם אם הפרשנות הפלורליסטית שאנו נוקטים עבור המונח "הון" (הון טבעי, הון תרבותי והון חברתי) דוחפת את הגישה אל מחוץ לשדה הכלכלי, העובדה שמוצאה של גישת ההון הוא ברעיון פונקציית הייצור עשויה לסייע לנו. המקורות הכלכליים של המונח "הון" והטרמינולוגיה הנלווית למונח (למשל "קניין", "חליפין", "פחת", "תשואה" בצורת "רנטה" או "ריבית" [Hamilton \& Hartwick, 2005]) מציעים לנו כלים אנליטיים שונים ללמוד, ובמידת הצורך לנהל, סוגים של הון כדי שאלו יתמכו באיכות חיים מתמשכת. לשון אחר, אף שניתן להגדיר את תאוריית גישת ההון "תאוריית כלאיים", אפשר שמונחים כמו מלאי, זרם, השקעה, צריכה, תחליפיות או עלות ההזדמנות (opportunity cost),25 מונחים שמיושמים

25 המושג "עלות ההזמנות", המכונה בתאוריה הכלכלית גם "עלות אלטרנטיבית" (alternative cost), נועד לסייע בהקצאה של אמצעי

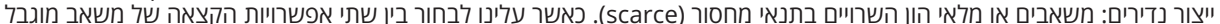
(אפשרות א ואפשרות ב), העלות של האלטרנטיבה הנבחרת (המחיר של אפשרות א) מתומחרת באמצעות הרווחים הפוטנציאיאליים

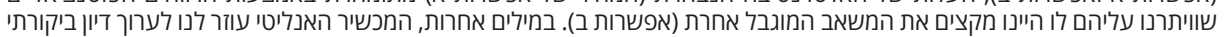

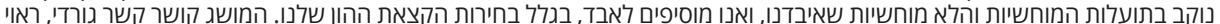

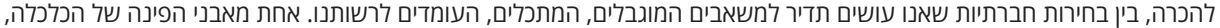

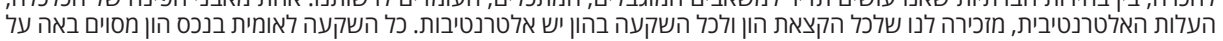

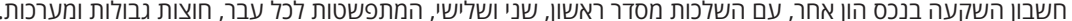

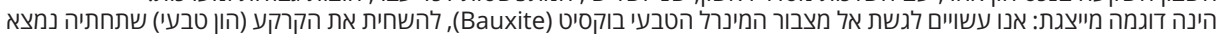

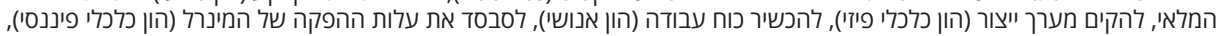

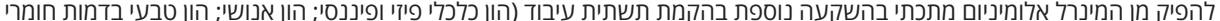
בנייה; בטון וברזל), לתפעל את התשתית (בשימוש למשל בדלקים מסוגים שונים), לייצא את המתכת ולקלוט תמלוגיוגים אל קופת המדיני בינה

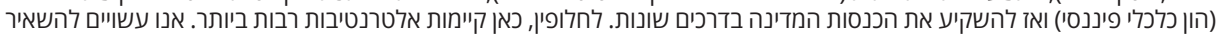

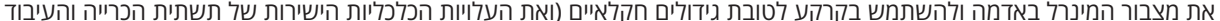
ואת העלויות הכלכליות העקיפות של שימוש בדלקים וכימיקלים מזהמים להשקיע בשיפוים השיר התנאים של מערכת הבריאות הציבורית, או להקים מרכז תרבות, מוזאון ותיאטרון). הדיון הזה מתחיל מחדש אם אנו כבר מחזיקים במלאי מוגבל של אלומיניום מתכתי וצרי הכיכים לבחור כיצד להשתמש בו ועבור י"צור של איזו סחורה אלטרנטיבית. 
כלאחר יד במדע הכלכלה, יועילו לנו בדיון בהון טבעי, אנושי, חברתי ותרבותי. זו המשמעות של יצירת אותו מרחב תאורטי מאוחד - מתחם שמזמין אליו קהילות שונות כדי ליישב

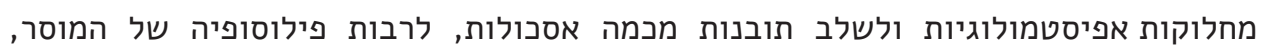
פילוסופיה פוליטית, אנתרופולוגיה, סוציולוגיה, מדעי המדינה, כלכלה, דמוגרפיה, אקולוגיה ומדעי הסביבה, תזונה, אפידימיולוגיה וגאוגרפיה.

\section{מיתרונות התאוריה}

תאוריית גישת ההון ניחנה בשלוש תכונות מועילות: אינטואיטיביות, אופרטיביות ותמיכה רחבה: - n

• אינטואיטיביות: תאוריית גישת ההון היא אינטואיטיבית ומאפשרת להבין שינויים במלאי הון ללא הכשרה מיוחדת. סוויני וסטרמן הציעו את המטאפורה של דינמיקת אמבטיה כדי לתאר את הכוחות המעורבים בהתפתחות של מלאי לאורך זמן (Bathtub Dynamics) (Sweeney \& Sterman, 2000). במודל האמבטיה כמותם ואיכותם של המים באמבט

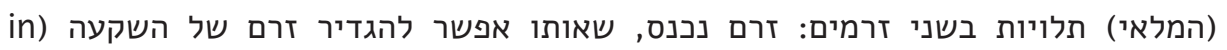
(flow), וזרם יוצא, של ניקוז, שאותו אפשר להגדיר זרם של צריכה (out flow) המטאפורה מחייבת אותנו לסרטט גבולות סביב המערכת שמעבר להם איננו מבצעים חקירה. במקרה זה אנו עוסקים באמבט, בזרם הנכנס לאמבט ובזרם היוצא מן האמבט. אין ענייננו במקור המים (מניין מגיעים) או ביעד הסופי של המים לאחר שנוקזו (אנה זורמים). שניהם חיצוניים לאמבט. מובן שגבולות אלו הם מלאכותיים ומסייעים לנו לפשט את המודל ולהתמקד במלאי המים באמבט. מיקוד זה מסייע לנו בתורו לבחור יחידות מדידה ראויות, למשל נפח, הרכב מינרלי, רמת חומציות או אלקליניות, טמפרטורה וכולי. כמו כן לפי קצב המים הזורמים אל תוך האמבט ולפי קצב המים הזורמים אל מחוץ לאמבט אנו יכולים להקיש על מצב המלאי בעתיד ולקבוע את קצב התחדשות המלאי (הפער בין זרם נכנס לזרם יוצא ליחידת זמן). אנו יכולים לעמוד על עוצמת התלות בין הזרמים, שכן הזרם היוצא

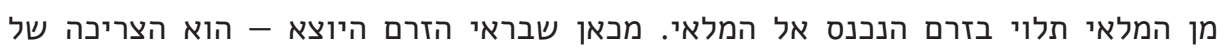

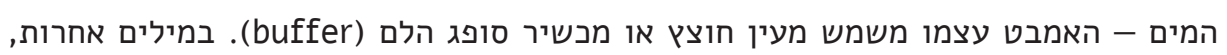

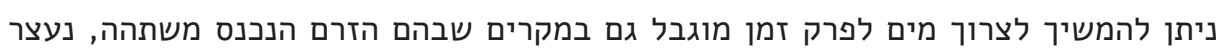
או חדל מלהתקיים. אנו יכולים לזהות עיכובים במערכת, למשל הזמן שחולף מהנקודה

שסובבנו את ברז הזרם הנכנס ועד הרגע שבו המים מתחילים לזרום אל תוך האמבט. 
רשימה זו, של הבחנות אינטואיטיביות, היא חלקית בלבד. אנו יכולים להקשות ולשאול: האם האמבט, בהיותו "מערכת פתוחה", חשוף לתופעות תרמודינמיות כלשהן? או כשאנו מותירים אותם ללא השגחה, האם מי האמבט מתאדים? אלו אינן קושיות תאורטיות גרידא. אם איכות החיים שלנו תלויה בצריכה קבועה של מי האמבט (המדומיין) - לשתייה, לסניטציה, לרחצה, להשקיית שדות או לקירור טורבינות - אז השלכות הפרמטרים השונים הן הרות גורל. עוד עלינו לשאול אם הנחות מודל האמבט תקפות לכל מלאי הון. האם ייתכן

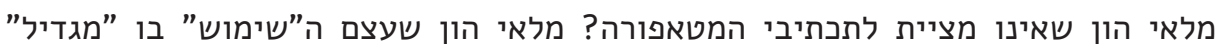
אותו? דיון באפשרות זו נערך בהמשך. יתרון נוסף של תאוריית גישת ההון, שהוא נגזרת של מטאפורת האמבט ומידת האינטואיטיביות שבה התאוריה מתאפיינת, היא היכולת "לתקשר" או להעביר מסרים על שינויים במלאי הון, על טבעה של דינמיקת מלאי זרם, על תלות בין זרמים או על השהיות וכולי - לציבור שלא הוטבל במימי התאוריה, וכל זאת בקלות יחסית ובאמצעות אילוסטרציות. רמת האינטואיטיביות שתאוריית גישת ההון מציעה - איכות שהודגשה זה מכבר במסגרת המאמץ הלאומי להגדיר ולמדוד איכות חיים ולנסח את התנאים הנדרשים לשמור על רמתה לאורך זמן (למן שנת 2012) (ממשלת ישראל, 2016; הלמ"ס, 2018, 2019) - עשויה לסייע למדינאים ולעובדי ממשל "לפזר את הערפל הטרמינולוגי האופף

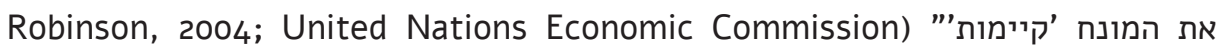
.(for Europe, 2015 אופרטיביות: התאוריה מציעה מרשם אופרטיבי ממוקד: היא מדגישה מה יש לעשות אם מעוניינים לשמור על רמת צריכה מסוימת; על סטנדרטים ספציפיים של רווחה או על איכות חיים כללית. היא מעמידה סוללה של כלים לברור מתוכם את ההולמים ביותר לניתוח כל מחלקה ומחלקה של הון ולמיפוי הקשרים בתוך מחלקות הון ובין מחלקות הון.27 בין שאנו דנים במדיניות מבוססת־ראיות ובין שאנו דנים בניהול ציבורי מבוסס־מחוונים (indicators), תאוריית גישת ההון מציעה פריזמה מצומצמת דייה לבחון אם איכות החיים בת־קיימה: יש למדוד ולנהל את מצב חמש הקטגוריות של "אמצעי הייצור של איכות חיים". על כך העיר דסגופטה: "על מנת שמערכת מדדים תשמש בתהליכי קבלת החלטות, חזקה עליה שהיא תהיה מצומצמת" (Dasgupta, 2001). • תמיכה רחבה: גישת ההון זוכה לתמיכה רחבה חרף העובדה שהשדה התאורטי שבו הגישה מתהווה איננו שלם ולמרות מחלוקות מתדולוגיות שעוד יש ליישב וכלים אנליטיים שיש Smith et al., 2001;) לבחור. בין היתר תאוריית גישת ההון זוכה לתמיכה מוסדית UNECE/OECD/Eurostat, 2008; Hall et al., 2010; UNECE/Eurostat/OECD Task

27 לצורך המחשה, אם ברצוננו להתערב בדינמיקת מלאי זרם של הון מסוג מסוים, למשל כדי לוודא שהזרם היוצא אינו פוחת לאורך זמן,

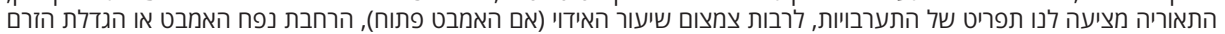

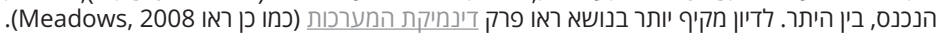


Victor, 1991; Pearce \&) ומדעית בין־תחומית (Force, 2011; Rinne et al., 2013 Atkinson, 1993; Berkes \& Folke, 1994; Stern, 1997; Ayres et al., 2001; Ekins et al., 2003; Lehtonen, 2004; Ruta \& Hamilton, 2007; Stiglitz et al., 2009; 2015 זו היא אנתולוגיה של כתבים ומחקרים שעליה ניתן להישען על מנת לפתח את התאוריה הלאה, אל השדה המוסדי־יישומי: להפוך אותה לפרויקט מחקר יישומי. נדמה שתמיכה זו נובעת מהעוצמה האונטולוגית והסיבתית של התאוריה (כלומר היא עומדת גם במבחנים פוסט־אינטואיטיביים): התיאור ההוליסטי שהיא מציעה לגורמים המחוללים והמניעים של איכות חיים והיכולת להשליך תיאור זה על הקשרים לאומיים שונים (האיכות האוניברסלית שלה נדונה לעיל) (שטיגליץ, 2017; פיטוסי, 2017; דסגופטה, 2018). לפני שאנו מתקדמים לאמץ את הגישה ולהמליץ על דרך הפעלתה בהקשר הישראלי, כלומר לגזור ממנה מרשם המלצות לניהול בסיס המשאבים הלאומי למען איכות חיים מתמשכת, יש לערוך כמה הבחנות ולהתייחס לכמה שאלות שיש לתת עליהן את הדעת. למשל, יש להבחין בעובדה שהון הוא אינו אובייקט הומוגני, העשוי מקשה אחת, ועל כן עלינו לבחון מאילו פריטים הוא עשוי. שנית, עלינו לעיין עיון נוסף, מעמיק יותר, במרכיבים של כל מחלקת הון. עלינו להוסיף ולעמוד על הפערים המהותיים בטבעם של מלאי הון מסוגים שונים, וכיצד הם מגיבים לניצול ולשימוש. דיון זה בטבע הייחודי של הון מסוגים שונים מסמן את גבול המטאפורה של פונקציית הייצור. הבחנות ושאלות אלו נדונות בפרקים הבאים. 


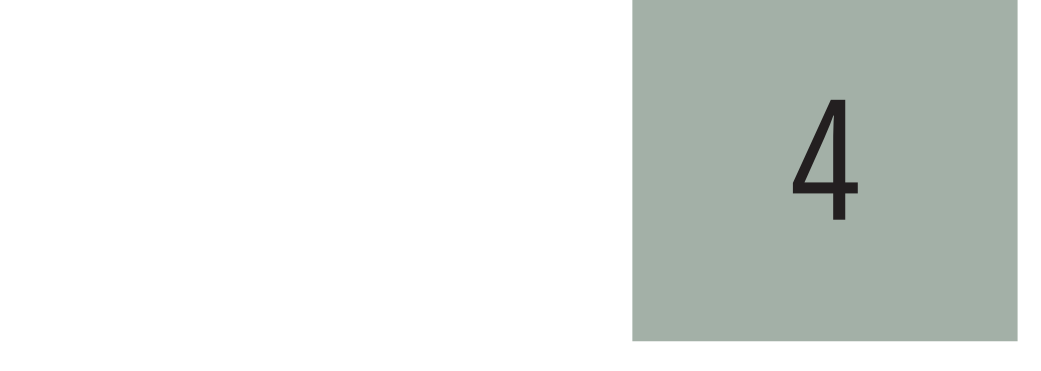

\section{סוגים של הון ושל נכסי הון}

N

\section{הבחנה בין הון ובין נכסי הון}

השכל הישר אינו מאפשר לנו לחשוב על "הון" כעל ישות הומוגנית. גם במקרה של פוקנציית ייצור פשטנית אין דין מכונה אחת כדין מכונה אחרת.28 למשל, בהקשר של ההון הטבעי, בפי שהוצג קודם לכן, הבחינו הכלכלנים הקלאסיים ג'ונסון וטאוסיג, ש"תשומות טבעיות בתהליכי ייצור", קרי מלאי ההון הטבעי, עשויות לכלול "אדמה" ו"גורמים טבעיים" שונים.

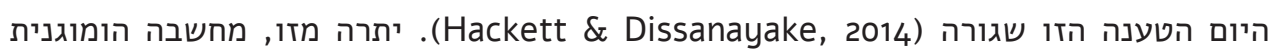
על מחלקות ההון עשויה להוביל למבוי סתום מתודולוגי ומעשי. בהיבט המתודולוגי ניטור ומדידה של סוגי ההון השונים צריכה להיעשות לפי מרכיביהם משום שאין דרך מוסכמת להמציא מדד מצרפי (אגרגטיבי) יחיד עבור סך נכסי ההון. הדבר נכון ל"הגורמים הטבעיים" ול"התופעות הטבעיות" הכלולים במחלקת ההון הטבעי והתורמים

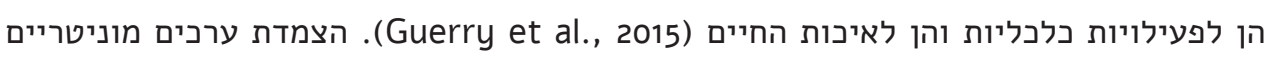

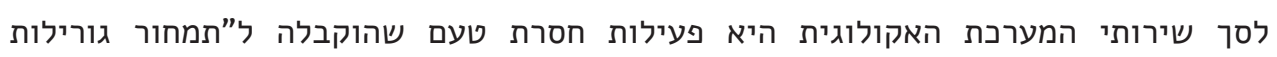
בערפל" (Fanny et al., 2015). זה נכון גם להון אנושי, חברתי ותרבותי, שרכיביהם עשויים

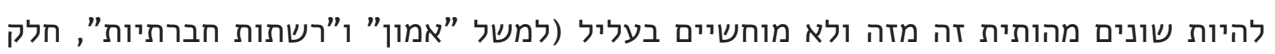

ממרכיביו של ההון החברתי).

בהיבט המעשי, אין שום ערך מיוחד עבור הריבון, בכובעו כמנהל המשק הלאומי, או הכַּלכַּל הראשי רמי

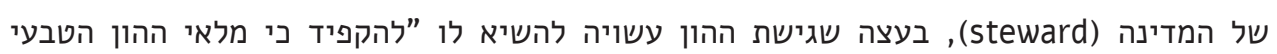
אינו פוחת לאורך זמן". כדי לעמוד במשימה זו על הריבון להבין מהו ההון הטבעי ומה הוא כולל. 
כאמור, הספרות מכנה לא אחת את הרכיבים של כל מחלקת הון בכינוי "נכסים" או "נכסי הון" Deutsch et al., 2003; Bryan et al., 2010; Bowman \& Swart, 2007; Magdol) הessel, 2003; Uphoff, 2000; Throsby, 1999 קבוע, והמסומנים ("המשמעויות של נכסים") משתנים. אחת ממטרות סקירה זו היא לנוע לעבר אחידות בשימוש במונח "נכס" ולהניח תשתית לטקסונומיה אוניברסלית עתידית ושלמה (הטקסונומיה של תאוריית גישת ההון עודנה מתהווה).29 כאן משרתים אותנו מדעי הטבע.30 סקירה זו מאמצת את סוג הטקסונומיה המדרגית המשמשת במיון עולם הטבע (המדרג של לינאוס או הטקסונומיה הלינאית). כך, "נכס הון", או בקיצור "נכס", יבטא בסקירה זו את "המדרגה הבאה" בהייררכייה של גישת ההון. דהיינו: מערכת האמצעים התורמים לאיכות החיים (מערכת גורמי הייצור) כוללת את כל מחלקות ההון. מחלקת הון כוללת את כל סדרת נכסי ההון. נכסי הון יהיו דומים בתכונותיהם, עליהם לתרום לרמת איכות החיים (להיות בעלי ערך) ובאותה רמת הפשטה (על כולם לבטא תכונות של מלאי, מאגר או צבר). סיווג זה אינו שלם, ואין זה מתפקידה של סקירה זו להשלימו. הוא נועד, בשלב זה, להמחשה.

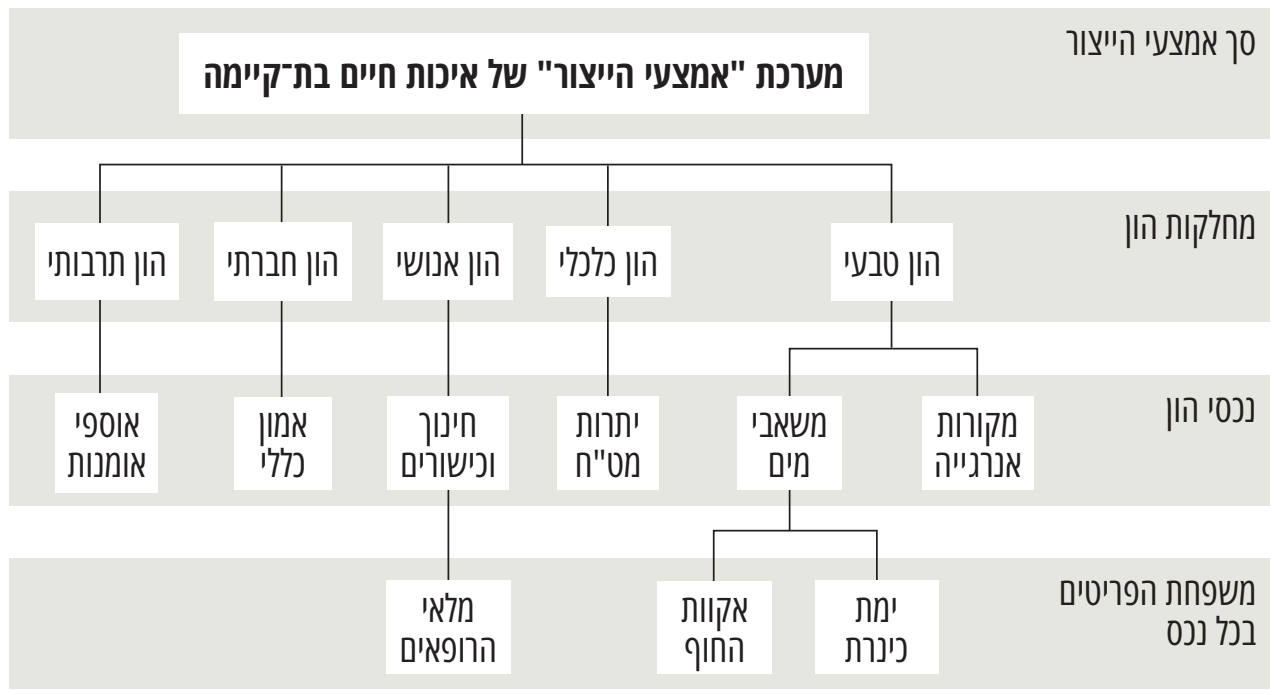

לדוגמה, מחלקת ההון הטבעי תכלול סדרה של נכסי הון. משאבי מים יהיו נכס הון טבעי אחד שיכלול מאגרי מים נפרדים של ימת כינרת או אקוויפר החוף, במקרה הישראלי. מקורות

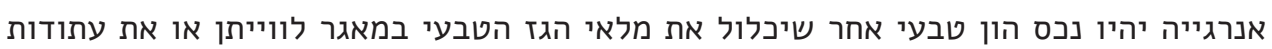
פצלי השמן בחבל עדולם. במחלקת ההון האנושי ייצגו חינוך וכישורים נכס הון או ממד הוני

בעל תכונות דומות יחסית שיכלול את משפחת הרופאים ומשפחת המהנדסים, בין היתר.31

29 למשל, נוסף על המבקשים להפריד "הון תרבותי" מסוגים אחרים של הון, יש גם הקוראים למחלקה שישית של "הון מוסדי" (ראו לדוגמה:

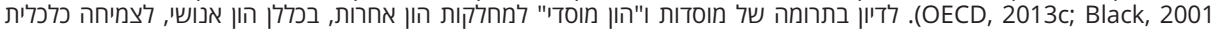

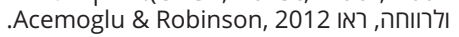

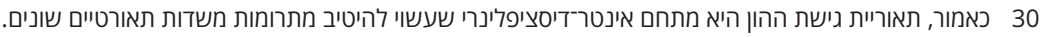
31 כאמור בעבודות קודמות, אין תמימות דעים באשר לרשימת הנכסים המרכיבים כל קבוצה (ראו ממשלת ישראל, 2016). 
ייתכן שבמקרים מסוימים יצווה עלינו להאיר את "המדרגה הבאה" ולעמוד על ההבדלים שבין המרכיבים של כל נכס ועל התרומה היחסית של מרכיבים אלו לכושר השמירה על רמת איכות החיים. לדוגמה, ענפי חינוך שונים ומערכות כישורים שונות יחזיקו בפוטנציאל שונה לשמור על איכות החיים לאורך זמן.

\section{]}

\section{הבחנה בין סוגים של הון}

ביסודה של גישת ההון מונחת אפוא הטענה שמחולליה של איכות חיים הם מלאים של נכסי הון. בהינתן גישה לנכסי ההון הללו, תושבי המדינה יוכלו להפיק מהם ערך. משמעות הדבר היא שככל שנכסים אלו יוסיפו להתקיים ולהניב תועלות וערכים, כך רמתה של איכות החיים הכללית תישמר. הגישה נוטה לסווג את נכסי ההון לחמש קטגוריות, או מחלקות, הון: הון כלכלי, הון טבעי,

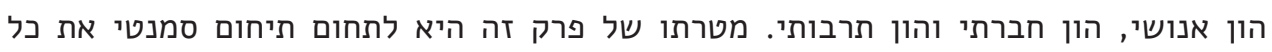
אחת מחמש מחלקות ההון. עם זאת עבודת המשך נדרשת לצורך זיהוי ומיפוי של נכסי ההון החיוניים ביותר בכל מחלקת הון. ראוי להדגיש שהתיחום אינו סופי: נכס הון שמוקם במחלקה אחת עשוי, לאחר מחשבה נוספת, להירשם במחלקה אחרת. כמו כן תיתכן חפיפה בין מחלקות

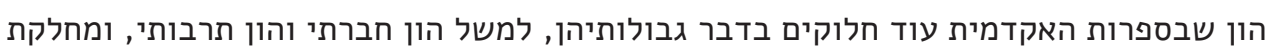
הון נוספת המכונה "מלאי הידע" (Matson et al., 2016) (knowledge capital). אף שיש אתגר במניעת חפיפה בין מלאי ההון לנכסי ההון בעת מיונם לחמש מחלקות ההון, אין להפריז בחשיבותו של אתגר זה, שכן ניתן להתמודד איתו בבירור ביקורתי חוזר מעת לעת. תחת זאת יש להישמר מפגמים שעלולים ליפול בזיהוי נכסים קריטיים, ובעיקר שני סוגים של בשלים (Neyman \& Pearson, 1928): אנו עלולים להניח שנכס הון הוא "קריטי" אף שהוא אינו קריטי כלל ועיקר (false positive error), או שאנו עלולים להניח שנכס הון אינו "קריטי" אף שהוא כזה (false negative error). במקרה השני הקצאת המשאבים הלאומית לניטור, לאומדן, לניהול ולהגנה תפסח על גורם מחולל חיוני של איכות החיים הציבורית, על Lל

כל ההשלכות הנלוות לכך. 
יש להבחין בין שני סוגים של הון כלכלי: הון כלכלי מיוצר והון כלכלי פיננסי. הראשון כולל נכסים פיזיים, למשל מערכות תשתית ומכונות, והשני נכסים לא מוחשיים, כגון פיקדונות ואיגרות חוב (Smith et al., 2001). דיסציפלינות אחדות נוגעות בניהול מלאים אלו, ויש לציין במיוחד את הכלכלה, את המשפטים ואת ענפי ההנדסה, ועוד כמה דיסציפלינות שעשויות לתרום לניהולו, ובכללן גאוגרפיה ואקולוגיה תעשייתית.32 נכסי הון כלכלי מיוצר תורמים סימולטנית, במישרין ובעקיפין, לאיכות החיים באמצעות הספקה של תשתיות, חומרי בריאות ושירותי בריאות, חינוך, תחבורה, אנרגייה, מים ומזון, בין היתר. די להיזכר בתפקיד שתשתיות הביוב שיחקו בשיפור התברואה העירונית, התנאים הסניטריים ובמניעת תחלואה (Brown et al., 2009). לאחרונה נשמעות קריאות (Andrews \& Criscuolo, 2013) לייחד מקום לקבוצת נכסים לא מוחשיים נוספת תחת הכותרת "נכסי ידע" (knowledge-based capital). הטענה החוזרת היא שהמציאות הכלכלית מעידה על השקעה לאומית בנכסים אלו ועל חשיבותם של נכסים אלו לצמיחה (OECD, 2013b; Van Ark et al., 2009). עיון קצר בספרות מראה כי נכסי ידע כוללים, בעיקר, מידע ממוחשב בצורת אלגוריתמים ומערכת התוכנות (software) הניצבת על אלגוריתמים אלו וכן תת־קטגוריה של "קניין חדשני" (innovative property) Corrado, Hulten \& Sichel, 2009;) הנובעת מתהליכי מחקר ופיתוח מדעיים ותעשייתיים Corrado, Haskel, \& Jona-Lasinio, 2017; Andrews \& Criscuolo, 2013 ואחרים (Matson et al., 2016) טענו שמלאי הידע מצדיק הקמה של מחלקת הון נוספת, שאותה הם כינו "הון ידע" (knowledge capital). מחלקת הון זו תכלול ידע רעיוני־תאורטי, עובדתי ומעשי־יישומי. נכסי הון אלו מוגדרים "טובין לא מוחשיים". חלקם מוגדרים "מוצרים ציבוריים", ואילו על אחרים חלות זכויות יוצרים. ניתן להטמיע את הידע בפונקציות ייצור שונות, למטרות שונות. הספרות מזהה שתהליכים של התיישנות טכנולוגית גורעים ממלאי הון הידע של החברה, ושתהליכים אבולוציוניים עלולים גם הם לתרום להידלדלות מלאי הידע, למשל בתהליכים של פיתוח עמידות לאנטיביוטיקה אצל חיידקים (Baym et al., 2016). לפיכך השקעה במחקר ופיתוח היא הכרחית להרחבת מלאי הידע. סקירה זו אינה מוצאת את הטענה למחלקת הון נפרדת ראויה. ידע, מטבעו, גלום בנכסי הון שונים. כאשר הוא ידע תאורטי, נמצא אותו בהון תרבותי. כאשר הוא ידע יישומי, נמצא אותו במחלקת הון כלכלי. כאשר הוא מוטמע באוכלוסייה, נמצא אותו בצורת "השכלה" במחלקת ההון האנושי. 
המוסדות הבין־לאומיים אשר הציעו מסגרת מדידה לנכסי ההון הטבעי (מערכת החשבונות הכלכלית סביבתית המשולבת) קבעו כי מחלקת הון זו מתייחסת לסך הגורמים הטבעיים והתופעות הטבעיות אשר מרכיבים את הסביבה הביו־פיזיקלית ותורמים תרומה מכרעת לפעילות חברתית (United Nations, European Commission, International Monetary ח Fund, OECD, World Bank, 2003 משאבי הטבע ואת המערכות האקולוגיות המספקות ערב רב של חומרי גלם ושירותים, לרבות מים, מזון ומינרלים, שירותי טיהור אוויר ומים ופירוק פסולת, שירותי שימור מגוון המינים הביולוגי ושירותי תרבות הכוללים השראה והנאה בלתי אמצעית מן הסביבה הטבעית. Daily, 1997;) נכסי ההון מעלים תרומה חיונית הן לעצם הקיום האנושי והן לאיכות החיים (Costanza et al., 1997 הארץ, מדעי האטמוספרה, גאולוגיה, הידרולוגיה, אוקיינוגרפיה, מדעי הקרקע, גאוגרפיה, אקולוגיה, כלכלה סביבתית וכלכלת משאבי טבע ויתר תת־הענפים המתפצלים ממדעי הסביבה (למשל מדעי הצמח וזואולוגיה). מקצת נכסי ההון הטבעי עוברים תהליכים של אקונומיזציה בפשטות יחסית: כרייה של עפרת מחצב מעורקו או קטיף של פרי מעצו, ושילוח אל תוך השוק הכלכלי, מקום שבו הם שמים משמשים סחורה או דבר חליפין וזוכים, בתמורה, למחיר. נכסי הון אחרים, אם מקובלת עלינו התווית "נכס הון" עבור למשל "מלאי האוויר", חיוניים לא פחות לאיכות החיים, אולם נצרכים באופן בלתי אמצעי, ללא תיווך השוק. בהיעדר משטר קנייני או מחיר לווסת את השימוש

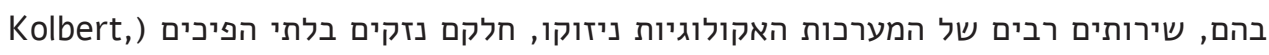
2014; Barnosky et al., 2011 אנתרופוצנטרית "שירותי מערכת אקולוגית", כמו האבקה, חיוניות להתפתחות חברת הצמחים,

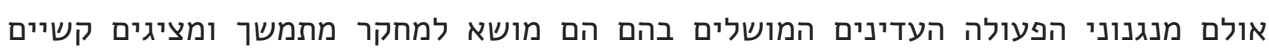
ניכרים לתמחור ישיר (Allsopp et al., 2008).

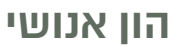

לפי ה־OECD, הון אנושי מבטא את מלאי הידע והמיומנויות הטבועים באדם הנובעים מחינוך והכשרה, פורמליים וא־פורמליים, ומאפשרים תהליכים של פיתוח אנושי ורווחה אישית, קוקלטיבית, כלכלית וחברתית (OECD, 1998, 2001). המשגה זו של הארגון ניצבת על יסודות Schultz, 1961; Becker, 1962,) תאורטיים שהונחו כבר בשנות השישים של המאה העשרים 2009). השקעה במלאי הון זה, כך לפי הספרות (Gemmell, 1996; Hatch \& Dyer, 2004), 


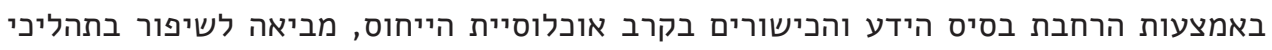
ייצור כלכלי, לצמיחה ולהשגת יתרון תחרותי בשוק. יתר על כן, לפי תפיסתם של שטיגליץ Stiglitz) ואחרים, הסקירה מכלילה בהון האנושי גם את התפקודים הבריאותיים של הפרט (et al., 2009; Mirowsky \& Ross, 1998 ושותפיו למסקנה שיש להביא בחשבון היבטי בריאות פיזית ונפשית של האדם כשחושבים על השקעה ו"שימוש" בהון אנושי בתהליכי פיתוח, וכשאנו דנים בתרומת ההון האנושי לאיכות Becker, 2007; Victora et al.,) החיים. עמדה זו משקפת הסכמה מחקרית רחבה בתחום 2009 את הבולטות שבהן, עלינו למנות את אלה: הדמוגרפיה, בריאות הציבור ומדעי הרפואה, גרונטולוגיה, חינוך, כלכלת חינוך, כלכלת בריאות וגאוגרפיה.

להון אנושי שלוש פנים: גודל האוכלוסייה ומבנָּה (התפלגות מגדרית, צורתו של "הפעמון הדמוגרפי"), בריאות נפשית ופיזית של האוכלוסייה (תוחלת חיים בריאה לנפש) וחינוך וידע (Cohen, 2010). בחינת ההון האנושי צריכה להיעשות באמצעות בחינת מלאי כללי שלו (ההשכלה הממוצעת לאדם) ובד בבד של תת־מלאים פרטניים שלו - אותם תת־מלאים שבצירוף גורמי ייצור אחרים (למשל בתי חולים וציוד רפואי) מספקים שירותים חיוניים לאיכות החיים, במקרה זה שירותי רפואה.34 לשיטה זו, מלאי הרופאים באוכלוסייה, מלאי המהנדסים באוכלוסייה ומלאי המורים באוכלוסייה יהיו "תת־מלאים קריטיים". חשוב להבחין שהון אנושי מחזיק בתכונה כפולה באשר לאיכות החיים. חינוך או מלאי הכישורים והמיומנויות באוכלוסייה, המוגדרים כאן ממדים של מלאי ההון, כלומר "גורמי ייצור" של איכות חיים, הם גם ממדים של איכות החיים עצמה. במבט ראשון ניתן למצוא אותם בשני צידי הרעיון של פונקציית הייצור (Matson et al., 2016). דוגמה נוספת היא בריאות: בריאות אומנם מאפשרת לאדם "לייצר" איכות חיים טובה יותר, אך הבריאות עצמה היא חלק מאיכות חייו. כפילות זו נובעת ממקומם הכפול של אנשים בפונקציית הייצור. אשר לתהליכי ייצור, אנשים עשויים להחליף, בכל זמן נתון, בין כובע "יצרני איכות חיים" לכובע "צרכני איכות חיים". בנקודת זמן אחת, האדם יכול להיות מעורב בתהליך ייצור כלשהו, אך בנקודת זמן אחרת, מחוץ לשעות עבודתו, למשל, הוא יכול לפעול כ"צרכן" הנהנה מתהליכי הייצור בחברה. לכן השקעה במלאי הון זה תורמת סימולטנית לשני צידי המשוואה.

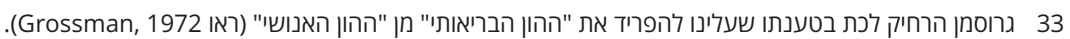

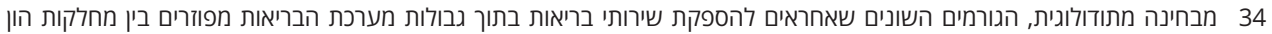

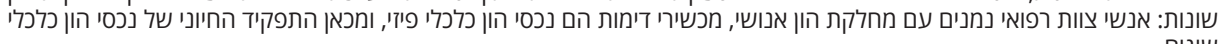


הון חברתי מתאר את התכונות של קהילות אנושיות, מה טיבם ועוצמתם של הקשרים בין חברי קהילה כלשהי (עד כמה רשתות קהילתיות מלוכדות; bonding social capital), אם הקהילה עשויה קהילות משנה, ואם כן, מהו אופי הקשרים בין חברי קהילות המשנה (אם מתוחים גשרים בין קהילות שונות - bridging social capital), וכיצד מערכות היחסים הקהילתיות ממוסדות: על בסיס אילו ערכים משותפים ולפי אילו נורמות וחוקים הרשת הקהילתית מתנהלת. לשון אחר, ההון החברתי נועד לבטא את עצם היחסים בין פרטים בחברה, את איכות היחסים כפי שאלו משתקפים למשל ברמת האמון ההדדי וכן את המוסדות אשר מסדירים את האינטראקציות בין הפרטים בחברה כפי שאלו מבוטאות בנורמות ובחוקים בין היתר.35 בכך הסדרים מוסדיים, כפי שיש לדון בהם בראי ההון החברתי, הם אוסף, או צבר, של חוקים פורמליים ולא פורמליים. אחת התכונות הבולטות במלאי הון זה היא "אמון". התרומה של אמון לרמת הרווחה החומרית נדונה בשנים האחרונות ביתר שאת, והובחן כי אינטראקציות חיוביות בין אנשים יוצרות אמון

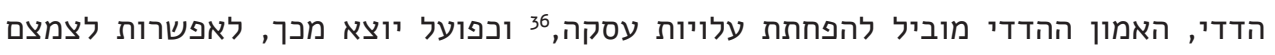
רגולציה של השווקים (Aghion et al., 2009). אמון הדדי מסייע אפוא למערכת הכלכלית לתפקד ביעילות (Arrow, 1972; Halpern, 1999; Algan \& Cahuc, 2010) כאמור בעבודות קודמות בתחום בישראל (ממשלת ישראל, 2016), ההון החברתי משפיע גם

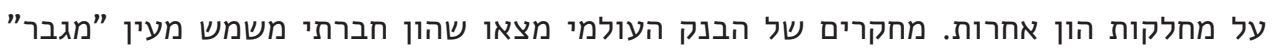
Grootaert, 1997; Grootaert \& van Bastelaer,) להשקעה בנכסי הון שונים (amplifier) 2001). בהקשר של תרומה לידע - בין שזה נמנה עם "נכסי ידע תרבותי" ובין שנמנה עם "נכסי ידע כלכלי" - מחקרים נוספים העידו שרמה גבוהה של אמון הדדי בין מוסדות אקדמיה Freeman \& Luc,) ופירמות, למשל, מזרזת את היצירה, את ההעברה ואת ההטמעה של ידע 2000). עוד נטען כי עוצמת הקשרים החברתיים, אופי הרשתות ורמת האמון בין פרטים מעודדים חדשנות תאורטית ומעשית. לונדבאל הראה כי רשתות חדשנות לאומיות תלויות בהון חברתי איכותי (Lundvall, 1992; Lundvall et al., 2001). חרף החשיבות המכרעת של ההון החברתי למפעל הפיתוח האנושי הופעתו של המונח בספרות

35 המונח "מוסד", שהוא מרכזי בנושא ההון החברתי, ניתן לפירושים אחדים, ונראה כי נקודת המבט של ההון החברתי תובעת לאמץ

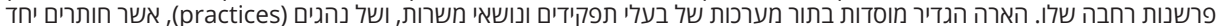

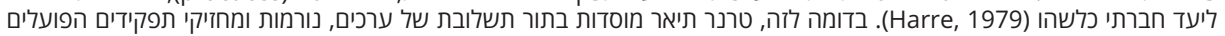

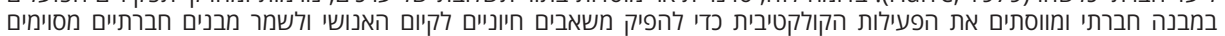
בסביבתם (Turner, 1997).

36 עלות עסקה מבטאת את העלות הכרוכה בביצוע החלפה של נכס כלכלי אחד בנכס כלכלי ניכלי אחר, או במסגרת גישת ההון: בנכס ממחלקת

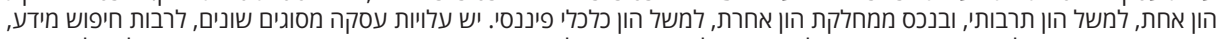

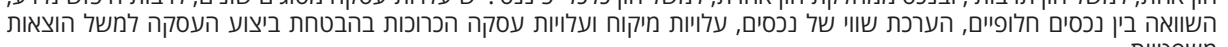


האקדמית איחרה להגיע, והבחינה הקפדנית של תרומתו לתהליכי פיתוח בר־קיימה השתהתה Healy \& Côté, 2001; Lehtonen, 2004; Rydin \& Holman,) עד המאה העשרים ואחת 2004; Dale \& Newman, 2008 כנזכר לעיל, בורדייה הציע אנליזה של המונח בהשוואה להון כלכלי ולהון תרבותי. בשנות התשעים של המאה העשרים התייחס רוברט פטנאם להון חברתי בתור "חומר הסיכה" החיוני לתפקוד חברתי, ובאמצעות מקרי מבחן הדגים את חשיבותו לאיכות החיים הכללית (Putnam, 1993, 1955).38 מלבד חוקרים אלה, מחקר ההון החברתי מקיף תחומי דעת שונים, ובכללם סוציולוגיה, אנתרופולוגיה, משפטים, מדעי המדינה, כלכלה פוליטית, גאוגרפיה ותכנון עירוני.40,39

\section{הון תרבותי}

הדיון בהון התרבותי הוא אולי החדש ביותר מבין שאר מחלקות ההון. עבודות קודמות בנושא הamont \&) הגישו את העמימות האופפת את המונח ואת הפערים התאורטיים בחקירתו (Holt, 1998) והרבו לפרשו לאור ההגות המוקדמת של בורדייה בנושא (Lareau, 1988 עבודות אלה ניסו לבחון את הקשר בין ההון התרבותי לבין גישתו של בורדייה להון אנושי, בשהדגש הוא על רכישת השכלה וכישורים (De Graaf et al., 2000; Sullivan, 2001). דיון מקיף ואופרטיבי בהון התרבותי, מכיוון אחר, נערך אצל ת'רוסבי, אשר ניגש לנושא מתוך השדה הסמנטי הכלכלי ומתוך המרחב של גישת ההון (Throsby, 1999). "כלכלנים", כך הוא ציין, "הבחינו כדרך מסורת בין שלושה סוגים של הון: הון כלכלי פיזי, הון אנושי והון טבעי".41 נוסף על סוגים אלה הוא הציע עוד מחלקת הון: הון תרבותי. ההצעה של ת'רוסבי מתרחקת אפוא מההמשגה המוקדמת של בורדייה, שנערכה בתוך השדה הסוציולוגי, ומקרבת אותו אל המתחם האנליטי המאוחד של גישת ההון. מהלך זה מאפשר לת'רוסבי להחיל על נכסי הון תרבותי עקרונות כלכליים כמו "צמיחה", "השקעה" ומבחני קיימות שונים (Throsby, .$(2005,1995$ המונח "תרבות" רווח באסכולות רבות, שם הוא משמש מסמן של תופעות שונות ושל אובייקטים

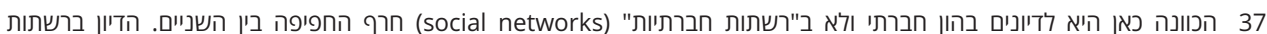

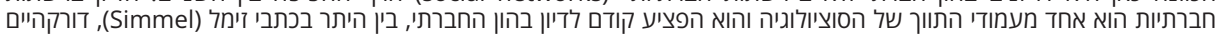

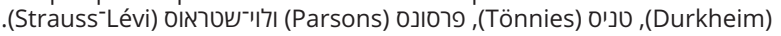

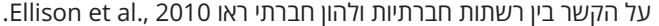

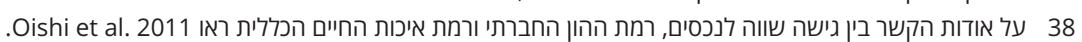

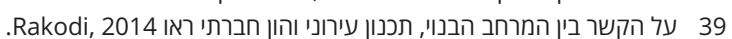
40 בשני העשורים האחרונים הציעו מוסדות וחוקרים שיטות שונות למדידה של מלאי ההון החברתי, על ממדיו ונכסיו. ניתן לעיין במסגרות האלה:

World Values Survey, The Barometer of Social Capital, Putnam's Social Capital Index Instrument, Global Social Capital Survey, World Bank's Social Capital Assessment Tool, World Bank Integrated Questionnaire for the Measurement of Social Capital, Aspects of Social Capital, The UK Social Capital Measurement Framework 41 חשוב לשים לב כי ת'רוסבי אינו דן בהון חברתי, ולכן המשגתו ודיוניו בהון תרבותי עשויים להוביל לחפיפה בין שדה ההון החברתי לשדה 
שונים, לעיתים רחוקות אגב תיחום סמנטי מספק. פרשנות מרחיבה של "תופעות תרבותיות" תקיף למשל פואמה שעשויה להביע משהו בדבר המצב האנושי שקוראיה יוכלו לזהות אותו ולהזדהות איתו; אתר מורשת אשר מציין אירוע היסטורי מכונן כלשהו שבכוחו לכרוך יחדיו חברי קהילה מסוימת; מכלול הסמלים ואוצר המילים המרכיבים שפה משותפת שבאמצעותה ניתן לייצג ולהעביר מסרים. מקרים אלו מדגימים את הערך שנכסי הון תרבותי, גשמיים ולא חומריים, מספקים לקבוצות חברתיות (Throsby, 1999). מכאן נובע שהון תרבותי עשוי נכסים שתורמים ערך תרבותי לחברה. ובניסוח מדויק יותר, הון תרבותי יהיה מלאי נכסי התרבות של החברה. יישום המחשבה הכלכלית מסייע לנו לדמיין "זרם" של שירותי תרבות הנובע מנכסים אלו, שאותו ניתן לערבב עם נכסים אחרים בתהליכי ייצור שניוניים, שלישוניים או למעלה מכך, ולחלופין ניתן להסב מהם הנאה ישירות.

בדומה למחלקות הון אחרות, גם מחלקת ההון התרבותי מורכבת מכמה נכסים שונים שכל אחד מהם מגלם ערך תרבותי כלשהו. הניסוח של פריטים כנכסים נובע מההבחנה שתופעות תרבותיות רבות, למשל אתרי מורשת ומסורת ויצירות אומנות, מחזיקות באיכויות ובתכונות של נכסי הון. התרומה הייחודית שנכסים אלה מספקים לאיכות החיים והאופן שבו הם מעורבים בעסקאות חליפין מחייבים לחשוב עליהם נמחלקת הון נפרדת. קטלוג נכסי תרבות מוחשיים יכלול בין היתר אתרי מורשת ומבנים המגלמים ערך מסורתי וכן יצירות אומנות וחפצים היסטוריים, פסלים וציורים או אובייקטים עתיקים בדמות "מוצרים פרטיים" באוספי אומנות

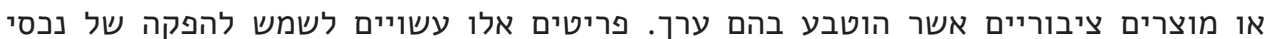
תרבות בעתיד. בהקשר זה אחד מתפקידי המדינה יהיה להסב נכסי הון כלכלי פיזיים לנכסי תרבות באמצעות שינוי ייעוד המבנה ובפעולות הצלה ושימור של המבנה או האתר (ראו גם: המועצה לשימור מבנים ואתרי התיישבות, 2005).42 נכסי תרבות לא מוחשיים, אליבא דת'רוסבי, יכללו את סך הרעיונות, הערכים, האמונות והפרקטיקות שכורכים יחדיו קבוצת אינדיווידואלים ותורמים לגיבוש הזהות האישית והקולקטיבית. את אלו ניתן למצוא ביצירות ספרותיות ומוזיקליות, לדוגמה. עם זאת הדיון בהון התרבותי מסתכן בחפיפה אפשרית עם ההון החברתי, ובשל חפיפה אפשרית זו יש לנסות להימנע ממצב שבו מכניסים תחת כיפתו של ההון החברתי מרכיבים (רעיונות, ערכים, אמונות ופרקטיקות) המזוהים גם כשייכים למחלקת ההון התרבותי. הדיון בנכסי הון תרבותי רווי בשיקולים נורמטיביים, ועל כן מושפע מדעות קדומות, ומוטה. עד כמה שניתן להקים העתק מדויק של נכס התרבות נדמה שדיון ערכי אינו בבחינת מכשול בפני מדיניות ניהול ושימור של נכסים קריטיים. למעשה, היכולת לשכפל נכסי הון תרבות

42 ראו גם המועצה לשימור מבנים ואתרי התיישבות (2005). שימור מבנים ואתרי התיישבות: היבטים ערכיים ומשפטיים, המועצה לשימור מבנים ואתרי התיישבות, ירושלים. 
מפחיתה את מידת ה"קריטיות" שבה הם ניחנים לכאורה. הטיפול בסוגיית המקור - שכפול (modes of being - מצריך בירור אונטולוגי כמו שהוא מצריך (בתור תבניות של קיום) בדיקת היתכנות טכנולוגית.44,43 מנגד, במקרים שבהם שיעתוק אינו אפשרי, ושימור הוא הכרחי, שומה עלינו לסדר את הנכסים לפי עדיפות, שכן הגנה על נכס אחד עלולה לבוא, במוקדם או במאוחר, על חשבון תחזוקת נכס אחר. בלשון כלכלי, עלינו להחיל את מבחן השקל השולי - אם השקל הבא יוקצה לטובת שימור אתר מורשת אחד או אתר מורשת אחר; יצירת אומנות אחת או אחרת. ליתר הרחבה, השיקולים הנורמטיביים בנוגע להון התרבותי עולים בכל קביעת סדר עדיפויות להשקעה בנכסי ההון התרבותי: אם יש לערוך הבחנה בהשקעה בין תרבות גבוהה ("מעודנת") לתרבות נמוכה ("עממית"), ואם יש לשמור על מגוון תרבותי רחב כנל האפשר.

\section{l \\ מוזרויות בטבע ובהתנהגות של נכסי הון}

דיוני המשך בדרכי הזיהוי של נכסי ההון החשובים לאיכות החיים ייערכו בהמשך. לעת עתה יש מקום להתעכב על מוזרויות המאפיינות את נכסי ההון השונים וכן על התגובות הייחודיות שנכסי הון עשויים להפגין בתגובה להפקה, לשימוש או לניצול. פרק זה אינו מתיימר להציג הבחנה מלאה וממצה של טבעם הייחודי של נכסי ההון אלא להציף כמה נקודות בולטות

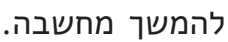

\section{פערים מהותיים בטבע של נכסי הון}

מכל חמש מחלקות ההון, להון הטבעי יש מעמד מיוחד. נכסי הון טבעי אינם זקוקים לנכסים ממחלקות הון אחרות על מנת להתקיים. אדרבה, קיומן של מחלקות הון אחרות "מפריע" לתפקודים של המערכות האקולוגיות, אך כל מחלקות ההון האחרות תלויות תלות קיומית מכריעה במלאי ההון הטבעי. זאת ועוד, חוק שימור החומר מחייב שכל נכסי ההון הכלכלי הפיזיים־מיוצרים הם למעשה סידור מחדש במבנה של משאבים גולמיים - נכסי הון טבעי. כלומר, חומרים קיימים במבנים טבעיים ובמבנים מלאכותיים, ומכאן חשיבותן של טכנולוגיות 
המחזור למול מחסור בנכסי הון חיוניים. גם נכסי הון תרבות הם על פי רוב נכסים מיוצרים, מלאכותיים, שקורות ההיסטוריה, הפולקלור והמסורת הטביעו בהם ערך תרבותי.

נוסף על מעמדו הראשוני של ההון הטבעי, כל מעשה של החלפה בין נכס הון אחד לאחר כרוך בערבוב של הון אנושי, בצורת מיומנויות, של הון חברתי, בצורת מוסדות למחקר ופיתוח ובטכנולוגיה כפי שהיא מבוטאת במלאי פטנטים, לדוגמה. כלומר, תוחלת איכות החיים במציאות של גידול אוכלוסין, של גידול בצריכה ובבסיס משאבים קריטיים מתכלים תלויה בכושר החדשנות החברתי.

\section{פערים מהותיים בתגובה של נכסי ההון לשימוש}

השימוש בנכסי הון מעורר תגובות שונות של הנכסים. אם אנו מניחים קשר בין שני משתנים,

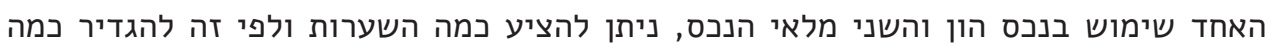
יחסים מתמטיים לתיאור הקשר שבין שימוש בנכס הון למצבו. אפיון כזה הוא הכרחי לצורך

ניהולם.

• יחס שלילי: השימוש בנכס הון מוביל לירידה במלאי שלו. במילים אחרות, ככל שאנו משתמשים יותר בנכס, כך כמותו פוחתת. נדמה שזה המקרה במשאבי טבע מתכלים. מקרה פרטי של היחס השלילי מתרחש כאשר שימוש אינו רק מפחית את המלאי אלא גם גורע מאיכותו. דהיינו, איכות המלאי אינה אחידה ופוחתת למשך זמן הניצול. • יחס חיובי: השימוש בנכס הון גורם לעלייה במלאי. אפשר שזה המקרה בתופעה של אמון הדדי: ככל שסבבי האינטראקצייה בין שני אנשים גדלים, כך עולה רמת האמון ההדדי

.(Buskens, 1998)

• היעדר השפעה: שימוש בנכס אינו משפיע כלל על המלאי. המקרה של רתימת תופעות טבעיות, למשל זרם של אנרגייה סולרית או אנרגייה קינטית לטובת הפקת חשמל, מצביע

על היתכנות של השערה זו במקרים פרטניים (Boyle, 2004). • יחס פרבולי שלילי (עקומת U הפוכה): השימוש בנכס הון מגדיל את המלאי עד נקודה מסוימת (נקודת מקסימום), וכל שימוש נוסף שוחק את המלאי. ייתכן שזה המקרה בשימוש בהון אנושי בתהליכי למידה (וייצור ידע, הגורם שחיקה) (Salehi et al., 2010). תיתכן גם אפשרות לשימוש בר־קיימה במלאים שהצמיחה האינטרינזית שלהם מאופיינת ביחס פרבולי שלילי (optimum sustainable yield), כמו למשל באוכלוסיות דגים (גדלות עד גודל מסוים ואז קטנות) (Pauly et al., 2002) או ביערות (Dauber et al., 2005). נכונותן של השערות אלה דורשת בחינה פרטנית נוספת. עם זאת אפשרותן מדגישה את גבולות המטאפורה של פונקציית הייצור בהקשרי איכות חיים בת־קיימה. 
לבסוף, כל ההשערות לעיל מתייחסות לצריכה עקיפה של נכסי הון באמצעות תהליכי הייצור, כלומר בתוך גבולות השוק. עם זאת צריכה ישירה ובלתי אמצעית של נכסי ההון מחייבת נות עותי בחינה נוספת של אופי התגובה של מלאי ההון. ייתכן שבמקרים מסוימים תגובה זו אינה מתרחשת, או שהיא אינה מחוללת תמורות במצב המלאי, למשל במקרה של הנאה מתועלות לא גשמיות שמספקות המערכות האקולוגיות: השראה או בילוי.

\section{T \\ קשרים בין סוגי הון, קשרים בין נכסי הון וקשרים בין אלה לאלה}

נכסי ההון של מדינה, שכאמור אינם דבר סטטי, והם מצויים בשיווי משקל דינמי עם הסביבה החיצונית, עוברים שינויים איטיים בתגובה לאינטראקציות שונות. הם יציבים וגמישים בעת ובעונה אחת.45 את האינטראקציות של נכסי הון עם הסביבה ניתן לחלק לשני סוגים: ערוצים של השפעה תוך־הונית, שאותה ניתן לכנות גם השפעה פנימית (endogenic), וערוצים של השפעה חוץ־הונית, או השפעה חיצונית (exogenic).

השפעות פנימיות מתייחסות להשפעות בין נכסי הון באותה מחלקת הון. במחלקת הון טבעי ניתן לקחת כדוגמה את השפעתן של תכונות הקרקע על מצב מאגרי המים הטבעיים. השפעה אחת היא הקשר בין נקבוביות הקרקע (porosity) לזרימת המים במסעם במצע הנקבובי (האקוויפר) אל האקוויקלוד - רעיון מרכזי במדעים הידרוגאולוגיים. מובן שתהליכים של היזון חוזר משפיעים על יחסים אלו. ערך הנקבוביות האינטריסטי של הקרקע (n) כפוף לשינויים טמפורליים: האם זו יבשה או רוויה? השפעות חיצוניות מתייחסות לאינטראקציות בין נכסי הון במחלקות הון שונות. כאן ניתן Kampa \& Castanas,) לעסוק, למשל, בקשר שבין איכות האוויר לבין מצב התחלואה 2008) או לתאר השפעות מסדר שני ומסדר שלישי: פגימתו של אוויר מזוהם במצב הבריאות,

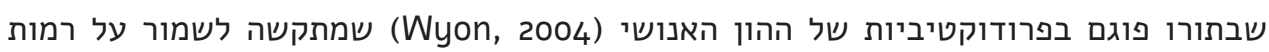
דומות של פיתוח כלכלי. למותר לציין שההשפעה בין נכסי הון עשויה להיות חיובית או שלילית, ליניארית, מעריכית, מקוטעת או לא־ליניארית, חד־סטרית או דו־סטרית, ובעוצמות

45 כפי שהוצג קודם לכן, עקרון ההומאוסטאזיס מסייע לתאר את מלאי ההון כצבר של פריטים המצויים בשיווי משקל דינמי עם הסביבה החיצונית. 
שונות. ניתן גם להצביע על קשרים חזקים במיוחד בין נכסי הון, למשל הקשר שבין הון כלכלי פיזי־מיוצר להון טבעי, אשר בלעדיו אין חומר, או השפעתם של תהליכים פרטניים של ייצור, דוגמת הפקת חשמל, על מצב הסביבה הטבעית. דוגמה נוספת היא הקשר בין הון אנושי, ובייחוד חינוך ומיומנויות, לכל אחד מגורמי הייצור האחרים; לרעיון פונקציית הייצור ולאופן שבו טכנולוגיה מרחיבה את גבול אפשרויות הייצור (עקומת התמורה; production possibility frontier

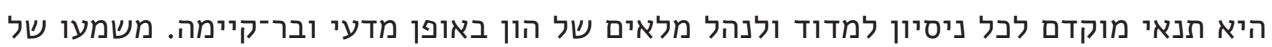
הטבע המשתנה של בסיס המשאבים הלאומי הוא גמישות יחסית בעיצוב של ההשפעות בין סוגי ההון. למשל, הון כלכלי מיוצר חדשני עשוי למנוע פגיעה בבריאות האדם ולצמצם את צריכת המשאבים בתהליכי ייצור באמצעות טכנולוגיות מחזור. במילים אחרות, יחסים שליליים בין מחלקות הון אינם דטרמיניסטיים. דרך אחת לגשת למיפוי האינטראקציות בין מחלקות הון היא להתחיל בסרטוט גבולות למערכת ייחוס כלשהי ובאמצעותה לבחון את נכסי ההון המעורבים בה. מערכת ייחוס עשויה להיות מקרה פרטי של פוקנציית הייצור הכללית: מערכת הבריאות, למשל, כתהליך ייצור של שירותי בריאות (שירותי רפואה) או מוצרי בריאות (אנטיביוטיקות). מייד מתחוורים נכסי ההון המעורבים בהספקתם של מוצרים ושירותים אלו. מתודולוגיית דינמיקת המערכות מציעה כלים לביצוע מודלים מסוג זה (ראו להלן בפרק "מדדי הון ומדיניות"). מלבד ההשפעות שבין נכסי הון לבין עצמם יש עליהם השפעה גם של המבנה המוסדי החברתי והפוליטי. מבנה מוסדי זה, הערכים, הנורמות והחוקים החברתיים מווסתים את האינטראקציות ומאפשרים אותן. מצבו של ההון הטבעי מושפע במיוחד, כך לפי מאטסון ואחרים (Matson) 2016 משאבי טבע משותפים, מנגנונים של שיתוף פעולה, יישוב סכסוכים, הקצאת זכויות קניין

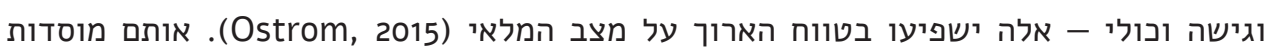
עשויים גם לקבוע אם המשעול שבו צועד המשק הלאומי מוביל לשגשוג, ואם קדמה זו היא בת־קיימה (Acemoglu \& Robinson, 2012). 


\title{
תופעות חיצוניות לשדה האנליטי של גישת
}

\begin{abstract}
ההון תופעו
יישומה של תאוריית גישת ההון ככלי למדידת איכות חיים בת־קיימה מחייב בחינה של תופעות שונות שמקורן מחוץ לתיק הנכסים של מדינה, אך כאלו שמחזיקות בהשפעה מסוימת על הארגון, על ההקצאה ועל החלוקה של נכסי ההון. ניתן למנות תופעות חיצוניות רבות, אך סקירה זו, שיוצאת מהשקפה שממוקדת באדם, מציגה רק שתיים: תופעת הגידול הדמוגרפי ותופעת האידאולוגיה.
\end{abstract}

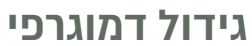

גידול האוכלוסין, שמבטא שינוי חיובי במספר הפרטים של האוכלוסייה האנושית, הוא תופעה

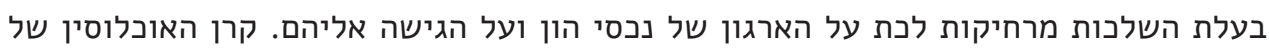
האומות המאוחדות מעריכה כי בעשר השנים הקרובות שיעורה של האוכלוסייה העולמית יהיה בשמונה מיליארד וחצי נפשות (UNFPA, 2018). בתוך כך העלייה בתוחלת החיים בשילוב

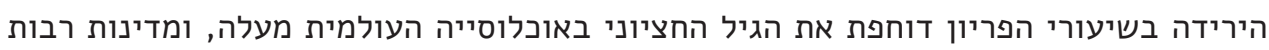
חוות הזדקנות דמוגרפית מואצת (UNFPA, 2018). תופעות אלו, בצל המעבר לערים, כאשר עד שנת 2030 שיעורה של האוכלוסייה העירונית העולמית צפוי להיות כחמישה מיליארד בני אדם (Social Development. Population Division, 2002), ועל רקע תהליכי הגירה מאסיביים (Castles et al., 2013), צפויות להשפיע על מערכות קריטיות התומכות באיכות

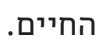

הגידול הדמוגרפי והזדקנות האוכלוסין, ביחד ולחוד, יחייבו השקעות ניכרות בהרחבת שירותי בריאות ורווחה (Schneider \& Guralnik, 1990). המשמעות מבחינת אוסף נכסי ההון הקריטיים היא עקה בשיעור חסר תקדים, ביקוש מאמיר, הגבלת גישה, ובהיעדר תחלופה - הפיכתם של נכסים מוגבלים ומתכלים לקריטיים אף יותר. ממדי האתגר הקנו לתופעה הדמוגרפית את השם "פיצוץ האוכלוסין" (Ehrlich \& Ehrlich, 1990) או "פצצת האוכלוסין" (Ehrlich, 1978). במדינות אחדות גידול האוכלוסין וצפיפות האוכלוסין עלולים לגרום נזקים ניכרים לאיכות החיים. לאחרונה טענה זו נשמעת בנוגע לישראל (Tal, 2002). 


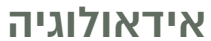

תופעה חיצונית נוספת היא האידאולוגיה. אידאולוגיה, רדיקלית יותר או פחות, כמערכת של רעיונות מופשטים המכוונים לפעולה, ${ }^{46}$ מושלת במוסדות החברתיים - באמצעות הבניית משמעויות וערכים והקניית לגיטימציה לכוח פוליטי - ואלו מושלים בבסיס המשאבים החברתי. אנו מקצים נכסי הון למטרות שונות, מתחרות, לעיתים סותרות, לתמיכה בתהליכי ייצור שונים. קונפיגורציות ההקצאה הן מבחינה מעשית אין־סופיות. זאת ועוד, מאחר שהקצאת מלאי הון אינה מקסום רווחים אלא מקסום תועלות וסיפוק, או מקסום איכות חיים, כל סידור "אופטימלי" של הקצאה הוא עניין ערכי, נורמטיבי ו"אופטימלי לכאורה". אם כן, האידאולוגיה שבה "מחזיקה" או שאותה "מתרגלת" האוכלוסייה, מתווה תפיסת עולם מסוימת בנוגע לפשר החיים הטובים. לפיכך האידאולוגיה מכווינה מוסדות, מארגנת משאבים ומקימה אתוס של צריכת משאבים ראויה לנפש (למשל אתוס צרכני [Veblen, 1994 [1899), והיא מוסיפה לשחק תפקיד בהגדרת החיוניות של נכסים (עד כמה קריטיות של נכסים היא עניין נורמטיבי, ראו להלן בפרק "תחליפיות של נכסי הון"). סוגיה זו סבוכה אף יותר כאשר מוסיפים עליה את שאלת כמות הנכסים שיש להותיר לדורות הבאים, שאלה שהיא ערכית ונטולת מענה מוחלט .(Parfit, 1982) המשמעות של אידאולוגיה עבור תאוריית גישת ההון אינה מסתכמת בארגון בסיס המשאבים החברתי או בהקצאת משאבים אלא באופן שעלול להתברר כהרה אסון, בקביעת מידת הקריטיות של נכסי הון, כאמור לעיל. לא קשה לראות מדוע תכתיבים אלו מוטעים, ושהאידאולוגיה כופה עלינו לא אחת עמדה שגויה, פונדמנטליסטית; היא מתקינה עלינו סַבֵּי עיניים, אשר במרוץ הזמן עלולים להצעיד אותנו אל סף תהום. 


\section{מבחנים לזיהוי נכסי הון קריטיים}

הפרקים הקודמים בסקירה ערכו הבחנה בין הון לנכסי הון והגדירו את חמש מחלקות ההון (הון כלכלי, הון טבעי, הון אנושי, הון חברתי והון תרבותי). עם זאת הם הותירו שאלה מעשית לא פתורה: כיצד ניתן להתמקד בנכסי הון מסוימים ולו לשם המלצה על סדרי עדיפויות בניטור, במדידה ובניהול ציבורי של משאבי ההון? היות שנכסי ההון משיאים לאיכות החיים כל אחד תרומה שונה, יש צורך להבחין בין נכסים חיוניים יותר ופחות.

עד כה מוסדות המחקר והממשל שפיתחו את תאוריית גישת ההון לא הצליחו להמציא קריטריונים או מבחנים לזיהוי נכסי ההון הקריטיים, לדרך הגדרת מידת חשיבותם ולתיעדוף ביניהם. פרק זה מציע הצעה לחמישה מבחנים מסוג זה. זוהי רשימה לא ממצה, והיא מוצעת כאן לראשונה. יש צורך להוסיף ולבחון את מהותו של כל מבחן: אם הוא תנאי מספיק או הכרחי להגדרת נכס כקריטי, ומה ההשפעות ההדדיות השוררות בין המבחנים השונים. יש לבחון גם אם יש להרחיב את הרשימה ולכלול מבחנים נוספים. אף שמטרתם של מבחנים אלה היא לסייע לנו לזהות את נכסי ההון הקריטיים לאיכות החיים בישראל, הם עשויים לשמש למטרה דומה גם למדינות אחרות.

מבחני הקריטיות (שאותם ניתן לכנות גם "מבחני חיוניות" או "מבחני חשיבות") משמשים "מסננות" למיון נכסי ההון השונים. הם יסייעו לקבוע כי איכות החיים בישראל תלויה בנכסי הון מסוימים יותר מאשר באחרים. ככל שעוצמת תלותה של איכות החיים בנכס הון כלשהו רבה יותר, כך היא עשויה לקבוע את הגדרת נכס ההון כ"נכס קריטי", "נכס חיוני" או "נכס חשוב" מנכסים אחרים. לדוגמה, נפי שהוצג קודם לכן, נכסי הון אחדים תורמים לרמת הרווחה החומרית בשעה שאחרים מאפשרים את עצם הקיום האנושי. האחרונים קריטיים לאיכות החיים יותר מהראשונים. ניתן ליישם מדרגיות של קריטיות במחלקות הון אחדות, אולם לפי חלוקה לנכסים תומכי חיים ולנכסים תומכי איכות חיים, מיון זה עלול להתברר כמעשה מורכב יותר במחלקות הון אחרות.

רעיון הקריטיות מופיע בספרות בנוגע ל"הון קריטי", אך הוא מתייחס לממדים ולפריטים ספציפיים ביותר של מלאי ההון, ולכן עולה בקנה אחד עם "פירוק" ההון לסדרת נכסים (Ekins 
et al., 2003; Ekins, 2003; Chiesura \& De Groot, 2003; Benhabib \& Spiegel, 2005;

.(Hediger, 2000

אפשר של"קריטיות" תהיינה הגדרות אחדות. לפי מילון אוקספורד (הגדרה 3.2), קריטיות היא תכונה המעידה על "חשיבות מכרעת". תופעה או גורם כלשהם יהיו (being critical) קריטיים אם הם ישפיעו השפעה מוחלטת ומכרעת על קיומו, על טבעו או על תוצאתו של תהליך שבו הם מעורבים. דרך אחת לדמיין את נחיצותם של נכסים קריטיים לאיכות החיים היא לנסות לדמיין אם היינו יכולים לחיות את החיים בלעדיהם. אוויר נקי לנשימה, לדוגמה, הוא גורם קריטי לקיום אנושי בריא ומתמשך, והוא חשוב לאין שיעור מגורמים אחרים.47 על בסיס ההגדרה המילונית ניתן לנסח שלושה מבחנים או תנאים ראשוניים.

\section{מבחן הזמינות או מבחן המוגבלות}

זמינותו של נכס ההון צריכה להיות מוגבלת על מנת שהוא ייחשב קריטי. ליביג (Liebig) נתן לתופעה זו את השם "חוק המינימום" (law of the minimum). לפי החוק, התפתחות נקבעת ניבת בכל רגע נתון לא לפי סך המשאבים הזמינים לתהליך הפיתוח אלא לפי המשאב הנדיר ביותר (scarce), בהתחשב בצורך.48 לשיטה זו, למשל, קצב ההתפתחות של צמח או של אוכלוסייה ביולוגית מוגדר לפי זמינות "הגורם המגביל ביותר": גורם ביוטי (מקור תזונה) או אביוטי (אור) (Smith et al., 1998). כך, הגורם המגביל ביותר הוא הקריטי ביותר להתפתחות

$$
\text { 49. (באותה נקודת זמן) }
$$

לצורך המחשה נניח שאיכות החיים תלויה בשימוש בנכס הון מסוים, למשל מלאי החול הדק בתפקידו כחומר גלם בתהליכי בנייה.50 אם מלאי הון זה מוגבל (אם הזמינות שלו (sand) מוגבלת), אז במוקדם או במאוחר איכות החיים שלנו תינזק, או לכל הפחות יינזק אותו ממד של איכות חיים שתלותו במשאב גדולה מאוד. כך, בנקודת זמן עתידית מלאי ההון הנדון (חול

\footnotetext{
47 הגדרה נוספת של המונח עשויה להאיר גם היא את הרעיון הזה: היא מתארת קריטיות במונחים פיזיקליים (הגדרה 4). במובן זה, קריטיות

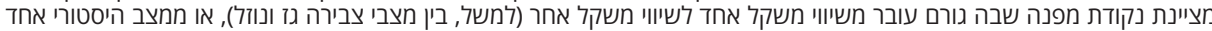

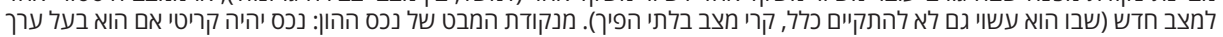

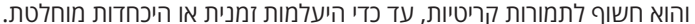

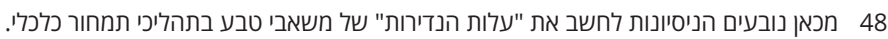

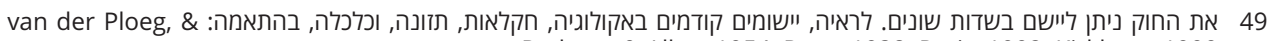
.Redman \& Allen, 1954; Rose, 1938; Paris, 1992; Kirkham, 1999

50 זה אינו רק תרגיל מחשבתי. ראו סקירת קרן המטבע העולמית (IMF) משנת 2015 ודוח האו"ם משנת 2014 בנושא: .International Monetary Fund (IMF), 2015; United Nations Environment, 2014
} 
דק) יחזיק בתפקיד כפול כלפי איכות החיים - הוא ישמש גם "גורם ייצור" של איכות חיים וגם "גורם מגביל" של איכות חיים. דהיינו, הוא יגביל את אפשרויות השיפור ברווחה, יסייג את כושר הצמיחה הכלכלית ויתחום את הרחבת החירויות והזדמנויות הצריכה, שהרי איכות החיים המודרנית היא בעיקרה חוויה עירונית, של הסביבה הבנויה. בדוגמה זו, אם זמינותו של חול דק היא הנדירה ביותר בתהליך הבנייה, יחסית לכל התשומות האחרות, נגדיר אותו "גורם מגביל", ולכן קריטי לתוחלת הבנייה.

מכאן גם נובע שקריטיות של נכסי הון היא יחסית לגורמים אחרים בהקשר של התופעה הנדונה ושיש לה היבט זמני. אולם גם אם המשאב אינו מוגבל בהווה, הוא עלול להיות מוגבל בעתיד. לשון אחר, גם אם המשאב אינו נדיר היום, הוא עשוי להיות נדיר מחר ואז להגביל תהליכי פיתוח. לכן עלינו לשאול אם המשאב מתחדש או מתכלה, ומכאן גם מה קצב ההתכלות ומתי הוא צפוי להתכלות.

\section{מבחן שני - - - - - 2}

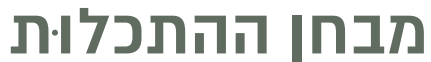

אחת ההבחנות הראשונות והשימושיות ביותר בניהול מלאי משאבים היא הקביעה אם מלאי ההון מתחדש או מתכלה. למשאבים מתחדשים יש היכולת לגדול לאורך זמן. משאבים טבעיים ואנושיים יכולים לגדול בתהליכים של רפרודוקציה ביולוגית; משאבים חברתיים יכולים לגדול

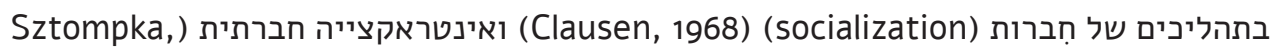
1999 (1994,), משאבים תרבותיים יכולים לגדול בתהליכים של יצירה תרבותית; משאבים כלכליים יכולים לגדול בתהליכים של ייצור כלכלי.

כושר ההתחדשות של משאב נוגע ליכולת האינהרנטית שלו להתחדש, לכמות ההתחלתית שלו ולקצב ההתחדשות. שלושה גורמים אלו מושפעים בתורם מטבע המשאב ומהנסיבות הסביבתיות, החברתיות והטכנולוגיות שעשויות להאיץ או למתן את קצב ההתחדשות. אפילו למשאב יש יכולת התחדשות, אם קצב ההפקה שלו יעלה על קצב ההתחדשות שלו (תופעה המכונה ניצול יתר), הוא עתיד להתחסל.51

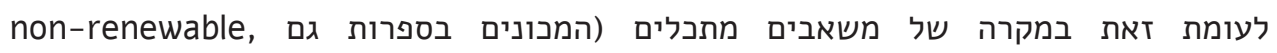


אין קצב חיובי של הפקה או ניצול (exhaustible, depletable זמן מבלי שהמשאב ידולל, ירוקן ויתכלה. הווה אומר, כל שימוש עכשווי במשאב גורע מהמלאי העתידי שלו.52 אם המשאב, או נכס ההון, מתכלה או שהוא בסכנת התכלות (הווה אומר קצב המיצוי עולה על קצב ההתחדשות), ובתנאי שהוא בעל חשיבות מכרעת לאיכות החיים, נגדיר אותו "נכס הון קריטי".

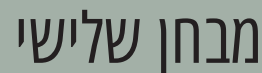

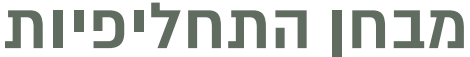

קריטיות של נכס הון עשויה לנבוע מטעם נוסף על זמינותו של הגורם בתהליכי פיתוח טבעיים, חברתיים או כלכליים (היותו "גורם מגביל") ועל כושר ההתחדשות שלו (היותו "משאב מתכלה"). המבחן השלישי עוסק בגמישות התחלופה של הנכס. גמישות התחלופה של נכס הון מבטאת את היכולת שלנו להחליף משאב אחד באחר בתהליך הייצור או הצריכה ולשמור על אותה רמת תועלת לאיכות החיים.53 נהוג לומר שכאשר שני משאבים זהים זה לזה מבחינת התועלת שהם מסיבּים או מבחינת השימושיות שלהם בתהליכי ייצור, גמישות התחלופה שלהם זה בזה היא אין־סופית. ניתן להחליף כל כמות של המשאב הראשון במשאב השני. כאשר המשאב נדיר וכאשר אין לו תחליף בנמצא, נהוג לומר שגמישות התחלופה שלו עם משאב(ים) אחר(ים) היא אפסית. יש במובן טווח ביניים, קרי גמישות תחלופה שנעה בין o ל־100 אחוז (או בין o ל־1). הפרק הבא "תחליפיות של נכסי הון" עוסק באפשרות זו.

ראוי להדגיש כי ניתן להחליף נכסים בתוך אותה מחלקת הון, מה שנכנה בסקירה זו "תחלופה תוך־הונית", או "תחליפיות פנימית". למשל, החלפה של מקור מים אחד במקור מים אחר לאותם שימושים או החלפה של מתכת אחת במתכת אחרת לייצור מוצר בעל תפקודים זהים. כמו כן ניתן להחליף נכסים בין מחלקות הון, מה שנכנה בסקירה זו "תחלופה בין־הונית" או "תחליפיות חיצונית". למשל, החלפה של מאגר מים במפעל התפלה (כלומר נכס הון טבעי

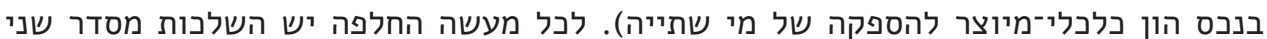

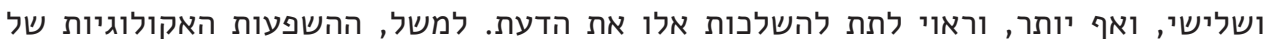

52 אנו אומרים שקצב הגידול של המשאב אפסי, אך בפועל הוא שואף לאפס במונחי הזמן שלנו (זמן אנושי) ומתחדש לאיטוט, על לוח הזמנים

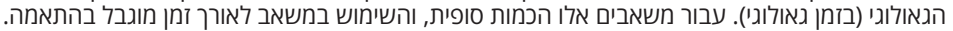
53 הסקירה אינה מיישמת את רעיון גמישות הביקוש בשל קשיי התמחור שמאפיינים נכסי הון רבים כל כך. 
הזרמת מי רכז עתירי מלחים לסביבה - תוצר לוואי של התפלת מים.

אם גמישות התחלופה של נכס היא אפסית או שואפת לאפס, נגדיר אותו "נכס קריטי" גם אם

הוא אינו גורם מגביל בעת הנוכחית.54

\section{שני מבחנים נוספים: קריטיות בהקשר נתון}

קריטיות של נכסי הון אינה תלויה אך ורק בטבעו של הנכס עצמו - אם הוא מוגבל, מתכלה ותחליפי - אלא גם בהקשר החיצוני. לכן סקירה מדעית זו קובעת כי לא ניתן לקבוע, או לדחות, את עובדת היותו של נכס קריטי על פי שלושת המבחנים האלה בלבד, אלא יש להסתמך על ניתוח ההקשר ההיסטורי־תרבותי־לאומי שבו הנכסים התקיימו ושבו הם מוסיפים להתקיים. לצורך כך הסקירה מציעה שני מבחנים נוספים.

הצורך לדון בהקשר שבו מתקיימים ומנוצלים נכסי ההון מבטא פרגמטיזם או ספקנות מסוימת. ייתכן שאין באפשרותנו לקבוע א־פריורית ואוניברסלית שנכס מסוים הוא קריטי לאיכות החיים. בדרך זו האופי הזמני ותלוי ההקשר של הנכסים הקריטיים מעיד גם על האופי הזמני ותלוי ההקשר של איכות החיים.

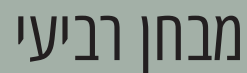

\section{מבחן הזיקה הלאומית}

מבחן הזיקה קובע כי עלינו להתמקד בנכס הון בעל זיקה ישירה וחזקה לאיכות החיים במדינת הלאום הנדונה ולא בנכסי הון שאינם כאלה. הזיקה של נכס ההון למדינת הלאום עשויה להיות מסוג גאוגרפי או מסוג קנייני. כלומר, הזיקה של נכס הון לאיכות החיים עשויה לנבוע משני

מקורות.

הזיקה הגאוגרפית של נכס הון נוגעת להימצאותו בשטחה של המדינה, אולם יש גם נכסי הון הממוקמים, איפסו פקטו, מחוץ לגבולות מדינת הלאום. לדוגמה, במקרה של ההון הטבעי, ברי כי כל מדינה התברכה בנכסי הון טבעי שונים לפי הפיזור האקראי של עתודות משאבי

54 השימוש במונח "הון טבעי קריטי", למשל, נועד להדגיש את התחליפיות המוגבלת של ממדים ורכיבים מסוימים של הון טבעי - אותם

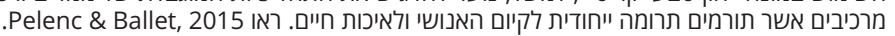


טבע בעולם (לא כל מדינה מחזיקה בעתודות מינרלים נדירים, לדוגמה). על כן רשימת נכסי ההון תלויה בהקשר הלאומי־גאוגרפי.

עם זאת יש מקום להרהר במעמדם של נכסי הון מסוימים, למשל נכסים מסוג מוצרים משותפים, שאינם נמצאים בשטח הגאוגרפי של מדינה כלשהי (מבחינת אזור הריבונות הכלכלית שלה), אך עדיין יכולים להיות בעלי השפעה על מצב איכות החיים באותה המדינה, למשל, באמצעות מגמות ותהליכים גלובליים או בתיווך של מערכות עולמיות כמו מערכת האקלים.

הזיקה הקניינית של נכס הון לאיכות החיים הכללית עשויה להיות שיקול נוסף על זו הגאוגרפית. השתיים נבדלות זו מזו, ולעיתים אין חפיפה ביניהן. יש נכסים רבים בבעלות ישראלית (בבעלותם של ישראלים) שנמצאים מחוץ לישראל. כמו כן יש נכסים הנמצאים בישראל אך הם בבעלות זרה, ועל כן הם מחוץ לספרי החשבונות.55

אולם יש לשים לב שקביעת הזיקה הקניינית אינה תמיד פשוטה. המקרה של נכסי הון כלכלי פרטיים (המכונים גם מוצרים פרטיים) הוא הקל ביותר. אך יש מקרים מורכבים יותר, למשל אלה של מוצרים ציבוריים או מוצרים משותפים, מתחום ההון הטבעי, האנושי או התרבותי. בתחום ההון הטבעי מערכת האקלים היא אולי הדוגמה הבולטת ביותר: האם על הריבון להתערב בה - ומה יכולתו - כדי שמצבה יישמר לאורך זמן? גם במקרה של נכסי הון אנושי או תרבותי נדרש עיון נוסף, לדוגמה: כיצד עלינו לגשת לשאלת הזיקה של המיומנויות והכישורים של ישראלים המתגוררים בתפוצות לאיכות החיים הכללית בישראל? כיצד ניתן לקבוע את הזיקה בין הון תרבותי למדינה מסוימת בעולם גלובלי? מה המשמעויות של אלו על הקצאתם על ידי המדינה, או לחלופין, על השקעה בהם?

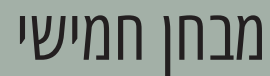

\section{מבחן הריבונות}

לעומת מבחן הזיקה, העוסק בקשר שבין נכס ההון למדינת הלאום, מבחן הריבונות עוסק ביכולתה של המדינה לנהל את הנכס כמי שאחראית לאיכות החיים של אזרחיה בהווה ובעתיד וכזו המשופעת בסמכויות ובאמצעים לארגן את בסיס המשאבים במדינה. בעקבות זאת מבחן הריבונות הוא בעל גוון אופרטיבי. הוא קובע כי אין דחיפות לדון בנכסי הון ששוכנים מחוץ

55 במובן זה, הנכסים אינם ״של המדינה״ אף שזרם מסוים של תועלות שהם מספקים עשוי לזרום, לפחות בחלקו, לקופת המדינה בדמות 
להשפעה הריבונית הישירה של המדינה, הווה אומר נכסי הון שנמצאים מחוץ להישג ידה הרגולטורי של הממשלה.56

יש מערכות המעורבות בהשקעה, בהפקדה או בהחלפה של מלאי הון הנמצאות בכפיפות כמעט גמורה לריבונות המדינה, כמו מערכת החינוך והבריאות. לעומת זאת נכסי הון אחרים עשויים להיות רחוקים מהישג ידה של המדינה על אף חשיבותם לאיכות החיים.

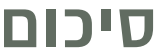

חמשת המבחנים שהוצען לעיל - מבחן המוגבלות, מבחן ההתכלות, מבחן התחליפיות, מבחן הזיקה הלאומית ומבחן הריבונות - מקנים כלים אנליטיים להעדיף באמצעותם את הדיון בנכסי הון אחדים על פני אחרים. אלו יהיו נכסים שאנו עשויים להגדיך "ישראליים", נכסים שמדינת ישראל מוסמכת, ויש ביכולתה, לנהל אותם ונכסים חיוניים במיוחד לאיכות החיים: משאבים נדירים, מתכלים, שעשויים להגביל את הבחירות שלנו ואת תהליכי הפיתוח האנושי, ומשאבים חסרי תחליף. חשוב להדגיש כי התלות בנכסי ההון השונים היא ארעית ועשויה להשתנות בחלוף הזמן. כפי שניכר לאורך ההיסטוריה, פריצות דרך מדעיות וחדשנות טכנולוגית ותעשייתית עשויות לייתר את התלות בחלק מנכסי ההון או להשיל את חיוניותם, למשל באמצעות הגדלת אפשרויות או גמישות התחלופה שלהם (ראו להלן פרק "טכנולוגיה, קריטיות ותחליפיות של נכסי הוך"). לכן על העיסוק בגורמי הייצור הקריטיים של איכות החיים בישראל לעבור בחינה מחודשת מעת לעת. אפשר שחלק מהם יאבדו ממידת הקריטיות שאפיינה אותם בעבר.

56 זאת בהנחה שהמטרה היא לסייע לשמור על רמת איכות החיים של התושבים המתגוררים בישראל באמצעות ניהול מלאי ההון

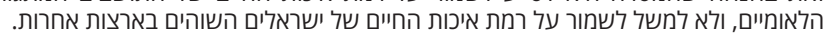




\section{סוגיות מרכזיות ביישום גישת - - n קון}

יישומה של תאוריית גישת ההון למדידת איכות חיים בת־קיימה אינו מתמצה רק בזיהוי נכסי ההון הקריטיים לאיכות החיים. מטרתו של חלק זה בסקירה היא להאיר סוגיות מפתח העולות מתאוריה זו כנקודת מוצא לשימוש יישומי מושכל יותר. חלק זה ידון לעומק בשאלת אפשרות התחלופה של נכסי ההון אלה באלה ובהשפעות האפשריות של הטכנולוגיה על מידת הקריטיות והתחליפיות של נכסים. עוד הוא ידון בחשיבותה של בחינת הגישה לנכסי הון, באי־הוודאות שעולה בעת השימוש והמדידה של נכסי ההון, בחיבור האפשרי של גישת ההון לדינמיקת מערכות ולהערכת חוסן, ולבסוף בתרומתה של גישת ההון למדיניות הציבורית.

\section{N \\ תחליפיות של נכסי הון ושתי גישות לקיימות}

אחת השאלות המהותיות ביותר במדע הכלכלה היא אם ניתן להחליף מלאי מסוים של הון במלאי אחר בעל תכונות אינהרנטיות שונות ובפיזור גאוגרפי אחר מבלי להתפשר על רמת איכות החיים. לשאלה חשיבות רבה גם בעת הערכתה של מידת הקיימות של איכות החיים ובחינת מידת הקריטיות של נכסי ההון השונים. המניע להחלפה של הון אחד באחר הוא ברור: היא מרחיבה את גמישות התחלופה של נכסי

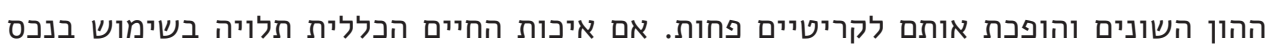
הון מסוים; אם נכס הון זה סופי ומתכלה; אם אין לו תחליף בנמצא, אז במוקדם או במאוחר פוטנציאל הצמיחה הכלכלית, העלאת רמת הרווחה והרחבת הזדמנויות הצריכה יוגבלו. הזמינות המוגבלת שלו, הסופיות שלו וגמישות התחלופה שלו מקנות למלאי הנדון איכויות 
שאותן כינינו "קריטיות". סוגיה זו שוכנת בטבורה של בעיית איכות החיים המתמשכת, שכן אם חירויות והזדמנויות צריכה, במובנה הרחב ביותר של צריכה, תלויות בהפקת תועלות ישירות ועקיפות ממלאי הון, ומלאי הון אלו עלולים להתחסל מבלי שיימצא להם תחליף שקול, אזי אין רמה של איכות חיים שניתן לשמור עליה לאורך זמן. במילים אחרות, אם נכס ההון מגביל אותנו (קרי אם הוא קריטי), אנו רוצים להמציא לו תחליף או לשכך את תלותנו בו.

\title{
תחליפיות בראי פונקציית הייצור
}

כדי לבחון את רעיון התחלופה של נכסים הספרות נוטה לצמצם את היקפי הבעיה ולאמץ מחדש את ההנחות הפשטניות על טבעם של תהליכי ייצור כפי שאלו מיוצגים בגרסה מוקדמת של פונקציית הייצור (ראו הרחבה קונספטואלית ראשונה לעיל בפרק המבוא).$$
\mathrm{Q}_{\mathrm{i}}=f\left(\mathrm{~L}_{\mathrm{i}}, \mathrm{K}_{\mathrm{Ei}}, \mathrm{K}_{\mathrm{Ni}}\right)
$$ \\ פונקציית ייצור של משק לאומי i.
}

או בנוסח כללי

$$
\mathrm{Q}=f\left(\mathrm{~L}, \mathrm{~K}_{\mathrm{E}}, \mathrm{K}_{\mathrm{N}}\right)
$$

כאשר Q מבטא תפוקה, L מבטא עבודה, KE מבטא הון כלכלי, KN מבטא הון טבעי.

כעת נדמיין משק לאומי שנשען כולו על תפוקה אחת (Q), ולכן על פונקציית ייצור אחת הכוללת עבודה (L) ותערובת כלשהי של הון טבעי (חומרי גלם) והון כלכלי (מכונות) כתשומות. נשער גם שההון הטבעי הומוגני ועשוי רק נכס הון אחד, למשל פחם (coal), שקצב ההתחדשות שלו נמדד בשעון גאולוגי, ועל כן ניתן להגדירו משאב מוגבל ולא מתחדש. עכשיו נשער צריכה בלתי אמצעית של פחם, היישר מן הטבע, ללא שימוש במכונות בתהליך הייצור (כלומר KE=0). כמות התפוקה שאנו מקבלים תלויה, במילים אחרות, בכמות משאב הטבע. במודל זה אין רמה חיובית של שימוש בהון טבעי שעשויה להימשך לנצח. לאחר שמלאי ההון יתכלה, תהליך הצריכה ייפסק, התפוקה תצנח לאפס, ואיתה - רמת הרווחה במשק הלאומי.

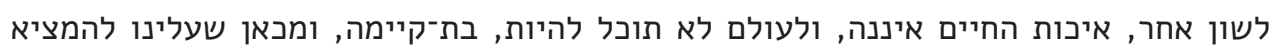

$$
\text { למשאב הטבע תחליף.57 }
$$

ננסה אפוא להציג מחדש בפונקנצייה מלאי של הון כלכלי, גם הוא הומוגני, עשוי רק סוג

57 נזכיר כאן את כלל הארטוויק־סולו לרווחה מתמשכת, הנדון לעיל ומניח תחליפיות בין מחלקות הון. יתרה מזאת, לפי חוק הארטוויק, הרנטה שמתקבלת בתהליך הניל הניצול של הון טבעי מושקעת בהון כלכלי שלי שמשכך את התלות בהון הטבעי. מצב דברים זה מותנה כמובן

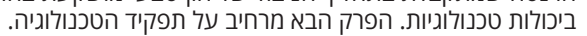


אחד של נכס מסוג מכונות (כלומר KE>0). השאלה שעולה היא אם שימוש בפחם בשילוב מכונות (תחת צריכה ישירה של פחם מן הטבע) מאפשר למשק לשמור על רמת תוצר חיובית, כלשהי, לזמן בלתי מוגבל. התשובה לשאלה נוגעת לגמישות התחלופה של משאב הטבע עם מכונות במסגרת תהליך הייצור, שהוא תהליך הפיתוח של תפוקה Q. למן שנות השבעים של המאה העשרים הציעו חוקרים הנחות שונות לשאלת גמישות התחלופה בין משאבי טבע והון כלכלי (משמע מודל פשוט) בניסיון להגדיר את התנאים שבהם ניתן לשמור על ייצור

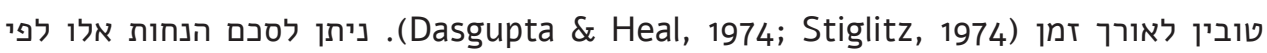
שלושה מקרים: הנחת תחליפיות מושלמת ומלאה (כאמור, עבור שני סוגים של הון: טבעי וכלכלי), הנחת תחליפיות חלקית והנחת אי־תחליפיות. במקום אחר (Perman et al., 2011) הספרות הציגה את שלוש ההנחות באמצעות שלוש עקומות ייצור (Q1, Q2, Q3), המכונות איזוקוואנטים (isoquant). (1ו1).
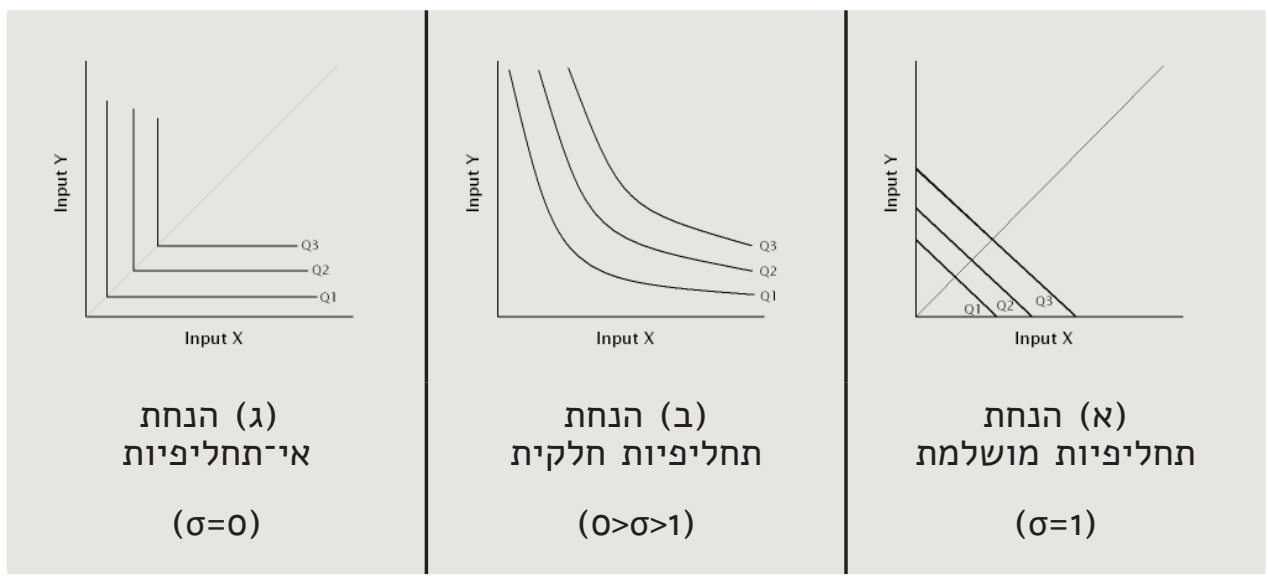

מקור: Isoquants, Wikimedia Commons.

כאשר Q מבטא תוצר, Q3>Q2>Q1, תשומה X מבטאת הון טבעי, תשומה Y מבטאת הון כלכלי (גמישות התחלופה מסומנת באות $\sigma)$.

בהנחת תחליפיות מושלמת (גרף א מימין), כל תמהיל של הון טבעי והון כלכלי הוא אפשרי על מנת לייצר מוצר (Q). אם לשוב לדוגמת הפחם והמכונות, ניתן לשמור על רמת תפוקה זהה אם מוסיפים מכונות בהדרגה וזונחים לחלוטין את הפחם. כמו כן הגדלת התוצר (מעבר מ־Q1 ל־Q2 עשויה להיות כרוכה בהוספה של סוג אחד של הון בלבד, משמע התוצר אינו תלוי בהון טבעי (יש הנחות נוספות ברקע הגרף, בדבר גודל האוכלוסייה וקצב השיפור הטכנולוגי,58 שהן מחוץ למתחם סקירה זו). לנפש לאורך זמן רב, גם בהתחשב בגידול אוכלוסין.

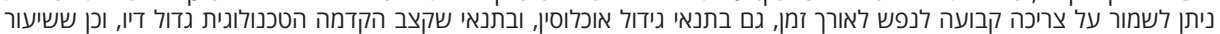
התפוקה שמוקצה להשקעה בבסיס ההון של החברה הולם את הנסיבות. 
בהנחת תחליפיות חלקית (גרף ב במרכז) לא ניתן להפיק מוצרים ללא תערובת כלשהי של גורמי ייצור. אומנם גמישות התחלופה (אשר נעה בין 1 ל־0) מאפשרת להמיר כמות מסוימת של הון טבעי בהון כלכלי, ולהפך, תוך כדי שמירה על רמת תוצר קבועה, אך כמות מינימלית של הון טבעי (פחם) נחוצה בכל תרחישי הייצור.

בהנחת גמישות התחלופה האפסית (גרף ג משמאל) לא ניתן להחליף פחם במכונות כלל, לא ניתן להפיק מוצרים (בנקודות המפגש של הקווים) ללא שתי התשומות, ולא ניתן להגדיל את התוצר (מעבר מנקודת העיקול של Q1 לנקודת העיקול של Q2) ללא תוספת של שני סוגי הנכסים.

דברים אלו מסכמים את הרעיונות העיקריים, אשר על אף ההפשטה הקיצונית בהצגתם מעוררים דיונים ביכולת התחלופה של נכסים וברמת הקריטיות שלהם (כאמור, תלות בנכס ללא תחליף היא תלות קריטית). את הדיונים האלו יש לערוך גם בנכסים אחרים, במחלקות הון אחרות בתכלית ובהקשר בן זמננו (הקשר דמוגרפי, הקשר תרבותי והקשר טכנולוגי).59 לפי פרמן ואחרים (Perman et al., 2011), המסקנה האוניברסלית הנובעת מכל הניתוחים הללו היא ששמירה על איכות חיים לאורך זמן כרוכה בכמה תנאים: התנאי הראשון הוא רמת תחליפיות גבוהה בין סוגי משאבים; התנאי השני הוא קצב גבוה של קדמה טכנולוגית; התנאי השלישי הוא קצב גידול אוכלוסין אפסי, או שלילי, תלוי בתנאים הפרטיקולריים של כל משק לאומי. עם זאת יש מחלוקת בשאלה אם תנאים אלו עשויים להתקיים.

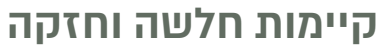

על אף חשיבותה של יכולת התחלופה בין נכסי הון שונים הדעות על מידת התחלופה בין הון טבעי להון מלאכותי חלוקות. מחנה אחד, מחנה האופטימיזם הטכנולוגי, מחזיק בדעה שקדמה טכנולוגית תבטיח תחליפיות בפונקציית הייצור ושיפור מתמיד באיכות החיים הכללית. כלומר, מחנה זה מניח אפשרות של גמישות תחלופה מושלמת (גרף א). המחנה האחר, המחנה הסקפטי, גורס שהיכולת הטכנולוגית להמציא תחליף לכל משאב סביבתי ולהתגבר אגב אורחא על כל קושי מתעורר, כמו זיהום, היא יכולת מוגבלת. לפי הדוקטרינה, אין כל ערובה שקצב Basiago,) החדשנות הטכנולוגית ישיג את קצב הגידול בצריכה לנפש ואת גידול האוכלוסין

59 למעשה, ניצבות לפנינו שתי אפשרויות תחלופה שונות: תחליפיות תוך־הונית ותחליפיות בין־הונית. תחליפיות תוך־הונית תכווין אותנו

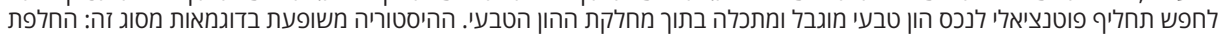

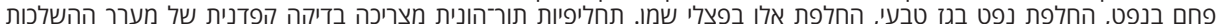

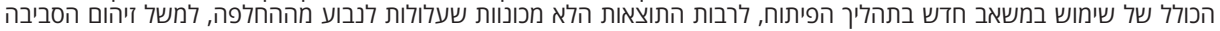

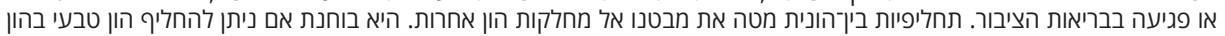

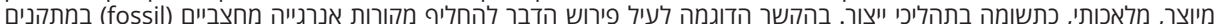
הידרו־אלקטריים, גאו־תרמיים, תרמו־סולריים או קינטיים, בתהליכי הפקת חשמל. במנגנונים של סחר חוץ מדינת לאום לפום עשויה להחליף תלות־עצמית במלאי הון בעל זיקה לאומית גאוגרפית, במלאי הון מיובא. פירוש הדבר שדיון באפשרות התחלופה של של נכסי הון דורש לעיתים גם בחינה גאופוליטית ומעלה שאלות של ביטחון לאומי החורגות מגבולותיה של סקירה זו. 
1994). יתרה מזאת, עבור נכסים סביבתיים מסוימים אין בנמצא תחליף (גרף ב, או בגרסתו הרדיקלית יותר - גרף ג) (Brand, 2009). מיותר כמעט לציין שתצפיות אמפיריות מן העבר אינן מעידות על העתיד להתרחש, ומאחר שכך, הוויכוח בין המחנות אינו ניטש על תשתית עובדתית כי אם על תפיסות עולם.

המחלוקת סביב שאלת התחליפיות שכיחה בספרות האקדמית המתהווה בתחום הקיימות.

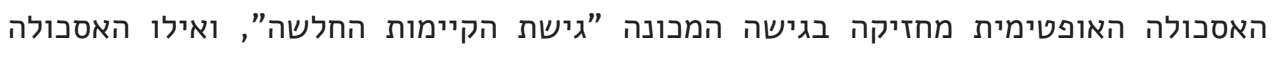
השמרנית מכונה "גישת הקיימות החזקה". הן נבדלות זו מזו בחומרת התנאים שעלינו לקיים על מנת להבטיח קיימות (קיימות כשם תואר; קיימות של איכות חיים, של פיתוח אנושי וכן הלאה) (Neumayer, 2003). שתי הגישות מבקשות לקיים את התנאים הנדרשים להבטחת איכות חיים מתמשכת. גישת הקיימות החלשה, שעימה נמנים חוקרים כמו הארטוויק וסולו, גורסת שתנאים אלו אינם נוקשים: עלינו לבצע החלפות של הון טבעי מתכלה בהון כלכלי מתחדש מעת לעת, ובכך להבטיח רמת צריכה קבועה לנפש, או רמת תועלת קבועה לנפש, לזמן בלתי מוגבל. מכאן נובע שאפשרויות התחלופה בין תשומות בתהליכי פיתוח וייצור הן רבות ביותר. מנגד, תומכי הקיימות החזקה סוברים שאפשרויות התחלופה מוגבלות, ועל כן התנאים לשמירה על רמת איכות החיים נוקשים: עלינו להקפיד כי ההון הטבעי, על כמויות

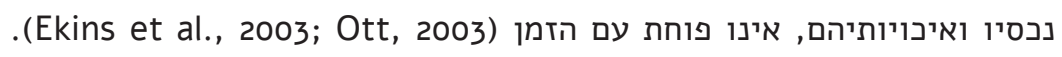
מבלי לנקוט עמדה בפולמוס המתמשך יש להתחשב בכמה אלמנטים שמסייגים את רעיון התחלופה, על אחת כמה וכמה אם מעוניינים ליישם אותו בסדרות נכסים במחלקות הון אחרות: אנושי, חברתי ותרבותי. כפי שנטען קודם לכן, מלאי הון אינו אובייקט יחיד והומוגני: הוא עשוי מרכיבים. מרכיבים אלו בעצמם ירשו את האופי ההטרוגני של מה שאנו מכנים מחלקת הון: הם זרויים באקראי בטריטוריות שונות, תצורתם לא אחידה, איכותם לא קבועה ומשתנה על פני זמן. בפועל מצבורים של משאבי טבע מאופיינים בהרכבים כימיים, במבנים גבישיים ובתכונות פיזיקליות שונות ובתנאי שטח שונים. בפועל ניתן להחליף נכס אחד באחר, או כך לפחות בנכסי הון טבעי (החלפה בין מתכות). עוד במקרה של משאבי טבע, עד תחילת תהליך ההפקה, ובמקרים רבים גם אחריו, המלאי הסופי אינו ידוע. כמו כן רק שיעור מסוים מהכמות הפיזית של המשאב זמינה לכלכול. יתרה מזאת, הקהילה המחקרית טרם סיימה לאמוד במלואו את סך שירותי המערכת האקולוגית שהחברה האנושית מוטבת שלהם, שירותים

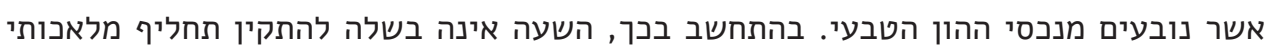
עבורם בפונקציית הייצור. לבסוף, גם אם בתקופה כלשהי רמת התחלופה בין שני נכסי הון הייתה גבוהה, אין בכך כדי להעיד על גמישות התחלופה העתידית. כל אלו מסבכים את התאוריה המסורתית.

הדיון במבחני הקריטיות הציע כי עלינו להעדיף את הדיון בנכסי הון שהם חסרי תחליף. 
אולם הטמעתו של רעיון גמישות התחלופה בשדה התאורטי של גישת ההון אינו מובן מאליו, לכל הפחות באשר לסוגי הון אחרים שאינם ההון הטבעי, והוא צריך להיבדק בעיון תאורטי (Perman et al., 2011). יש לבחון אמפירית את אפשרויות התחלופה, בכל מקרה לגופו, בכל מחלקת הון ובכל עת אל מול נכסים אחרים. בד בבד יש לבחון גם את ההיבטים הערכיים המעורבים בקביעת אפשרות התחלופה של נכסים משום שלא כל תחליף הוא בהכרח ראוי

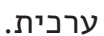

\section{ההיבט הנורמטיבי של שאלת התחלופה}

גמישות התחלופה של נכסים (ורמת הקריטיות שלהם) נקבעת לא רק מטעמים מדעיים, Pelenc \&) פיזיקליים וביולוגיים אלא גם מטעמים ערכיים ותרבותיים. לפי פלנק ובאלט Ballet, 2015 , הקביעה כי נכס הון טבעי מסוים הוא קריטי אינה נסמכת רק על קריטריונים אקולוגיים אובייקטיביים, אלא גם על השקפות עולם, על שיקולים נורמטיביים, על אתיקה ועל גישה כללית לסיכונים המניעים גם את הניצול, ההפקה והכלכול של הון טבעי (Dedeurwaerdere, 2014). למשל, תפיסת הקריטיות של שירותי המערכת האקולוגית היא תוצר של שיקולים ומדדים אקולוגיים, חברתיים, תרבותיים, פוליטיים וכלכליים, ומכאן Arias-Maldonado,) ש"קריטיות" וכן "גמישות תחלופה אפסית" אינן קטגוריות אבסולוטיות 2015 ראוי ל־ב", הן החלטות נורמטיביות, סובייקטיביות, ומכאן מוטות, שיכולת המדע חסר הפניות לפתור אותן היא מוגבלת (Chiesura \& Groot, 2003; Ekins et al., 2003) אמת זו תופסת גם כשמדובר במחלקות הון אחרות, על סדרות נכסיהן. הדיון באפשרויות

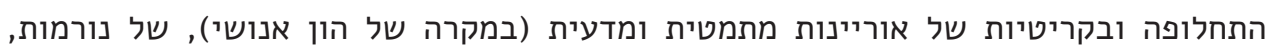
כמו שוויון בפני החוק, של אמון כללי ושל רשתות קהילתיות (במקרה של הון חברתי), של

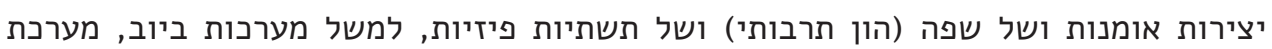
ייצור, הולכה והספקה של חשמל או טכנולוגיות תקשורת ומידע (הון כלכלי מיוצר, המכונה

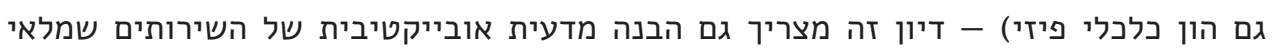
הון אלו מספקים לחברה וגם שיג ושיח על אודות הערכים והמטרות של מגזרי אוכלוסייה באשר למלאים אלו. ההשלכות של הדיון בשאלת התחלופה הן מעשיות וניהוליות. נוכח נכסים מוגבלים, מתכלים,

60

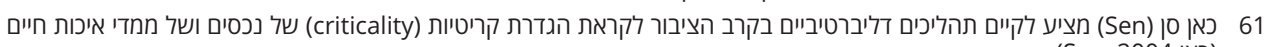
(Sen, 2004 (ראו 
חסרי תחליף במתחם הריבונות הלאומית, על מנהל המשק להכריע אם משאבים יוקצו להגנה על נכסים אלו מפני שימוש יתר ופחת, אם נכון לנקוט צעדים דרסטיים וליישם את עקרון הזהירות המונעת על סעיפיו (Kriebel et al., 2001), ובד בבד אם נכון להקים מערך טכנולוגי כדי להגדיל את גמישות התחלופה, ואם ניתן - להגות ולספק תחליף ראוי, מדעית ותרבותית, לנכס ההון ולשירותים החברתיים שנכס ההון מציע. הפרק הבא עוסק בטכנולוגיה מנקודת

\section{טכנולוגיה, קריטיות ותחליפיות של נכסי הון}

לטכנולוגיה יש חשיבות מכרעת ברעיון פונקציית הייצור וכן באיכות חיים בת־קיימה. פונקציית הייצור מניחה אפריורית את קיומה של טכנולוגיית ייצור כלשהי, שהיא חיצונית לפונקצייה עצמה: בהינתן טכנולוגיית ייצור, הפונקצייה קובעת אילו תשומות יש לערבב כדי להפיק תוצר מסוים. כאשר טוענים שכושר הייצור עלה (פרודוקטיביות) עבור אותן תשומות (מלאי ההון), מניחים שיפור טכנולוגי. בגרסה נודעת אחת של הפונקצייה, גרסת קוב-דאגלס (Cobb-Douglas production function), שיפור ארוך טווח בכושר הייצור, שבא לידי ביטוי בגידול בתוצר (Q), או במקרה זה Y, מושג באמצעות גידול ב"גורם פרודוקטיביות כללי" (Aigner \& Chu, 1968) (A)

$$
\mathrm{Y}=\mathrm{AL}^{\alpha} \mathrm{K}^{\beta}
$$

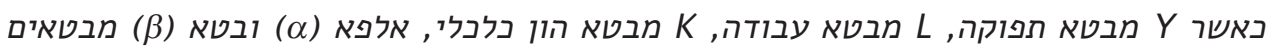

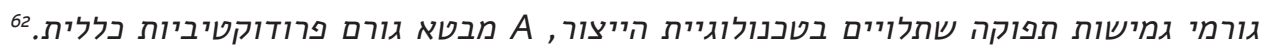
הכלכלה מורה לנו לראות בטכנולוגיה, לפחות לפי רעיון פונקציית הייצור, את מערכת המכשירים שבאמצעותה תהליכי הייצור מתבצעים. אם כן, חדשנות טכנולוגית היא המניע של התייעלות ארוכת טווח בתהליכי הייצור. בכוחה לפרוץ את "גבול אפשרויות הייצור" (המכונה גם עקומת התמורה): להגדיל את כמות התוצר בשימוש באותן התשומות או לשמור על כמות 
התוצר בשימוש בתשומות מעטות יותר.63 אולם מההמשגה העכשווית לטכנולוגיה עולה כי היא שוכנת, למעשה, בשני צידי המשוואה וגלומה במלאי הון באופנים שונים. ארתור מפציר בנו לחשוב על טכנולוגיה כעל קולקצייה עצומה של מכשירים ושל שיטות; מיומנויות, תהליכים,

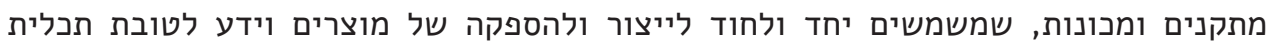
חברתית. לשיטה זו, הטכנולוגיה היא "בכל מקום ובכל זמן", והיא אינה מוגבלת לאובייקטים מכניים פיזיים או אוטומטות (automata) (Arthur, 2009) (64) מכאן שהטכנולוגיה חובקת את התוצר, את אופני הייצור ואת אמצעי הייצור. היא מעין נופך נוסף של מחלקות ההון המלאכותיות, על סדרות נכסיהן. בדיון באיכות חיים בת־קיימה יש לחשוב על התכלית החברתית של הטכנולוגיה, כפי שארתור מדגיש, אך ביתר ספציפיות יש לשאול כיצד הטכנולוגיה עשויה לשמור על רמת איכות החיים לאורך זמן. שאלה זו נוגעת בתלות בנכסי הון שהוגדרו כקריטיים. ייתכן שהטכנולוגיה יכולה להפחית תלות זו, להמציא תחליף ראוי לנכסי ההון הקריטיים או להרחיב את גמישות התחלופה שלהם. דסגופטה ציין שש קטגוריות של טכנולוגיות תחליף שעשויות לחולל תמורה באופן הניצול של ההון הטבעי, וסקירה זו מוסיפה עליהן עוד שתי קטגוריות: • טכנולוגיה להגדלת הפרודוקטיביות בתהליך הייצור או טכנולוגיית התייעלות בשימוש במשאבים (למשל כמות הדלק הפוסילי הנדרשת להפקת קוט"ש חשמל). טכנולוגיה שמאפשרת לחומר קיים לשמש בכמה תהליכי ייצור. טכנולוגיית חומרים חדשים ותחליפיים (למשל בדים סינתטיים כתחליף לכותנה). טכנולוגיה שמוזילה את הפעילויות של חיפוש משאבי טבע והפקתם (למשל טכנולוגיית דימות ורפלקצייה סיסמית, אמצעי קידוח וכולי). • טכנולוגיה המאפשרת שימוש בחומרים באיכות נמוכה לאותן מטרות (סגסוגות מתכת).

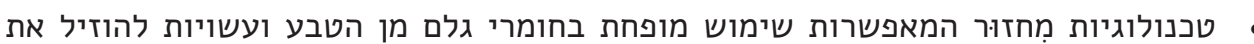
עלויות הייצור. • טכנולוגיות המאפשרות החלפה תוך־הונית מושלמת (חומר גלם אחד בחומר גלם אחר, ללא כל שינוי נוסף בתהליך הייצור). • טכנולוגיות המאפשרות החלפה בין־הונית מושלמת (הון טבעי מתכלה בהון כלכלי מיוצר)

.(Dasgupat, 1993)

63 זהו הקסם שברעיון ההתייעלות. כשמתמקדים בגורם הפרודוקטיביות הכללי A, תשומת הלב עוברת לשיפור תהליך הייצור ואינה

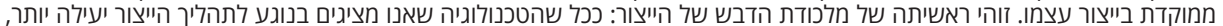

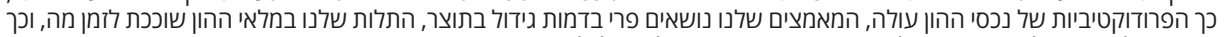
אנו "ננעלים" בתהליך. אפקט העלות השקועה, שהוא פסיכולוגי וכלכלי כאחד, אינו מיטיב עם המצב. יתרה מזאת, אם תשות השומות הייצור כוללות מלאי הון טבעי מתכלה, אזי השיפור הטכנולוגי בפרודוקטיביות של ההון הטבעי "דוחה את הקץ" ותו לא. דינמיקה דומה מתוארת

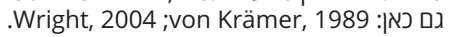
64 ארתור מגדיל וטוען שהטכנולוגיה ניחנה ב"טבע משל עצמה" (nature), ומכאן שניתן לייחס לה סגולות אבולוציוניות. "היא מתהווה

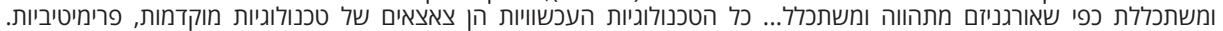

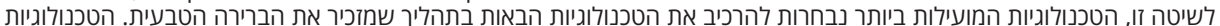
החדשניות והמשבשות ביותר הן שילוב של טכנולוגיות טובות מהעבר". הוא מכנה את התהליך הזה "אבולוציוציה קומבינטורית". לשון אחר, התפתחות וקדמה טכנולוגית כפועל יוצא של קומבינצינוזיות וזיווגים. 
רק אחד מן המכניזמים הללו מוגבל, לדעת דסגופטה ואחרים (Perman et al., 2011): התחלופה המלאה של הון טבעי מתכלה בהון טבעי מיוצר (בשל גמישות תחלופה חלקית). אולם כאשר הוא סוקר את נכסי ההון השונים (בהתמקדו במשאבים מינרליים ובהתעלמו משירותי המערכת האקולוגית), הוא מביע דאגה פורתא. בהנחה שהביקוש למשאבים ייוותר ברמתו, מלאי הפוספט עתיד להתכלות בתוך כ־1,300 שנים, וכל יתר המלאים אינם צפויים להגביל את הייצור הכלכלי. אם אנו מתאימים את התחזית לגידול אוכלוסין ולגידול בהכנסות לנפש, אזי מקורות הדלק המאובני "יספיקו רק לכמה מאות שנים. זה צוואר הבקבוק. זו

$$
\text { המגבלה", הוא הדגיש. }
$$

ניתן להציג כמה השלכות אפשריות של הדיון בטכנולוגיות התחליף גם על מחלקות הון אחרות: • הון אנושי: ההתפתחות הטכנולוגית פותחת בפנינו אופקים חדשים ואיתם הזדמנויות לערוך תמורות מרחיקות לכת בבסיס משאבי האנוש של החברה. די להתבונן באחד מסימני ההיכר של הצייטגייסט המודרני - לפחות מאז שנת 1956, עם טביעת המונח בוועידת דארטמות' (Dartmouth Conference) והיישומים של אותו עשור - הוא השיח הער על מכלול הכישורים שאנו מכנים "בינה מלאכותית" ופוטנציאל ההחלפה של עבודה אנושית

שסוג אינטליגנציה זה מציע (Frey \& Osborne, 2017). •ון חברתי: המבנים החברתיים שלנו (המוסדות, הקשרים החברתיים) חווים אבולוציה מדורזת בשל הופעתן של טכנולוגיות חדשות, למשל של רשתות חברתיות דיגיטליות. • הון כלכלי: מקומה של הטכנולוגיה בהקשרי ההון הכלכלי מעלה בין היתר את השאלה אם בעלות על נכסים טכנולוגיים לא מוחשיים היא אפשרית, למשל באמצעות זכויות קניין רוחני כפטנטים, זכויות יוצרים וסימני מסחר, ואם מלאי זה (מלאי הפטנטים) ראוי להיכלל ברשימת נכסי ההון הכלכלי הקריטיים. לכאורה, יש לו זיקה לאומית, התרומה שלו לצמיחת משקים לאומיים מכרעת, ואף שהוא עשוי להתחדש כמכלול (פונקצייה של מאמץ חברתי־אנושי־כלכלי מאורגן), מרכיביו הפרטיים מתכלים (הבעלות על פטנטים קצובה בזמן ובחולפו היא פגה). • הון תרבותי: האם האנתרופולוגיה והסמיוטיקה (semiotics of culture) מציעות לנו כלים אנליטיים לדון בחשיבות ההגנה על יצירות אומנות למשל כנכסים חברתיים בעלי תוּי הותי ערך, נכסי צאן ברזל, אפשר לומר, בעולם דיגיטלי הפוסע אל עבר רפרודוקציות מושלמות לארטיפקטים (אם מערכת היחסים בין המסמל למסומל משתנה; אם יש ערך אמיתי למסמל Hodge, 2014; (המקורי; אם תרבות היא אוסף של סמלים ולא אוסף של נכסים מוחשיים .(Bal \& Bryson, 1991; Chandler, 2017 אם כן, בחינת יחסי הגומלין שבין טכנולוגיה לקריטיות ולתחלופה של נכסי הון דורשת דיון 65 כמובן, מציינים פרמן ואחרים (ראו Perman et al., 2011 , לא כל הפרשנים מקבלים את הגישה האופטימית של דסגופטה. 
נרחב בהרבה. עם זאת, במילים כלליות, יש לטכנולוגיה אפשרות להשפיע על הקריטיות והתחלופה של נכסי ההון השונים: להמציא תחליפים לנכסי הון קריטיים או להגדיר מחדש את גמישות התחלופה שלהם; להאיץ את קצב הבלאי של נכסים קריטיים; לשנות את רמת הקריטיות של נכסי הון.

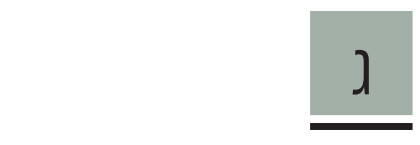

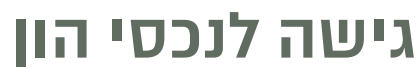

במידה רבה, על מנת שבני אדם יוכלו להשתמש בנכסי ההון השונים לצורך איכות חייהם צריך שתהיה להם גישה לנכסים אלה. הגישה לנכסי ההון מושפעת, לפחות בחלקה, מאופי הבעלות עליהם. זכות הקניין, שלא ממקומה של הסקירה להרחיב בעניינה, היא מבחינת תאוריית גישת ההון התערבות באינטראקציות הספונטניות בין מחלקות ונכסי הון בניסיון להסדיר אינטראקציות אלו ולאפשר גידור, הגנה על משאבים וטובין וסחר חליפין בהם (Demsetz, 1974). להתערבות זו, לעצם ההכרה בקטגוריות של קניין וקטגוריות של זכויות קניין, השפעות מרחיקות לכת על איכות החיים, ואלו סוגיות מוסדיות מן המעלה העליונה .(Di Gregorio et al., 2008) הספרות מציעה סיווג של נכסים וטובין, מוחשיים ולא מוחשיים, לארבע קטגוריות לפי זכויות הקניין שניתן להחיל עליהם: - (1) • נכסים ציבוריים: הגישה לטובין או לנכסים ציבוריים המכונים גם טובין קולקטיביים היא לא מוגבלת, והשימוש החופשי בטובין זה אינו תחרותי, קרי כל אחד יכול להשתמש במוצר, והשימוש של אחד אינו פוגע בשימוש של אחר. • נכסים משותפים: הגישה לטובין או למשאבים משותפים גם היא לא מוגבלת, ואולם השימוש בהם תחרותי: צריכת אדם אחד את המוצר מדללת את המלאי, ועל כן באה על חשבון צריכתו של אדם אחר את המוצר, או המשאב, היום או בעתיד (אם המשאב מתכלה). • נכסים קבוצתיים: הגישה למוצרים קבוצתיים או למוצרי מועדון היא מוגבלת אך ורק לחברי הקבוצה, ורק הם יכולים להפיק מהם תועלת. טובין אלה אינם מאופיינים בתחרותיות. • נכסים פרטיים: הגישה לנכסים פרטיים או לקניין פרטי היא מוגבלת ותחרותית כאחד: זכויות הקניין מונעות גישה למשאב, וכשבעליו משתמש בו, אחרים אינם יכולים להפיק

ממנו ערך (Bromley, 1991). 
סוג הבעלות על נכס ההון מעורר השלכות חשובות מבחינת איכות החיים ומידת קיימותה. למשל, לעיתים קיים ניצול יתר של מוצרים משותפים הנובע מהתופעה המכונה "הטרגדיה של נחלת הכלל" (Ostrom, 2015). דוגמה אחרת היא שלעיתים ניתן לחזות בשימוש לא הוגן במוצרים ציבוריים הנובע מהבעיה המכונה "אפקט הטרמפיסט" (Marwell \& Ames, 1979). לכן מרגע שנכסי הון קריטיים יזוהו, סיווג נוסף של הנכסים הקריטיים לפי ארבע הקטגוריות הוא מעשה חיוני, כמו גם זיהוי משטר הבעלות וזכויות הקניין החלות על כל נכס הון, למען התקנתו של מרשם ניהולי עבור המדינה.

בהקשרי איכות החיים משמעותם של הסדרי הגישה השונים לנכסי ההון נובעת גם משאלת השוויון (הן זה התוך־דורי והן זה הבין־דורי). לדוגמה, שאלה זו מתעוררת לנוכח התפלגות הבעלות על נכסי ההון הכלכלי באוכלוסייה (למשל נכסי דלא ניידי) המניבים תועלות לבעליהם. שאלת השוויון עולה גם כאשר דנים בנכסים שליליים, למשל חובות או זיהום סביבתי אשר הנטל שהם מהווים מונח על כתפי הדור הבא (Gosseries, 2008). גישת היכולות של סן מחדדת את החשיבות בשוויון בגישה לנכסי ההון הקריטיים. לפי סן, אם איכות חיים היא החירות וההזדמנות לממש את מאווייו של אדם ולעשות פעילויות המסיבות לו ערך וסיפוק, ואם הזדמנויות אלו של האדם מותנות בגישה למשאבים, אז גישה הוגנת למשאבים היא מהותית לאיכות חייו (Sen, 2009). כך, על המדינה לתת את הדעת לאי־שוויון בגישה לנכסי ההון הקריטיים לאיכות החיים ולהקפיד כי בעת מדידתם יהיה ייצוג לאופן התפלגות הבעלות נוות והגישה לנכסים אלה.66 עם זאת חשוב להדגיש כי הסדרי הבעלות על נכסי ההון אינם בהכרח דבר קבוע הנעוץ בטבעם. לפיכך בתנאים מסוימים ניתן לשנות את סוג הבעלות על נכס זה או אחר. משמעות שינוי סוג הבעלות, למשל מבעלות פרטית לבעלות ציבורית, היא שינוי בהסדרי הגישה אל נכס ההון: הרחקתו מהישג היד הציבורית, או לחלופין - קירובו. בדרך זו, לרשות המדינה עומדת לעיתים אפשרות להתמודד עם ההשלכות השונות של אופי הבעלות על נכסי הון מסוימים באמצעות שינוי אופי הבעלות עליהם.

66 אי־שוויון בגישה לנכסי הון קריטיים עלול לגרור פגיעה עקיפה באיכות החיים: אי־שוויון כזה עלול לפגוע בהון החברתי באמצעות שחיקה של תפיסת ההוגנות בחברה, כרסום ברמת האמון הכללי וערעור בסיס הערכים והסולידריות המשותפים. 


\section{T \\ אי־ודאות בעת השימוש בנכסי הון}

מצב מלאי ההון ונכסי ההון אינו ידוע לאשורו. כמותם ואיכותם ידועות רק בקירוב. בעיית אי־הוודאות מחזיקה במידה של תקפות גם בנוגע לרגישות הנכס ללחצים ולהשפעות חיצוניות, לקצב התחדשות הנכס (אם הוא אכן מתחדש) ולאפשרות החלפתו בנכסים אחרים. דרגה דומה של אי־ודאות אופפת גם את הצרכים העתידיים של החברה, ומכאן את היכולת שלנו לשמור על קצב ניצול או שימוש בר־קיימה. בתנאים אלו המשק הלאומי עלול לכלות את מלאי ההון העומדים לרשותו ולהעמיד את החברה כולה בסיכון לשחיקתה של רמת איכות החיים. בהיסח הדעת, הפעילות האנושית עלולה לחצות סיפים או לפרוץ גבולות של מערכות קריטיות, ובכך להוביל לפגיעה במלאי הון, בנכסים חיוניים, למשל קרקעות ומים, ולסיכון כללי לאוכלוסייה

(Rockström et al., 2009)

ניהול בתנאי אי־ודאות מחייב אפוא מנגנון להערכת סיכונים וניהולם (OECD, 2010). ניצול נכסי הון, בין אנושיים ובין טבעיים, צריך להיעשות מתוך תפיסת ניהול סיכונים מקיפה אשר בין היתר מתחשבת בהשלכות השונות של מדיניות השימוש במשאבים. בעיית ניהול בסיס המשאבים החברתי בתנאי אי־הוודאות אינה ייחודית, והיא רווחת בתהליכים שונים של קביעת מדיניות ציבורית (Ruckelshaus, 1983). כחלק מכך, אי־הוודאות האינהרנטית הכרוכה בניהול ההון הטבעי, הנובעת מרמת מורכבות התופעות, האובייקטים והתהליכים האקולוגיים, אשר יחד מספקים ערב רב של שירותים לאיכות החיים הכללית, הובילה לניסוח עקרון הזהירות המונעת (precautionary principle). לפי העיקרון, חיוניות הנכסים הטבעיים, פגיעותם ודפוסי התנהגות לא־ליניאריים של מערכות טבעיות (Lenton et al., 2008) מחייבים את הריבון להימנע ממהלכים שאין הוא יודע בוודאות גמורה שלא יסבו נזק. עיקרון זה רלוונטי להון האנושי ולבריאות הציבור כמו שהוא רלוונטי למדיניות הפקת נכסים טבעיים (Jackson)

.(\& Steingraber, 1999

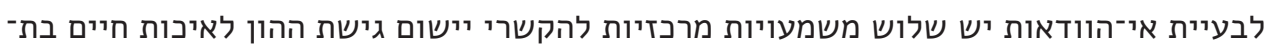
קיימה: ראשית, יש צורך לבחון אם ניתן להגדיל את רמת הוודאות בנוגע לכמותם, לאיכותם ולרגישותם של הנכסים החיוניים לניצול ולשימוש. שנית, יש לשקול אם רמת אי־הוודאות הכרוכה בניהול נכסי ההון מצדיקה את השימוש בעקרון הזהירות המונעת. שלישית, יש לזכור כי במידה רבה, מדידתם של נכסי ההון - ויהיו אלו מאגרי גז טבעי בשדות גז, האוריינות הטכנולוגית במגזרי אוכלוסייה, בריאות הציבור או רמת האמון ההדדי - עשויה להיות מוגבלת ולתת לנו רק בדיעבד תמונה מדויקת למצב נכסי ההון. 


\section{דרכים ושיטות למדידה של נכסי הון}

המלצה לדרכי מדידה של נכסי ההון הקריטיים לאיכות החיים חורגת מגבולותיה של סקירה זו, בין היתר משום שאין ביכולתה לערוך דיון מעמיק ומקיף דיו בזיהוי נכסים אלה. עם זאת היות שנודעת חשיבות רבה למדידת נכסי ההון הקריטיים לאיכות החיים, עולה שאלת הדרך היעילה ביותר לעשות זאת במסגרת לאומית. כפי שהוצע בעבר לא אחת, הדרך המועילה ביותר למדוד את נכסי ההון יחדיו כחלק ממערכת מדידה שלמה היא באמצעות שימוש ביחידות מדידה

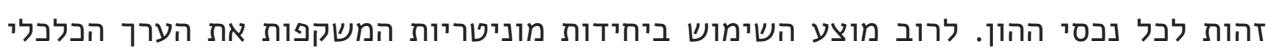

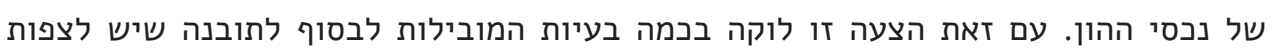
לשימוש במדדים מסוגים שונים עבור נכסים השונים זה מזה במהותם.

ראשית, התרומה העקיפה של נכסי הון אחדים לאיכות החיים, תרומה המתחוללת מחוץ לשוק הכלכלי, מקשה לקבוע את התועלת הכספית המדויקת שהם מסיבים לפרט: כיצד ניתן להעריך את התרומה של חינוך להורות טובה (Sewell \& Shah, 1968), או לחלופין, את התרומה של סביבה עירונית איכותית לבריאות נפשית (van Kamp et al., 2003); שנית, גם אם הייתה אפשרות לאמוד במדויק את התרומה של נכס כלשהו להיבטים השונים של איכות החיים, אפשר שהערכה כלכלית גרידא תהיה הערכה חלקית, מאחר שהערכות כלכליות רבות מבוססות על הנחות, ואלו חשופות להטיות ולשיקולים נורמטיביים; שלישית, רעיון הנכסים הקריטיים, שנדון לעיל, מציע אפשרות של גמישות תחלופה אפסית עבור נכסי הון מסוימים. התרומה של נכסים אלו לאיכות החיים חסרת תחליף, למשל מידה מינימלית של אמון הדדי או איכות מינימלית של אוויר נקי. ההנחה המקובלת אפוא היא שנכסים אחדים בבסיס המשאבים של אומה אינם נסחרים בשוק, ועל כן לא ניתן לבצע הערכה מוניטרית של שוויים. לכן מדדים מטיפוסים שונים נחוצים על מנת לנהל את בסיס המשאבים הלאומי. מערכת מדדי

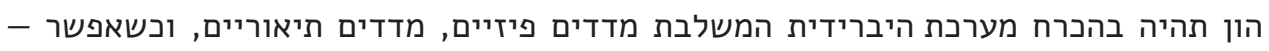
מדדים מוניטריים. יתר על כן, נכסי הון אחדים יצריכו מדדים אובייקטיביים, ואילו אחרים, למשל אמון הדדי, יחייבו מדדים סובייקטיביים אשר כפופים לשינויים תכופים ולהטיות קוגניטיביות נפוצות (McAllister, 1995). כמו כן עלינו להביא בחשבון מדדים לא־מוניטריים עבור אומדני השקעה (או חיסכון) ואומדני צריכה של נכסי הון שונים. 


\section{I \\ דינמיקת מערכות וחוסן}

יחסי הגומלין המתקיימים בין מחלקות ונכסי ההון הם רב־ממדיים ורב־תחומיים עד כדי כך שהם מציבים מכשלה בפני כל תחום דעת יחיד, למשל כלכלה, אקולוגיה, גאוגרפיה, הנדסה וכדומה, בעת פנייה למלאכת ניתוח הדינמיקה השוררת ביניהם. מורכבות ניתוח כזה תצטרך לכלול את הדינמיקה הבין־מחלקתית, התוך־מחלקתית, את הדינמיקה הפנימית שמאפיינת את נכסי ההון עצמם, ובכל זאת לתפוס קישוריות עצומה בין מספר כביר של מרכיבים ומרכיבי משנה. נכסי הון נטועים עמוק במערכות מורכבות ומשפיעים זה על זה, בין היתר בדרכים של היזונים חוזרים המכונים גם מעגלי משוב (feedback loops), דהיינו מנגנונים שבהם נכס הון א משפיע על נכס הון ב, וזה בתורו משפיע על נכס הון א וחוזר חלילה, עד שההתנהגות של שני הנכסים, התנהגות קו־אבולוציונית (Arthur, 2018), הופכת לא־ליניארית וקשה לתחזית. יתרה מזאת, אפשר שנכסי ההון עצמם ניחנים במורכבות פנימית ומקיפים מספר גדול של Bar-Yam, מרכיבים המשפיעים זה על זה, כאמור, ועל כן הם מערכות מורכבות בעצמם 1997).67 ככל ששיקופה של תאוריית גישת ההון את המציאות מהימן יותר, כך רמת המורכבות

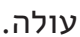

דרך התמודדות אחת עם מורכבות זו היא לסרטט גבולות מלאכותיים וצרים במיוחד סביב נכס bathtub) ההון, כפי שהדגים הדיון שערכנו בדינמיקת האמבטיה לעיל: מלאי אחד ושני זרמים (dynamics בפוטנציאל של השלכות ניהול המלאי. מודל פשוט זה משמש לתיאור האינטואיטיביות שבה ניחנת גישת ההון. עם זאת הוא פשטני מכדי לשמש תהליכים של קביעת מדיניות. מכל מקום, אם המטרה היא להתקדם אל מעבר להכרה בתאוריית גישת ההון, לסיווג של מחלקות הון ולזיהוי של נכסי הון קריטיים, אל עבר המלצה על רגולציה אפקטיבית של בסיס המשאבים הלאומי, עלינו להציע טכניקה כלשהי לניתוח האינטראקציות בין המלאים השונים בשדה. פתרון חלופי ומורכב יותר נעוץ במתודת דינמיקת המערכות שהפיצו למן שנות החמישים Meadows et) ומדוז (Morrester, 1997) ועוד רבים אחרים (Meadows, 2008) ועודים (al., 1972; Ogata, 1998

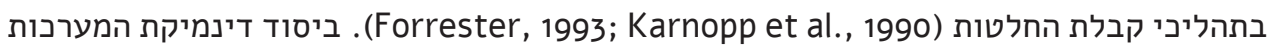

67 למותר לציין שהשפעות הדדיות אלו, יחסי הגומלין, התלות ההדדית השוררת בין נכסי הון - כל אלו צפויים להקשות ביצוע החלפה מלאה

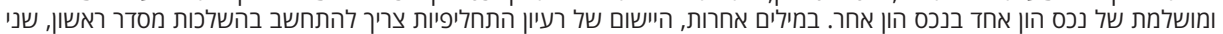
ויותר מזה של הסרת נכס הון ממארג הנכסים שבהם הוא נטוע. לעיתים, פרימת חוט אחד עלולה לפגוע במבנה האריג כולו. 
מונחים יחסי הגומלין הבסיסיים ביותר בין מלאים וזרמים.68 משום כך סקירה זו מוצאת את המתודולוגיה הולמת ביותר לביצוע אנליזות של מצב בסיס המשאבים של החברה; לאחוז את מורכבות האינטראקציות בבסיס המשאבים בקרניה.

בחסותה של גישה זו התפתחו הבנות מתקדמות בנוגע לאלה: טבען של מערכות מורכבות (למשל רשתות תחבורה, שווקים פיננסיים), לקסיקון קומפקטי לתיאור מרכיבי מערכת; מלאים וזרמים לתיאור תהליכים מערכתיים; מנגנונים של היזון חוזר וקטלוג אינטראקציות והשהיות; אפשרויות לטוויית גבולות סביב מערכות מבחן. הספרות בתחום עשירה בסימולציות למערכות פיזיות, וירטואליות ומשולבות: מוסדות חינוך, מפעלי תעשייה, ערים, משקים כלכליים ויערות. מודלים אלו מנפקים הסברים לערב רב של תופעות לא רצויות לרבות אבטלה, עוני, רעב והידרדרות בתנאי הסביבה. המודלים שהספרות רושמת מדגימים כשלים בניהול מערכות (לרבות כשלי שוק), הידלדלות של מלאי הון ונכסים קריטיים, ועל סמך חקר הכשלים דינמיקת המערכות מתווה דרכי פעולה להתערבות מושכלת במערכות (למשל הערכה מחדש של השהיות והערכה מחדש של גבולות).69

\title{
ים ניהול נכסי הון באמצעותה של שיטת דינמיקת המערכות
}

שימוש במתודולוגיה לטובת ניהול בר־קיימה של בסיס המשאבים הלאומי ועבור שקלול תמורות (tradeoffs) של הקצאות הון לצריכה שוטפת או לאפיקי השקעה חלופיים כרוך בהשלמת מידע בשנים־עשר מישורים שונים עבור כל מערכת של זרמים ומלאים, ובסינתזה של פיסות מידע אלו. כך ניתן לקבל תמונה מהימנה של מצב המערכות והתנהגות המערכות שדרכן הממשלה משתמשת בנכסי הון (למשל מערכת האנרגייה), או שדרכן הממשלה משקיעה

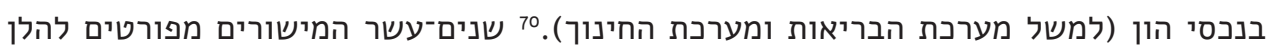
:(Meadows, 2008)

\author{
• • מידע על פרמטרים של המערכת.

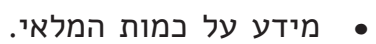 \\ • • מידע על תכונות של המלאי.
} • מידע על הזרמים אשר משפיעים על כמות המלאי ועל איכותו.

68 בדינמיקת מערכות בסיס המשאבים של החברה יבוטא באמצעות משתני מלאים (stock variables) אשר ייצגו את נכסי ההון בנקודת

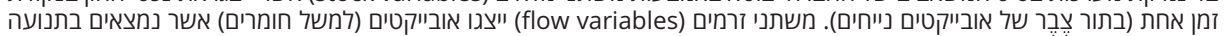
רציפה לאורך פרק זמן מוגדר (ועל כן הם נמדדים ביחס לזים לזמן), ונעים בצורות שונות, ובעוצמות שונות, ממלאי אחד למלאי אחר. סוגים שונים של מלאים יניבו סוגים שונים של זרמים. Sastry \& Sterman, 69

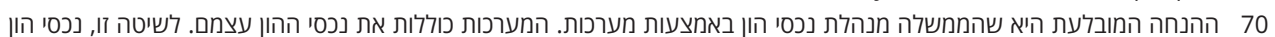

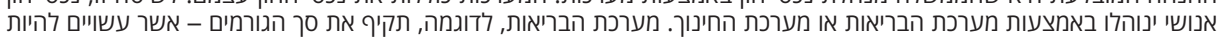
נכסי הון בעצמם, למשל מלאי הרופאים, האחים, מיטות האשפוז והציוד הרפואי - המעורבים בניהול הבריאות של האוכלוסייה (היא

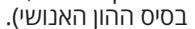


• מידע על הקשרים בין זרמים למלאים, למשל קיומם של "צווארי בקבוק". • מידע על השהיות במערכת, למשל קצב הזרימה של חומרים ושל אינפורמציה. מידע על מנגנונים של היזון חוזר. מידע על סוג ההיזונים החוזרים - אם הם חיוביים או שליליים.

מידע על איתותים של המערכת, האופן שבו ניתן ללמוד על מצבה ועל התנהגותה. מידע על העקרונות והכללים אשר מושלים בהתנהגות המערכת, אם היא כפופה לחוקי טבע כלשהם, אם היא כפופה לתקנות מוסדיות. מידע על כושר המערכת (היכולת הפנימית שלה) להשתנות לאורך זמן. מידע על תכליתה של המערכת.

כאמור, מנהל המערכת מסרטט את הגבולות סביבה וקובע היכן המערכת "מתחילה" והיכן היא "מסתיימת". לפיכך היקף המערכת - אשר עלול להיתוות בשרירות על בסיס העדפות אישיות או אידאולוגיות - יקבע את כמות הגורמים ואת מספר קשרי הגומלין השוררים בין הגורמים שיש להביאם בחשבון בעת בניית הסימולציה וביצוע האנליזה. חשוב מכך: סרטוט גבולות המערכת יכריע אילו גורמים אין ראוי להביא בחשבון (מהלך שאותו הכלכלה מכנה הַח החצָנָה - (externalization

\section{מערכות מורכבות וחוסן}

מתוך העיסוק במבנה, במצב ובהתנהגות של מערכות עשויה לנבוע, בין היתר, שאלת חוסנן של מערכות. לפי ההגדרות הרווחות בספרות, חוסן מבטא את יכולתה של מערכת לספוג הפרעות וזעזועים (disruptions) ולהתארגן מחדש, בתוך כדי שינויים שהיא (shocks, distubances) עוברת, ושומרת על אותם תפקודים מהותיים, על אותו מבנה, על אותה זהות ועל אותם מעגלי משוב (Walker et al., 2004; Holling, 1973; UNISDR, 2009; Sendzimir, 2006 בהקשר סקירה זו שני סוגים של השפעות חיצוניות עלולים להזיק לנכסי הון, וכפועל יוצא מכך - לאיכות החיים: הפרעות כרוניות שנובעות מתהליכים של ניצול יתר של הנכס - ולכן זעזועים שניתן לצפות אותם מבעוד מועד - והפרעות שנובעות מתופעות לא צפויות בעלות

71 למרבה התועלת, שיטת דינמיקת המערכות, בתור ענף אקדמי, אינה נושאת נס אידאולוגי, היא אינה מדיפה ניחוחות פוליטיים, והספרות

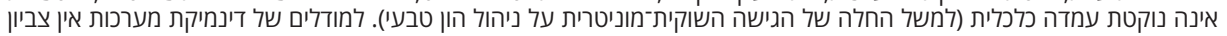
פילוסופי או מוסרי. הם אינם אומרים "מה טוב" ו"מה ראוי". המתודה מספקת מסגרת מדעית, נטולת משוא פנים, לתיאור תופעות לכות חברתיות (למשל היווצרותם של מונופולים או מלכודות עוני - poverty traps), לביאור החוקים שמושלים במערכות אלו ולהתערבות

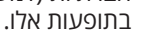

72 לפי רוקסטרום ואחרים, חוסן מקנה למערכת כלשהי את היכולת להתמיד (לספוג ולהתנגד לזעזועים), להסתגל ולהשתנות כשהיא נתונה

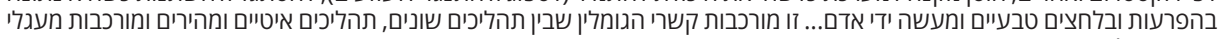

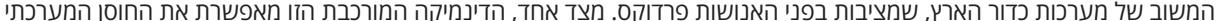
שמאפשר בתורו את מפעל הפיתוח האנושי, ומצד אחר המורכבות הזו מאלחשת אותנו לכדי תחושה מזוזיפת של ביטחון, היות ששינוינויים תוספתיים (incremental) יכולים להוביל אותנו לחצייה לא צפויה של סף שמעבר לו מערכות ותת־מערכות טבעיות יעברו למצב הרסני

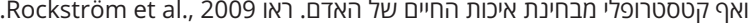


פוטנציאל הרסני.73 ראשית, מוסדות שונים עלולים לנצל את נכסי ההון ניצול יתר. הנסיבות Myers \& Worm, 2003; Worm et) ההיסטוריות של הפקת משאבים טבעיים מדגימות זאת (al., 2009; Humphreys, 2012 שלו בעתיד (אם הוא מתכלה), ואפשר שניצול יתר של נכס מסוים יפגע בנכסים אחרים שמקיימים עימו יחסי גומלין ותלויים בו (Islam \& Weil, 2000). בתנאים אלו הזעזוע הכרוך במיצוי מוחלט או בפרימה של נכס הון קריטי מרקמת הנכסים שבה הוא שזור עלול להוביל להפרעה רבתי במערכת האקולוגית או החברתית כולה, או למצער, ברכיבים מקומיים יותר של מערכות אלו - התא המשפחתי, היישוב והשוק. שנית, נכסים חיוניים והמערכות תומכות־ איכות־החיים התלויות בהם - מערכת הבריאות, מערכת המזון, מערכת החשמל או מערכת המסחר - חשופות גם להשפעות הרסניות לא צפויות, למשל אסונות טבע (OECD, 2013C). זאת ועוד, יש חוסן שאינו מבטא תכונה של מערכות מורכבות ש"מייצרות" את איכות החיים: זהו חוסן של הפרט או של משק הבית. כפי שכבר נאמר, "חוסן של אדם אינו זהה לחוסן של קהילה (מערכת חברתית) כפי שחוסן של עץ (החומר) אינו זהה לחוסן של יער (מערכת אקולוגית). את הראשון ניתן להגדיר בתור מיקרו־חוסן ואת השני בתור מאקרו־חוסן והם אינם זהים" (מדינת ישראל, 2016).75 עלינו להתחשב בדיסציפלינה וברזולוציה של השימוש במונח בעת הפעלתו בתהליכי עיצוב מדיניות וגיבוש מדדים. אם כן, יש שני סוגים אפשריים של הידרדרות באיכות החיים: הידרדרות צפויה מראש בעקבות מדיניות לאומית שמובילה לשחיקה של נכסי הון חיוניים, והידרדרות לא צפויה שנובעת מזעזועים "חיצוניים" למערכת הייחוס. לכן דאגה עמוקה לאיכות החיים, בהווה ובעתיד, אינה יכולה להתמקד רק בסוג ההידרדרות הראשון, אלא לתת את הדעת גם לשאלות של חוסן. על בסיס הבחנות אלו מומלץ להרחיב את הדיון בארבעה סוגים של מדדי חוסן:

• מדדים שעוקבים אחר שחיקה של נכסי הון קריטיים, אחר קצב שחיקתם ואחר מצבם. • מדדים המבטאים יכולת התמודדות של המערכות התומכות באיכות החיים עם זעזועים

$$
{ }^{76} \text { (כל מערכת ומאפייניה שלה) }
$$

• מדדי חוסן אובייקטיבים וסובייקטיביים של משקי בית, כשהדגש הוא על חוסן כלכלי.77

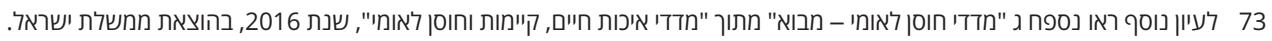

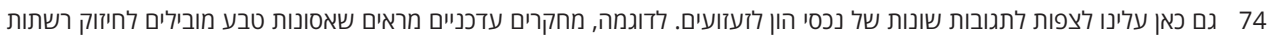

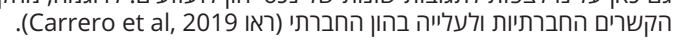
75 על ההבדל בין מיקרו־חוסן למקרו־חוסן ראו גם: 76

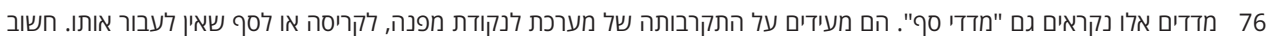

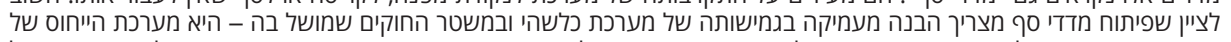

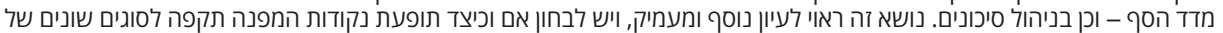
נכסי הון (באיזה שלב ניצול הופך לניצול־יתר, ואם שימוש במשאב יותר מרמה מסוימת מחולל תמורה במצב או בתכונות המשאב), וכיצד

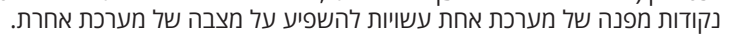

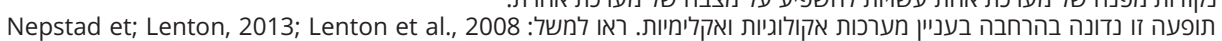
.Rocha et al., 2018; al., 2008 77 לדוגמה ראו את הדיון על הקשר בין עוני לאייוציבות כלכלית לאי־ודאות פיננסית ולזעזועים: Lusardi et al, 2011. 
• מדדים אובייקטיבים וסובייקטיביים של חוסן נפשי של הפרט. שאלת החוסן היא מורכבת, בעלת משמעויות עבור בסיס המשאבים הלאומי ועבור המערכות תומכות־איכות־החיים בכל מדינה. שאלה זו שוכנת מחוץ לגבולות הסקירה המדעית, והיא ראויה להתייחסות עתידית ומלאה.

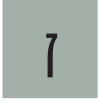

מדדי הון ומדיניות

העיסוק התכוף זה עשר שנים ויותר בתאוריית גישת ההון במסגרות פוליטיות מגוונות, ובהן באומות המאוחדות, באיחוד האירופי, ב־OECD ובזירות לאומיות, מדגים את השלכות היישומיות של התאוריה במדיניות, או לפחות את פוטנציאל ההשפעה שלה על תהליכי עיצוב

מדיניות.

התועלת הגלומה במערכת מדדים המשקפת את מצב המשאבים הלאומי נדונה בהרחבה במהלך הישראלי הלאומי בנושא, בין השנים 2012 ו־2016 (ממשלת ישראל, 2016). כאן ניתן להדגיש בתמציתיות את התרומה שהיא צפויה להרים לתהליכי הפקה והקצאה של משאבים, לקביעת סדרי עדיפויות בהשקעה במשאבים, לדיון בסוגיית השוויון בגישה למשאבים ובפיזור המשאבים באוכלוסייה, וליכולת להעריך את מידת הקיימות של איכות החיים בכללותה. התרומה לתהליכים אלו נובעת אפוא מהעשרת הדיון ברשויות השלטון, במסדרונות הממשל ובשדרה הציבורית במידע מדעי ועדכני על מלאי ההון.

במיוחד בתפקידם הפוטנציאלי כמחוונים למדיניות ציבורית78 מדדי הון מציעים מסגרת הוליסטית להערכת השפעות מדיניות לאורך זמן. בעזרתם נוכל לשער לדוגמה אם רפורמות כלשהן, או היעדרן של רפורמות, מובילים בחלוף הזמן להידלדלות במלאי המיומנויות באוכלוסייה.79 מסגרת מדדי הון תהיה ייצוגית מבחינת איכות החיים ומחולליה יותר ממערכת העתור החשבונות הלאומיים והמחוונים הראשיים של מערכת זו, ובכללם התוצר המקומי הגולמי .(Stiglitz et al., 2009) מודל לוח המחוונים (dashboard), כמטאפורה, מסייע לנו לדמיין את התרומה של מדדי 
הון לתהליכים רגולטוריים:80 ארגון הפעילות הקולקטיבית במשק והקצאת משאבים לאומית המבוססים על מחוונים לא־הוניים, ממוקדי־צמיחה־כלכלית, משולים לנהיגה ברכב בתוך שימוש במד המהירות גרידא, אשר מעיד על מהירות הרכב, אך אינו מלמד דבר על הגורמים המאפשרים את הנסיעה (מלאי הדלק, מלאי השמן, מלאי נוזל הקירור ומלאי נוזל הבלמים). מחווני מדיניות נוספים שמספקים אינדיקציה לבסיס המשאבים הלאומי נחוצים כדי להעריך אם רמת הצריכה הנוכחית פוגעת בהזדמנויות הצריכה של הדורות הבאים. בהיעדר מערכת מדדי הון שתזין תהליכי עיצוב מדיניות, קשה לדמיין דיון מושכל, מבוסס־עובדות, חף משיקולים זרים ומגחמות שעתיות, בעיזבון שהממשלה תותיר לדורות הבאים. במילים אחרות, מצב הדלק במכל, ולא מהירות הנסיעה, הוא מעניינו.

מרגע שמדדי ההון יפותחו, ייתנו פומבי למידע ויהיו זמינים לניתוחי מדיניות לגופי מחקר ולחברה האזרחית, נוכל להיטיב ולהקיש על הקשרים בין רגולציה לאיכות חיים מתמשכת. או אז נוכל לשאול אם הקצאת הון חוללה את התוצאות הרצויות; אם ניהול בסיס המשאבים הלאומי היה אפקטיבי; מהי התשואה החברתית על השקעה של נכסים בתהליכי ייצור שונים. נוכל לחקור אם וכיצד מהלך מדיניות צפוי להגביל את אפשרויות הצריכה בעתיד, ובכך לגרוע מרמת איכות החיים. על האופן שבו השדה האנליטי של תאוריית גישת ההון יועיל לדיון בין־משרדי, לאיגום

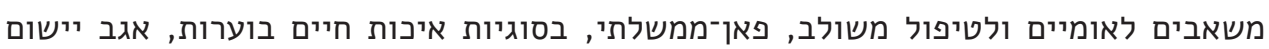
גישת הממשלה השלמה, ראו ספר מדדי איכות חיים, קיימות וחוסן לאומי משנת 2016. בקצרה, ניתן לסכם את פוטנציאל ההשפעה החיובית של תאוריית גישת ההון על תהליכים של קביעת מדיניות כך: • מדדים המבוססים על תאוריית גישת ההון לפיתוח בר־קיימה צפויים להעשיר את הדיון הפומבי - במסדרונות הממשל ובשדרה הציבורית - במידע מדעי ועדכני על אודות בסיס המשאבים הזמינים לחברה בכל רגע נתון. • מדדי תשומה, תפוקה ותוצאה המבוססים על תאוריית גישת ההון צפויים לסייע בהפקה ובייצור של משאבים. • מדדי הון צפויים לסייע בקביעת סדרי עדיפויות בהשקעה במשאבים. • מדדי הון צפויים לסייע בהסדרת גישה שווה למשאבים ובפיזור המשאבים באוכלוסייה. • בתור מחוונים למדיניות ציבורית, מדדי הון צפויים לסייע בהערכת השפעות מדיניות כלשהי לאורך זמן.

80 המטאפורה המלאה הוצגה זה מכבר בתהליך גיבוש מדדי איכות חיים לישראל, והיא מיושמת גם במקרה הבריטי, הניו־ילנדי ואצל

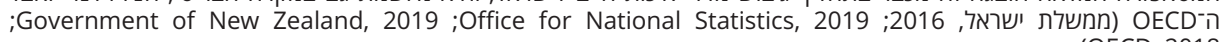
(OECD, 2018 
• מדדי הון צפויים לשפר את היכולת להעריך את מידת הקיימות של איכות החיים הכללית,

ועל בסיס הערכה זו - לקבוע אסטרטגיית איכות חיים לאומית. 


\section{יישומה של גישת ההון בישראל}

\section{דוגמאות לנכסים קריטיים בהקשר הישראלי}

חמשת מבחני הקריטיות שהוצעו קודם לכן - מבחן המוגבלות, מבחן ההתכלות, מבחן

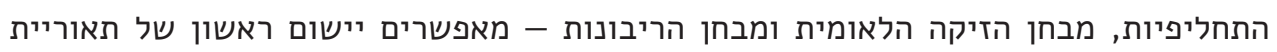
גישת ההון בהקשר הישראלי ולהציע דוגמאות לנכסים קריטיים בכל מחלקת הון. אין בהצעה שמועלית כאן כדי למצות את הדיון בנוגע לנכסי ההון הקריטיים לאיכות החיים בישראל אלא אך ורק להמחיש את האופן שבו ניתן ליישם את התאוריה של גישת ההון בהקשר הישראלי.

\section{הון כלכלי: מלאי הפטנטים}

מלאי הפטנטים שבבעלות מוסדות ציבור, פירמות ואזרחים ישראלים הוא תשומה קריטית

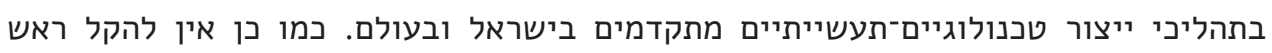
בתרומה של קניין רוחני, בדמות פטנטים, לצמיחה כלכלית בעידן המהפכה התעשייתית הרביעית (Idris, 2002). בגבולות המשק הישראלי מלאי הפטנטים מחזיק בתכונה כפולה של גורם ייצור, כאמור לעיל, ושל מדד תוצאה לרפורמות והשקעה ציבורית בתחומי ההשכלה, הקניית הכישורים והמיומנויות, החדשנות והמחקר והפיתוח.

בדומה לנכסי הון אחרים, יש טעם לפלח את מלאי הפטנטים לרשימת הפריטים שמרכיבים אותו: פטנטים בתחומי הכימיה והפרמצבטיקה, בתחום הביוטכנולוגיה ובתחום האלקטרוניקה, בין היתר. אין פירושו של דבר שכל פטנט מרים אותה תרומה לצמיחה כלכלית ולרווחה חומרית: התרומה של גלטירמר אצטט אשר נמכר בשם קופקסון (Copaxone) לטרשת נפוצה הסבה תועלת למשק הישראלי יותר מפטנטים רבים אחרים בתחום הפרמצבטיקה. 
בראי חמשת מבחני הקריטיות נכס הון זה עומד במבחן ההתכלות, שכן ההגנה על פטנטים קצובה בזמן, ולאחר מכן הזכות הקניינית מתחסלת. כמו כן הנכס עומד במבחן התחליפיות בהקשר של תהליכי ייצור כלכליים ספציפיים שבהם הפטנט חסר תחליף (כלומר פטנט המשמש בתהליך ייצור ייחודי הוא בעלת גמישות תחלופה אפסית). בשל התרומה של התעשייה עתירת הידע למשק הישראלי מלאי הפטנטים הוא בעל זיקה חזקה לאיכות החיים החומרית הכללמשקית, והוא משחק תפקיד בהקניית זהות לאומית קולקטיבית.81 לבסוף, המדינה משחקת כמה תפקידים מהותיים ביצירה של מלאי זה, הן בשלבים מוקדמים של הקניית כישורים לבעלי הפטנטים (העתידיים) באמצעות מערכת החינוך והן במגוון מסלולי תמיכה בתעשייה עתירת הידע, למשל באמצעות רשות החדשנות.

\section{הון טבעי: משאב הקרקע ועתודות הקרקע}

למשאב הקרקע ייעודים אפשריים שונים לרבות חקלאות, תשתיות, תעסוקה, מגורים ושטחי ציבור. שטחים פתוחים - ייעוד נוסף אפשרי של משאב הקרקע - מספקים טובין, מוצרים ושירותים, שמסיבים תועלות ישירות ועקיפות, מוחשיות ולא מוחשיות, (Vejre et al., 2010) לרווחה החומרית ולאיכות החיים הכללית של הציבור בישראל. קרקעות אחרות, עירוניות למשל, אינן מספקות חוויה אסתטית דומה והשראה לתרבות ולאומנות, בין היתר, כפי שמסיבים לאדם השטחים הפתוחים. יתרה מזאת, השטחים הפתוחים, שמורות הטבע והגנים הלאומיים, בתפקידם כבתי גידול (habitat), תומכים במגוון הביולוגי הקריטי לתפקוד הכללי

של מערכות אקולוגיות (Dobson et al., 2006).

מלאי השטחים הלא־מופרים בישראל (עתודות הקרקע) מוגבל, ואילו הביקוש לשטחים גדל, מטעמים של גידול אוכלוסין ופּרבור (או זחילה עירונית - urban sprawl), ובקשות להתרחבות פעילויות תעשייה, חקלאות ותיירות, בין היתר. גם במקרה זה יש מקום לפלח את מלאי הקרקעות לפי הפריטים המרכיבים אותו: שטחים פתוחים, לא מבונים, שטחים פתוחים שקיימת עבורם תוכנית בינוי מאושרת, שטחים חקלאיים, קרקעות עירוניות והיתר. בראי חמשת מבחני הקריטיות, נכס הון זה עומד בכל החמישה במידה המחמירה ביותר. מלאי הקרקעות של ישראל הוא סופי, מוגבל וחסר תחליף (חלקן חשוף לתהליכים של בלייה והתכלות). הזיקה בין הקרקעות - על שימושיהן השונים - לאיכות החיים ישירה וחזקה, וברי כי הקרקעות נמצאות בריבונות המדינה ומנוהלות באמצעות מוסדות רבים, למשל רשות מקרקעי ישראל. 


\section{הון אנושי: מלאי מיומנויות האוכלוסייה הבוגרת}

מלאי זה, אשר נמדד מדידה מייצגת בתוכנית הערכה בין־לאומית של מיומנויות בוגרים, המכונה גם סקר OEAC של ה־OECD (OECD, 2016) מקיף שלוש מיומנויות ליבה הנדרשות להשתלבות מוצלחת בשוק העבודה במאה העשרים ואחת. שלוש המיומנויות הן: אוריינות קריאה, כישורים מתמטיים ופתרון בעיות בסביבות עתירות טכנולוגיה. מלאי מיומנויות אלו

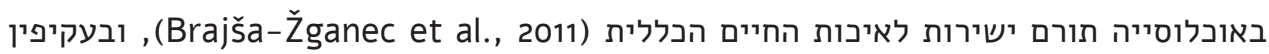
תורם לה באמצעות תהליכי ייצור בשוק. היבט זה של ההון האנושי הוא קריטי לאיכות החיים: בהיעדר השקעה הוא עלול להידלדל, תנאים רעועים עלולים להגביל ייצור, וגמישות התחלופה שלו עם נכסי הון אחרים שואפת לאפס. בראי חמשת מבחני הקריטיות, נכס הון זה עומד במבחן המוגבלות - גודל האוכלוסייה מוגבל, ורכישת המיומנויות נעשית בשלבים ספציפיים ביותר של רכישת השכלה. הואיל והמיומנויות גלומות באוכלוסייה, וזו עוברת תהליכים של התכלות (טבעית), נכס ההון עומד גם במבחן ההתכלות. נוסף על זה, חיוניותן של מיומנויות אלו במשק הכלכלי (במונחי פריון) מקשה על מציאת תחלופה ראויה בתהליכי ייצור שונים במיוחד בכלכלת הידע. כמו כן המדינה מוסמכת, ויש ביכולתה, לנהל את הצבירה של הון זה באמצעות מערכת החינוך.

\section{הון חברתי: אמון}

רבות דובר בחשיבותו המכרעת של אמון, נכס הון חברתי לא גשמי, לפעילות הכלכלית. אלגאן וקהוק מצאו מתאם גבוה בין אמון למדדים כלכליים אחרים: צמיחה, שוויון בגישה להזדמנויות

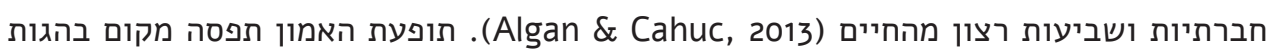
של קנת' ארו (Hall, 2001; Arrow, 2000), שטען ש"כל פעילות כלכלית כרוכה באמון, לא כל שכן פעילות כלכלית מתמשכת", והמשיך וגרס "ניתן לייחס נחשלות כלכלית לחוסר אמון הדדי" (Algan \& Cahuc, 2013) בדומה לזה, דסגופטה וסרגלדין הדגישו את התרומה של אמון הדדי (אמון בין פרטים) ואמון שאינדיווידואלים רוחשים למוסדות ולתהליכים של פיתוח אנושי (Dasgupta \& Serageldin, 2000). בראי חמשת מבחני הקריטיות, נכס הון זה עומד במבחן ההתכלות, הזיקה והריבונות. בנסיבות חברתיות מסוימות אנו עשויים להבחין בשחיקה של אמון כללי, אמון הדדי ואמון של פרטים במוסדות ממשל (Warren et al., 2014; Pew Research Center, 2019). אם ניתן לתחום

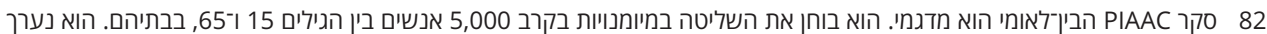

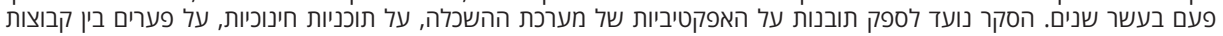

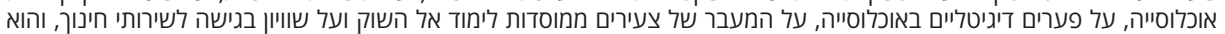
מגדיל לקשור בין ביצועים ובין רקע חברתי־כלכלי, בריאותי ודמוגרפי. 
שחיקה זו לגבולות לאומיים, ואם ניתן להתרשם כיצד אמון ירוד מצמצם מעורבות אזרחית (Yang, 2006), אזי ברור כי היא מעניינה של המדינה הריבונית. בנוגע לגמישות התחלופה של הנכס עם נכסים אחרים (מבחן התחליפיות), נדמה כי זו אפסית. במונחי תרומה לאיכות חיים ולכל ההיבטים החברתיים בהוויה האנושית, אין לאמון תחליף. גם בתנאים של אינטראקצייה וירטואלית בעידן המודרני נדמה כי האפראטוס הדיגיטלי מציע מנגנונים בוני־אמון, ומכל Möhlmann,) מקום הוא אינו מחליף אמון אלא מאפשר נסיבות שבהן אמון נוצר או נשחק .(2016; Schreieck et al., 2018

\section{הון תרבותי: האוסף הארכאולוגי במוזיאון ישראל}

האוסף הארכאולוגי במוזיאון ישראל עשוי אובייקטים עתיקים, יצירות אומנות וחפצים היסטוריים אשר הגישה אליהם חופשית לכאורה (בתמורה לעלות כלשהי), והם מגוללים את קורות ההיסטוריה של ארץ ישראל, מהתקופה הנאוליתית, דרך התקופה הכנענית, עבור בהתיישבות הישראלית בתקופת התנ"ך ועד ימי הממלכה הצלבנית והמוסלמית שהחליפה אותה - כפי שקורות אלו מיוצגים בארטיפקטים השונים, רבים מתוכם יחידים במינם וחסרי תחליף. האוסף מציע ערך תרבותי רב־ממדי, שכולל השראה אסתטית ואומנותית, והוא אתר מורשת בעל משמעות היסטורית, חברתית וחינוכית. האוסף משחק תפקיד בהקניית הזהות הקולקטיבית של תושבי ארץ ישראל, וגם מכאן נובעת חשיבותו לאיכות החיים. האובייקטים המרכיבים את האוסף הארכאולוגי חשופים לבלאי (הם סובלים מפחת), ועל כן מצריכים השקעה בדמות תחזוקה. נכס הון זה והפריטים המרכיבים אותו עומדים אפוא במבחן המוגבלות והתחליפיות - חלקם יחידים במינם; במבחן ההתכלות - הם חשופים לתהליכים של בלאי; במבחן הזיקה הלאומית ובמבחן הריבונות זהו נכס "ישראלי" במהותו אשר מנוהל 

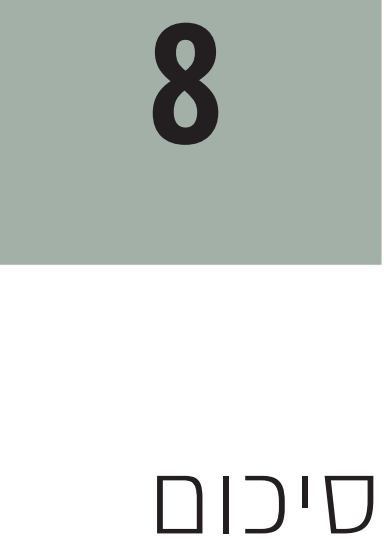

סקירה זו ביקשה לשפוך אור על תאוריית גישת ההון לקיימות. לפי התזה המרכזית של הגישה, בסיס המשאבים של חברה מספק לה את התנאים הנחוצים לחיים איכותיים. מכאן נובע שהתכלות בסיס המשאבים, המכונים גם מלאי הון, עלולה במוקדם או במאוחר להגביל את חופש הבחירה שלנו ולצמצם את איכות החיים הכללית. תזה זו זכתה כאן להרחבה כדי שתחול על שדה אנליטי ייחודי: שדה גישת ההון.

אל תוך שדה זה ייבאה הסקירה המדעית גורמים שונים אשר תורמים לאיכות החיים: מלאים של הון טבעי, אנושי, חברתי ותרבותי. עוד ייבאה הסקירה אל שדה גישת ההון מונחים וכלים אנליטיים אשר מיושמים עבור רעיון ה"הון" בדיסציפלינה הכלכלית ועשויים להועיל להבנה של הון מטיפוסים שונים בתכלית: צריכה והשקעה, גמישות תחלופה וגישה שווה, בין היתר. כך השדה הלוגי של גישת ההון מאפשר לנו לדון בכפיפה אחת בגורמים המשפיעים על איכות החיים השפעה נחרצת אשר בתנאים אחרים היו מפוזרים בין שדות דיסציפלינריים שונים. אף שרעיון היסוד של גישת ההון נהיר, כלומר ששיפור איכות החיים מותנה בניהול קפדני של הון כלכלי, הון טבעי, הון אנושי, הון חברתי והון תרבותי, היבטים אחדים של התאוריה דורשים עיון ביקורתי נוסף, ואילו היבטים אחרים מצריכים פיתוח. סקירה זו שאפה להציע מרחב לשוני ואנליטי שימושי לדיון בגורמים המחוללים של איכות החיים, ולצורך כך היא ניסתה ליישב מחלוקות אפיסטמולוגיות שעלולות להתעורר, לשלב תובנות אינטר־דיסציפלינריות בדרך לתיחום מחלקות ההון, לזהות ממדים ורכיבים של סוגי הון שונים, לנוע לעבר אחידות בשימוש במונח "נכס הון" ולפעול להניח תשתית לטקסונומיה אוניברסלית עתידית ושלמה. אך מהלך זה אינו שלם משום שהתאמתה של תאוריית גישת ההון לנסיבות המקומיות מצריכה רישום של נכסי ההון החיוניים ביותר במקרה הישראלי. שימת הדגש בנכסים מסוימים, הנכסים הקריטיים ביותר, החיוניים ביותר, לאיכות החיים בישראל - ולו לשם המלצה על סדרי עדיפויות בניטור, במדידה ובניהול ציבורי של נכסי הון - היא מעשה הכרחי. על כן הצענו חמישה מבחנים עבור המיקוד בנכסים מסוימים על פני אחרים: מבחן המוגבללוּת, מבחן ההתכלוּת, מבחן התחליפיות או גמישות התחלופה, מבחן הזיקה הלאומית ומבחן הריבונות. 
הסקירה אף הציגה כמה סוגיות מפתח שעימן יש להתמודד בכל ניסיון ליישם את תאוריית גישת ההון. היא דנה בשאלת גמישות התחלופה של נכסי ההון, הכרוכה במהודק בשאלת מידת הקריטיות שלהם. גמישות התחלופה, כאמור, היא מושג מפתח במדע הכלכלה אשר הסקירה המדעית ביקשה לשאול אל המרחב המאוחד של תאוריית גישת ההון, ומשם להשליך אותו על נכסי הון ממחלקות לא־כלכליות. הסקירה אף הדגישה שגמישות התחלופה של נכס הון איננה רק עניין טכני, כפוף לאמות מידה אובייקטיביות ומדעיות, אלא גם עניין ערכי.

הסקירה דנה גם במקומה של הטכנולוגיה בתוך המסגרת הרעיונית של תאוריית גישת ההון. איכות החיים, רעיון פונקציית הייצור (אשר משמש מטאפורה מרכזית בסקירה זו), קריטיות של נכסים, הגישה לנכסים וגמישות התחלופה שלהם - כולם מותנים, ביסודו של דבר, בטכנולוגיה. לפיכך הסקירה בחנה כיצד הטכנולוגיה עשויה לשמור על רמת איכות החיים לאורך זמן, אם בכוחה להקטין תלות בנכסים קריטיים או להרחיב את גמישות התחלופה שלהם. מכל מקום, ברור כי הדיון ב"טכנולוגיות התחליף", כפי שהן הוצגו בסקירה זו, נחוץ. הסקירה אף עסקה בשאלת הבעלות על נכסי הון: בעיה היסטורית כבירת ממדים. הסקירה הדגישה את חשיבות ההבחנה בין משטר הבעלות לזכויות הקניין החלות על כל נכס ונכס וכיצד אלו משפיעים על הגישה השווה לנכסים.

הסקירה העלתה את האפשרות של דינמיקת המערכות כמתודולוגיה טובה המספקת נקודת מבט אנליטית לתופעות הכוללות למשל הידלדלות של נכסי הון קריטיים. הסקירה העלתה כי דינמיקת המערכות מסייעת לנו לחקור את החוקים שמושלים במערכות מורכבות ולבחון את ההתערבות במערכות אלו. מתודה זו מאפשרת לנו לגשת למלאכת הניתוח של הדינמיקה השוררת בין מחלקות הון, בין נכסי הון ובין אלה לאלה באופן קוהרנטי ואינטואיטיבי. לבסוף, הסקירה הציעה דוגמאות לנכסי הון קריטיים לאיכות החיים בישראל. אף שהצעה זו רחוקה מלהיות שלמה או מקיפה, יש בה, בתקווה, נדי להעמיד בסיס לחקירת המשך בנוגע לנכסי ההון הקריטיים בהקשר הישראלי.

בשנת 1994 כתב רוברט סולו: "עבורי, הרעיון של גן עדן הוא מקרה שבו לתאוריה כלכלית... יש השלכות לעיצוב מדיניות" (Solow, 1994). איכות החיים, ולא כל שכן רעיון גן העדן, כפי שסקירה זו טענה - וטען גם אמרטייה סן - היא עניין פרטי ותלוי־העדפות. עם זאת המוטיבציה של הסקירה דומה למוטיבציה של סולו: שתאוריית גישת ההון תתווה תוכנית מדיניות לאיכות חיים מתמשכת. על כן לא נועדה הסקירה להוציא את ימיה בתוך הבניין

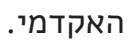
כמעט שלושים שנים של הגות בתחום תומכות במוטיבציה זו. הרעיון שבסיס המשאבים של 
החברה במובנו הרחב ביותר, על הנכסים הגשמיים והלא גשמיים הנמנים עימו, והמאפשר את איכות החיים, עשה כברת דרך. מוסדות אקדמיה שִׁכללו אותו, ארגונים בין־לאומיים תמכו בו, ממשלות לאומיות אימצו אותו, ואנרגייה אינטלקטואלית רבה עדיין מוקצית לבחינת רבדיו השונים. סקירה זו היא האחרונה במאמצים אלו, והיא מבקשת לתרום הן למחקר והן לפרקטיקה כדי להבטיח איכות חיים בת־קיימה. 

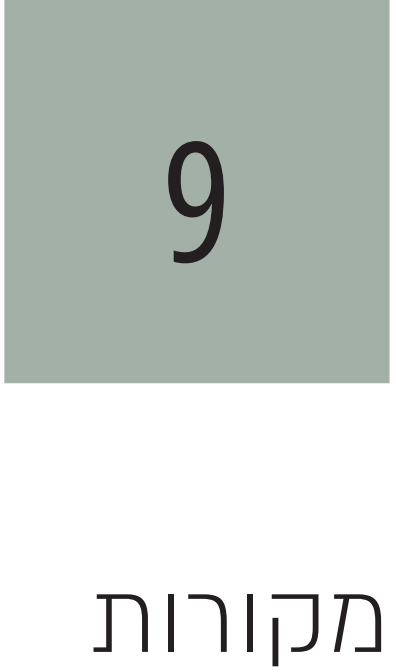

Acemoglu, D., \& Robinson, J. (2012). Why nations fail: The origins of power, prosperity, and poverty. Crown Publishing Group

Aghion, P., Algan, Y., Cahuc, P., \& Shleifer, A. (2009). Regulation and distrust. The Quarterly Journal of Economics, 125(3), 1015-1049

Aigner, D. J., \& Chu, S. F. (1968). On estimating the industry production function. The American Economic Review, 58(4), 826-839

Alderfer, C. P. (1969). An empirical test of a new theory of human needs. Organizational Behavior and Human Performance, 4(2), 75-142

Algan, Y., \& Cahuc, P. (2013). Trust and growth. Annual Review of Economics, 5, 521-549

Algan, Y., \& Cahuc, P. (2010). Inherited trust and growth. The American Economic Review, $100(5), 2060-2092$

Algan, Y., \& Cahuc, P. (2013). Trust growth and well-being: New evidence and policy implications, Discussion Paper No. 7464, The Institute for the Study of Labor, Bonn

Alkire, S. (2002). Dimensions of human development. World Development, 30 (2), 181-205

Alkire, S. (2010). Human development: definitions, critiques and related concepts. Research Paper 2010/01, Human Development Report. United Nations Development Program, New York

Allsopp, M. H., De Lange, W. J., \& Veldtman, R. (2008). Valuing insect pollination services with cost of replacement. PLoS One, 3(9), e3128

Andrews, D., \& Criscuolo, C. (2013). Knowledge-based capital, innovation and resource allocation. OECD Economics Department Working Papers, No. 1046. OECD Publishing

Anheier, H. K., Gerhards, J., \& Romo, F. P. (1995). Forms of capital and social structure in cultural fields: Examining Bourdieu's social topography. American Journal of Sociology, $100(4), 859-903$

Arias-Maldonado, M. (2013). Rethinking sustainability in the Anthropocene. Environmental Politics, 22(3), 428-446

Aristotle. Politics: A treatise on government (E. William Trans.). Lector House

Arrow, K. J. (1972). Gifts and exchanges. Philosophy and Public Affairs, 1(4): 343-362

Arrow, K. J. (2000). Observations on social capital. In P. Dasgupta and I. Serageldin (Eds.), Social capital: A multifaceted perspective (pp. 3-5). World Bank

Arthur, W. B. (2009). The nature of technology: What it is and how it evolves. Simon and Schuster

Arthur, W. B. (2018). The economy as an evolving complex system II. CRC Press

Ayres, R., Van den Berrgh, J., \& Gowdy, J. (2001). Strong versus weak sustainability: Economics, natural sciences, and consilience. Environmental Ethics, 23(2), 155-168 
Bal, M., \& Bryson, N. (1991). Semiotics and art history. The Art Bulletin, 73(2), 174-208

Barnosky, A. D., Matzke, N., Tomiya, S., Wogan, G. O., Swartz, B., Quental, T. B., ... \& Mersey, B (2011). Has the Earth's sixth mass extinction already arrived?. Nature, 471(7336), 51

Bar-Yam, Y. (1997). Dynamics of complex systems. Westview Press

Basiago, A. D. (1994). The limits of technological optimism. Environmentalist, 14(1), 17-22

Baym, M., Lieberman, T. D., Kelsic, E. D., Chait, R., Gross, R., Yelin, I., \& Kishony, R. (2016). Spatiotemporal microbial evolution on antibiotic landscapes. Science, 353(6304), 1147-1151

Becker, G. S. (1962). Investment in human capital: A theoretical analysis. Journal of Political Economy, 70(5, Part 2), 9-49

Becker, G. S. (2007). Health as human capital: Synthesis and extensions. Oxford Economic Papers, 59(3), 379-410

Becker, G. S. (2009). Human capital: A theoretical and empirical analysis, with special reference to education. University of Chicago Press

Bell, D. E. (1988). Decision making: Descriptive, normative, and prescriptive interactions. Cambridge University Press

Benhabib, J., \& Spiegel, M. M. (2005). Human capital and technology diffusion. Handbook of Economic Growth, 1, 935-966

Berkesl, F., \& Folke, C. (1994). Investing in cultural capital for sustainable use of natural capital. Investing in natural capital: The ecological economics approach to sustainability, 128

Black, A., \& Hughes, P. (2001). The identification and analysis of indicators of community strength and outcomes. Commonwealth Department of Family and Community Services

Bourdieu, P. (1986). The forms of capital. In J. Richardson (Ed.), Handbook of theory and research for sociology of education (pp. 241-258). Greenwood Press

Bowman, C., \& Swart, J. (2007). Whose human capital? The challenge of value capture when capital is embedded. Journal of Management Studies, 44(4), 488-505

Boyle, G. (2004). Renewable energy. Oxford University Press

Brajša-Žganec, A., Merkaš, M., \& Šverko, I. (2011). Quality of life and leisure activities: How do leisure activities contribute to subjective well-being?. Social Indicators Research, 102(1), 81-91

Brand, F. (2009). Critical natural capital revisited: Ecological resilience and sustainable development. Ecological Economics, 68(3), 605-612

Bromley, D. W. (1991). Environment and economy: Property rights and public policy. Basil Blackwell Ltd

Brown, R. R., Keath, N., \& Wong, T. H. (2009). Urban water management in cities: Historical, current and future regimes. Water Science and Technology, 59(5), 847-855

Bryan, B. A., Grandgirard, A., \& Ward, J. R. (2010). Quantifying and exploring strategic regional priorities for managing natural capital and ecosystem services given multiple stakeholder perspectives. Ecosystems, 13(4), 539-555

Buskens, V. (1998). The social structure of trust. Social Networks, 20(3), 265-289

Carrero, R., Acuto, M., Tzachor, A., Subedi, N., Campbell, B., \& To, L. S. (2019). Tacit networks, crucial care: Informal networks and disaster response in Nepal's 2015 Gorkha earthquake. Urban Studies, 56(3), 561-577

Castles, S., De Haas, H., \& Miller, M. J. (2013). The age of migration: International population movements in the modern world. Macmillan International Higher Education 
Chandler, D. (2017). Semiotics: The basics. Routledge

Chiesura, A., \& De Groot, R. (2003). Critical natural capital: A socio-cultural perspective. Ecological Economics, 44(2-3), 219-231

Clark, J. B. (1888). Capital and its earnings. Publ. Am. Econ. Assoc., 3(2), 9-69

Clark, J. B. (1891). Distribution as determined by a law of rent. Q. J. Econ., 5(3), 289-318

Clark, J. B. (1899). The distribution of wealth. A theory of wages, interest and profits. MacMillan

Clark, W. C. (2007). Sustainability science: A room of its own. PNAS, 104(6), 1737-1738

Clark, W. C., \& Dickson, N. M. (2003). Sustainability science: The emerging research program. PNAS, 100(14), 8059-8061

Clausen, J. A. (Ed.). (1968). Socialization and society. Little, Brown

Cohen, A. J., \& Harcourt, G. C. (2003). Retrospectives: Whatever happened to the Cambridge capital theory controversies?. Journal of Economic Perspectives, 17(1), 199-214

Cohen, J. E. (2010). Beyond population: Everyone counts in development. Center for Global. Development Working Paper, (220)

Coleman, J. S. (1988). Social capital in the creation of human capital. American Journal of Sociology, 94, 95-121

Corrado, C., Haskel, J., \& Jona-Lasinio, C. (2017). Knowledge spillovers, ICT and productivity growth. Oxford Bulletin of Economics and Statistics, 79(4), 592-618

Corrado, C., Hulten, C., \& Sichel, D. (2009). Intangible capital and US economic growth. Review of Income and Wealth, 55(3), 661-685

Costanza, R., d'Arge, R., De Groot, R., Farber, S., Grasso, M., Hannon, B., ... \& Raskin, R. G. (1997). The value of the world's ecosystem services and natural capital. Nature, $387(6630), 253$

Currie, J. (2009). Healthy, wealthy, and wise: Socioeconomic status, poor health in childhood, and human capital development. Journal of Economic Literature, 47(1), 87-122

Daily, G. C. (1997). Nature's services. Island Press

Dale, A., \& Newman, L. (2008). Social capital: A necessary and sufficient condition for sustainable community development?. Community Development Journal, 45(1), 5-21

Dasgupta, P. (1993). Natural resources in an age of substitutability. In A. V., Kneese, \& J. Sweeney (Eds.), Handbook of Natural Resource and Energy (Vol. 3). Elsevier

Dasgupta, P. (1995). An inquiry into well-being and destitution. Oxford University Press

Dasgupta, P. (2001). Human well-being and the natural environment. Oxford University Press

Dasgupta, P., \& Heal, G. (1974). The optimal depletion of exhaustible resources. The Review of Economic Studies, 41, 3-28

Dasgupta, P., \& Serageldin, I. (Eds.). (2000). Social capital: A multifaceted perspective. The World Bank

Dauber, E., Fredericksen, T. S., \& Pena, M. (2005). Sustainability of timber harvesting in Bolivian tropical forests. Forest Ecology and Management, 214(1-3), 294-304

De Graaf, N. D., De Graaf, P. M., \& Kraaykamp, G. (2000). Parental cultural capital and educational attainment in the Netherlands: A refinement of the cultural capital perspective. Sociology of Education, 92-111

Dedeurwaerdere, T. (2014). Sustainability science for strong sustainability. Edward Elgar Publishing 
Demsetz, H. (1974). Toward a theory of property rights. In C. Gopalakrishnan (Ed.) Classic papers in natural resource economics (pp. 163-177). Palgrave Macmillan

Deutsch, L., Folke, C., \& Skånberg, K. (2003). The critical natural capital of ecosystem performance as insurance for human well-being. Ecological Economics, 44(2-3), 205-217

Di Gregorio, M., Hagedorn, K., Kirk, M., Korf, B., McCarthy, N., Meinzen-Dick, R. S., \& Swallow, B. M. (2008). Property rights, collective action, and poverty: The role of institutions for poverty reduction. CAPRI working papers, 81

Dixit, A. P., Hammond, P., \& Hoel, M. (1980). On Hartwick's rule for regular maximin path of capital accumulation. The Review of Economic Studies, 47, 551-556

Dobson, A., Lodge, D., Alder, J., Cumming, G. S., Keymer, J., McGlade, J., ... \& Wall, D. (2006). Habitat loss, trophic collapse, and the decline of ecosystem services. Ecology, 87(8), 1915-1924

Durand, M. (2015). The OECD better life initiative: How's life? and the measurement of wellbeing. Review of Income and Wealth, 61(1), 4-17

Eagleton, T. (2014). Ideology. Routledge

Ehrlich, P. R. (1978). The population bomb. Ballantine Books

Ehrlich, P. R., \& Ehrlich, A. H. (1990). The population explosion. Simon and Schuster

Ekins, P. (2003). Identifying critical natural capital: Conclusions about critical natural capital. Ecological Economics, 44(2-3), 277-292

Ekins, P., Simon, S., Deutsch, L., Folke, C., \& De Groot, R. (2003). A framework for the practical application of the concepts of critical natural capital and strong sustainability. Ecological Economics, 44(2-3), 165-185

Ellison, N. B., Lampe, C., \& Steinfield, C. (2010). With a little help from my friends: How social network sites affect social capital processes. In Z. Papacharissi (Ed.), A networked self (pp. 132-153). Routledge

Fanny, B., Nicolas, D., Sander, J., Erik, G. B., \& Marc, D. (2015). How (not) to perform ecosystem service valuations: Pricing gorillas in the mist. Biodiversity and Conservation, 24(1), 187-197

Fisher, I. (1896). What is capital? Econ. J., 6 (24), 509-534

Fisher, I. (1897). Senses of capital. Econ. J., 7 (26), 199-213

Fisher, I. (1906). The nature of capital and income. MacMillan \& Co

Forrester, J. W. (1993). System dynamics and the lessons of 35 years. In K. B. De Greene (Ed.), A systems-based approach to policymaking (pp. 199-240). Springer

Forrester, J. W. (1997). Industrial dynamics. Journal of the Operational Research Society, 48(10), 1037-1041

Freeman, C., \& Soete. L. (2000). The economics of industrial innovation (3rd. ed.). Continuum

Frey, C. B., \& Osborne, M. A. (2017). The future of employment: How susceptible are jobs to computerisation?. Technological Forecasting and Social Change, 114, 254-280

Fukuyama, F. (1995). Trust: The social virtues and the creation prosperity. Free Press

Gemmell, N. (1996). Evaluating the impacts of human capital stocks and accumulation on economic growth: Some new evidence. Oxford Bulletin of Economics and Statistics, 58(1), $9-28$

Gosseries, A. (2008). Theories of intergenerational justice: A synopsis. S.A.P.I.EN.S, 1(1)

Government of New Zealand, the Treasury (2019). Measuring wellbeing: The LSF Dashboard 
Grootaert, C. (1997). Social Capital: The Missing Link?. In World Bank, Expanding the Measure of Wealth: Indicators of Environmentally Sustainable Development. Washington, D.C.

Grootaert, C., \& van Bastelaer, T. (2001). Understanding and Measuring Social Capital: A Synthesis of Findings and Recommendations from the Social Capital Initiative. The World Bank, Social Development Family, Environmentally and Socially, Sustainable Development Network

Grossman, M. (1972). On the concept of health capital and the demand for health. Journal of Political Economy, 80(2), 223-255

Guerry, A. D., Polasky, S., Lubchenco, J., Chaplin-Kramer, R., Daily, G. C., Griffin, R., ... \& Feldman, M. W. (2015). Natural capital and ecosystem services informing decisions: From promise to practice. PNAS, 112(24), 7348-7355

Hackett, S., \& Dissanayake, S. T. (2014). Environmental and natural resources economics: Theory, Policy, and the Sustainable Society. Routledge

Hall, J., Giovannini, E., Morrone, A., \& Ranuzzi, G. (2010). A framework to measure the progress of societies. OECD Statistics Working Papers, 2010/05, OECD Publishing

Hall, M. A. (2001). Arrow on trust. Journal of Health Politics, Policy and Law, 26(5), 1131-1144

Hallegatte, S. (2014). Economic resilience: Definition and measurement. The World Bank, Climate Change Group. Office of the Chief Economist. Policy Research Working Paper 6852

Halpern, D. (1999). Social capital: The new golden goose. Faculty of Social and Political

Hamilton, K., \& Hartwick, J. (2014). Wealth and sustainability. Oxford Review of Economic Policy, 30(1), 170-187

Hamilton, K., \& Hartwick, J. M. (2005). Investing exhaustible resource rents and the path of consumption. Canadian Journal of Economics, 38(2), 615-621

Harre, R. (1979). Social being. Oxford

Hartwick, J. M. (1977). Intergenerational equity and the investing of rents from exhaustible resources. American Economic Review, 66, 972-974

Hartwick, J. M. (1978a). Substitution among exhaustible resources and intergenerational equity. The Review of Economic Studies, 45, 347-354

Hartwick, J. M. (1990). Natural resources, national accounts, and economic depreciation. Journal of Public Economics, 43, 291-304

Hatch, N. W., \& Dyer, J. H. (2004). Human capital and learning as a source of sustainable competitive advantage. Strategic Management Journal, 25(12), 1155-1178

Healy, T., \& Côté, S. (2001). The well-being of nations: The role of human and social capital. Education and skills. OECD Publishing

Hediger, W. (2000). Sustainable development and social welfare. Ecological Economics, 32(3), 481-492

Hodge, B. (2014). Social semiotics. In B. Hodge, The Routledge Companion to Global Popular Culture (pp. 58-66). Routledge

Holling, C. S. (1973). Resilience and stability of ecological systems. Annual Review of Ecology, Evolution, and Systematics, 4, 1-23

Holt, D. B. (1998). Does cultural capital structure American consumption?. Journal of Consumer Research, 25(1), 1-25

Humphreys, D. (2012). Logjam: Deforestation and the crisis of global governance. Routledge

Idris, K. (2003). Intellectual property: A power tool for economic growth. WIPO 
International Monetary Fund (IMF). (2015). The Insatiable Demand for Sand. Available at: https://www.imf.org/external/pubs/ft/fandd/2015/12/edwards.htm

Islam, K. R., \& Weil, R. R. (2000). Land use effects on soil quality in a tropical forest ecosystem of Bangladesh. Agriculture, Ecosystems \& Environment, 79(1), 9-16

Jackson, W., \& Steingraber, S. (1999). Protecting public health and the environment: Implementing the precautionary principle. Island Press

Joad, C. E. M. (1957). Guide to philosophy. Courier Corporation

Johnson, A. S. (1902). Rent in modern economic theory: An essay in distribution. American Economic Association \& MacMillan

Johnson, A. S., 1909. Introduction to Economics. D.C. Heath \& Co

Kahneman, D., Diener, E., \& Schwarz, N. (Eds.). (1999). Well-being: Foundations of hedonic psychology. Russell Sage Foundation

Kampa, M., \& Castanas, E. (2008). Human health effects of air pollution. Environmental Pollution, 151(2), 362-367

Karnopp, D., Margolis, D. L., \& Rosenberg, R. C. (1990). System dynamics: A unified approach (2nd ed.). Wiley

Kolbert, E. (2014). The sixth extinction: An unnatural history. A\&C Black

Kriebel, D., Tickner, J., Epstein, P., Lemons, J., Levins, R., Loechler, E. L., ... \& Stoto, M. (2001). The precautionary principle in environmental science. Environmental Health Perspectives, 109(9), 871-876

Krugman, P., \& Wells, R. (2012). Economics (3rd ed.). Worth Publishers

Kulig, A., Kolfoort, H., \& Hoekstra, R. (2010). The case for the hybrid capital approach for the measurement of the welfare and sustainability. Ecological Indicators, 10(2), 118-128

Lamont, M., \& Lareau, A. (1988). Cultural capital: Allusions, gaps and glissandos in recent theoretical developments. Sociological Theory, 153-168

Lehtonen, M. (2004). The environmental-social interface of sustainable development: capabilities, social capital, institutions. Ecological Economics, 49(2), 199-214

Lenton, T. M. (2013). Environmental tipping points. Annual Review of Environment and Resources, 38, 1-29

Lenton, T. M., Held, H., Kriegler, E., Hall, J. W., Lucht, W., Rahmstorf, S., \& Schellnhuber, H. J. (2008). Tipping elements in the Earth's climate system. PNAS, 105(6), 1786-1793

Lundvall, B. A. (Ed.). (1992). National innovation systems: Towards a theory of innovation and interactive learning. Pinter Publishers

Lundvall, B. A., Johnson, B., Andersen E. S., \& Dalum, B. (2001). National systems of production, innovation, and competence building. DRUID's Nelson and Winter Conference Aalborg, 12-15 June. at: www. business.auc.dk/evolution/esapapers/esa01/RPike.pdf (accessed 19 November 2014)

Lusardi, A., Scheinder, D. J., \& Tufano, P. (2011). Financially fragile households: Evidence and implications. National Bureau of Economics Research

Magdol, L., \& Bessel, D. R. (2003). Social capital, social currency, and portable assets: The impact of residential mobility on exchanges of social support. Personal Relationships, 10(2), 149-170

Marwell, G., \& Ames, R. E. (1979). Experiments on the provision of public goods. I. Resources, interest, group size, and the free-rider problem. American Journal of Sociology, 84(6), 1335-1360 
Matson, P., Clark, W. C., \& Andersson, K. (2016). Pursuing sustainability: A guide to the science and practice. Princeton University Press

McAllister, D. J. (1995). Affect-and cognition-based trust as foundations for interpersonal cooperation in organizations. Academy of Management Journal, 38(1), 24-59

Mclntosh, R. P. (1986). The background of ecology: Concept and theory. Cambridge University Press

Meadows, D. H. (2008). Thinking in systems: A primer. Chelsea Green Publishing

Meadows, D. H., Meadows, D. L., Randers, J., \& Behrens, W. W. (1972). The limits to growth: A report to the club of Rome (1972). Google Scholar

Mincer, J. (1993). Investment in human capital and personal income distribution. Edward Elgar Publishing.

Mirowsky, J., \& Ross, C. E. (1998). Education, personal control, lifestyle and health: A human capital hypothesis. Research on Aging, 20(4), 415-449

Missemer, A. (2018). Natural Capital as an Economic Concept, History and Contemporary Issues, Ecological Economics, 143)C), 90-96

Möhlmann, M. (2016). Digital trust and peer-to-peer collaborative consumption platforms: $A$ mediation analysis. Available at SSRN 2813367

Myers, R. A., \& Worm, B. (2003). Rapid worldwide depletion of predatory fish communities. Nature, 423(6937), 280

Nepstad, D. C., Stickler, C. M., Filho, B. S., \& Merry, F. (2008). Interactions among Amazon land use, forests and climate: prospects for a near-term forest tipping point. Philosophical Transactions of the Royal Society B: Biological Sciences, 363 (1498), 1737-1746

Neumayer, E. (2003). Weak versus strong sustainability: Exploring the limits of two opposing paradigms. Edward Elgar Publishing

Neyman, J., \& Pearson, E. S. (1928). On the use and interpretation of certain test criteria for purposes of statistical inference. Biometrika, 20A(1-2), 175-240

Nussbaum, M. (2003). Capabilities as fundamental entitlements: Sen and social justice. Feminist Economics, $9(2-3): 33-59$

OECD (1998). Human Capital Investment: An International Comparison. OECD Publishing

OECD (2001). The Well-being of Nations: The Role of Human and Social Capital. OECD Publishing

OECD (2009). Measuring Capital. OECD Manual. OECD Publishing

OECD (2010). Risk and regulatory policy: Improving the governance of risk. OECD Publishing

OECD (2011). How's life?: 2011: Measuring well-being. OECD Publishing

OECD (2013a). Framework for statistics on the distribution of household income. Economic well-being Consumption and Wealth, Chapter 2. OECD Publishing

OECD (2013C). How's life? 2013: Measuring well-being. OECD Publishing

OECD (2013b). Supporting investment in knowledge capital, growth and innovation. OECD Publishing

OECD (2016). Skills Matter: Further results from the survey of adult skills. OECD Publishing

OECD (2018). Households' economic well-being: The OECD dashboard

Office for National Statistics (2019). Well-being: Measures of national well-being dashboard. ONS

Ogata, K. (1998). System dynamics (Vol. 3). Prentice Hall 
Oishi, S., Kesebir, S., \& Diener, E. (2011). Income inequality and happiness. Psychological Science, 22(9), 1095-1100

Ostrom, E. (2015). Governing the commons. Cambridge University Press

Ott, K. (2003). The case for strong sustainability. Greifswald's Environmental Ethics, 59-64

Parfit, D. (1982). Future generations: Further problems. Philosophy \& Public Affairs, 113-172

Paris, Q. (1992). The von Liebig hypothesis. American Journal of Agricultural Economics, 74(4), 1019-1028

Pearce, D. W., \& Atkinson, G. D. (1992). Are national economies sustainable?: Measuring sustainable development. Centre for Social and Economic Research on the Global Environment

Pearce, D. W., \& Atkinson, G. D. (1993). Capital theory and the measurement of sustainable development: An indicator of "weak" sustainability. Ecological Economics, 8 (2), 103-108

Pelenc, J., \& Ballet, J. (2015). Strong sustainability, critical natural capital and the capability approach. Ecological Economics, 112, 36-44

Pepper, S. C. (1937). Aesthetic Quality: A Contextualist theory of beauty. Charles Scribner and Sons

Perman, R., Ma, Y., McGilvray, J., Common, M., Maddison, D., \& Mcgilvray, J. (2011). Natural Resource and Environmental Economics. Pearson Education

Pew Research Center (2019). Public trust in government: 1958-2019. Available at: https:// www.people-press.org/2019/04/11/public-trust-in-government

Pigou, A. C. (1928). A study in public finance. Macmillan

Putnam, R. D. (1993). The prosperous community: Social capital and public life. The American Prospect, 13(Spring) (4), 35-42

Putnam, R. D. (1995). Tuning in, tuning out: The strange disappearance of social capital in America. PS: Political Science \& Politics, 28(4), 664-683

Rakodi, C. (2014). Urban livelihoods: A people-centred approach to reducing poverty. Routledge

Redman, J. C., \& Allen, S. Q. (1954). Some interrelationships of economic and agronomic concepts. Journal of Farm Economics, 36(3), 453-465

Regev, E. (2018). Israel needs a paradigm shift: Greater compatibility between human capital and the economy. The Israel Democracy Institute

Rinne, J., Lyytimäki, J., \& Kautto, P. (2013). From sustainability to well-being: Lessons learned from the use of sustainable development indicators at national and EU level. Ecological Indicators, 35, 35-42

Robbins, L. (2007). An essay on the nature and significance of economic science. Ludwig von Mises Institute

Robeyns, I. (2005). The capability approach: A theoretical survey. J. Hum. Dev. Capabilities, $6(1), 93-117$

Robinson, J. (2004). Squaring the circle? Some thoughts on the idea of sustainable development. Ecological Economics, 48(4), 369-384

Rocha, J. C., Peterson, G., Bodin, Ö., \& Levin, S. (2018). Cascading regime shifts within and across scales. Science, 362(6421), 1379-1383

Rockström, J., Steffen, W. L., Noone, K., Persson, Å., Chapin, F. S., Lambin, E., ... \& Nykvist, B. (2009). Planetary boundaries: Exploring the safe operating space for humanity. Ecology and Society, $14(2), 32$ 
Rockström, J., W. Steffen, K. Noone, Å. Persson, F. S. Chapin, III, E. Lambin, T. M ...\& J. Foley (2009). Planetary boundaries: Exploring the safe operating space for humanity. Nature, 461, 472-475

Rose, W. C. (1938). The nutritive significance of the amino acids. Physiological Reviews, 18(1), 109-136

Ruckelshaus, W. D. (1983). Science, risk, and public policy. Science, 221(4615), 1026-1028

Ruta, G., \& Hamilton, K. (2007). The capital approach to sustainability. Handbook of Sustainable Development, 45-62

Rydin, Y., \& Holman, N. (2004). Re-evaluating the contribution of social capital in achieving sustainable development. Local Environment, 9(2), 117-133

Salehi, B., Cordero, M. I., \& Sandi, C. (2010). Learning under stress: The inverted-U-shape function revisited. Learning \& Memory, 17(10), 522-530

Samuelson, P. A., \& Nordhaus, W. D. (2004). Economics. McGraw-Hill

Santayana, G. (1923). Scepticism and animal faith: An introduction to a system of philosophy. Charles Scribner's Sons

Sastry, M., \& Sterman, J. D. (1992). Desert island dynamics: An annotated survey of the essential system dynamics literature. System Dynamics Group, Sloan School of Management, Massachusetts Institute of Technology

Saunders, C. N., Kaye-Blak, W., Campbell, R. (March, 2010). Capital Based Sustainability Indicators as a Possible Way for Measuring Agricultural Sustainability. Research paper for the 84th Annual Conference of the Agricultural Economics Society, Edinburgh

Schneider, E. L., \& Guralnik, J. M. (1990). The aging of America: Impact on health care costs. Jama, 263(17), 2335-2340

Schreieck, M., Hein, A., Wiesche, M., \& Krcmar, H. (2018). The challenge of governing digital platform ecosystems. In C. Linnhoff-Popien, R. Schneider, M. Zaddach (Eds.), Digital marketplaces unleashed (pp. 527-538). Springer, Berlin, Heidelberg

Schultz, T. W. (1961). Investment in human capital. The American Economic Review, 1-17

Sen, A. (1985). Commodities and capabilities. Elsevier Science Pub. Co.

Sen, A. (1990). Development as capability expansion. The Community Development Reader, 41-58

Sen, A. (1999). Commodities and capabilities. OUP Catalogue

Sen, A. (2004). Capabilities, lists, and public reason: Continuing the conversation. Feminist Economics, 10(3), 77-80

Sen, A. K. (2009). The idea of justice. Harvard University Press

Sendzimir, J. (2006). Critical examination of resilience theories and measures. Report to CAVES Project (Complexity: Agents, Volatility, Evidence and Scale), Deliverable 6, EU 6th Framework.

Senor, D., \& Singer, S. (2011). Start-up nation: The story of Israel's economic miracle. Random House Digital, Inc

Sewell, W. H., \& Shah, V. P. (1968). Parents' education and children's educational aspirations and achievements. American Sociological Review, 191-209

Smith, A. (1776). An Inquiry into the Nature and Causes of the Wealth of Nations: Book 2 - Of the Nature, Accumulation, and Employment of Stock

Smith, R. L., Smith, T. M., Hickman, G. C., \& Hickman, S. M. (1998). Elements of Ecology 
Smith, R., Simard, C., \& Sharpe, A. (2001). A proposed approach to environment and sustainable development indicators based on capital. Prepared for The National Round Table on the Environment and the Economy's Environment and Sustainable Development Indicators Initiative, Canada

Social Development. Population Division (2002). World urbanization prospects: The 2001 Revision (No. 216). United Nations Publications

Solow, R. (1994). An almost practical step towards sustainability. Routledge

Solow, R. M. (1986). On the intergenerational allocation of resources. Scandinavian Journal of Economics, 88, 141-149

Souriau, E. (1943). Les différents modes d'existence. Presses Universitaires de France

Stern, D. I. (1997). The capital theory approach to sustainability: A critical appraisal. Journal of Economic Issues, 31(1), 145-174

Stiglitz, J. (1974). Growth with exhaustible natural resources: Efficient and optimal growth paths. The Review of Economic Studies, 41, 123-137

Stiglitz, J. E., Sen, A., \& Fitoussi, J. P. (2009). Commission on the Measurement of Economic Performance and Social Progress. Report by the commission on the measurement of economic performance and social progress

Stiglitz, J. E., Sen, A., \& Fitoussi, J. P. (2009). Report by the Commission on the Measurement of Economic Performance and Social Progress

Stiglitz, J., Sen, A., \& Fitoussi, J. P. (2009). The measurement of economic performance and social progress revisited: Reflections and overview. Commission on the Measurement of Economic Performance and Social Progress, Paris

Sullivan, A. (2001). Cultural capital and educational attainment. Sociology, 35(4), 893-912

Sweeney, L. B., \& Sterman, J. D. (2000). Bathtub dynamics: Initial results of a systems thinking inventory. System Dynamics Review, 16(4), 249-286

Sztompka, P. (1994). The sociology of social change. Blackwell

Sztompka, P. (1999). Trust: A sociological theory. Cambridge University Press

Tal, A. (2002). Pollution in a promised land: An environmental history of Israel. University of California Press

Throsby, C. D. (2005). On the sustainability of cultural capital (Vol. 510). Macquarie University, Department of Economics

Throsby, D. (1995). Culture, economics and sustainability. Journal of Cultural Economics, 19(3), 199-206

Throsby, D. (1999). Cultural capital. Journal of Cultural Economics, 23(1-2), 3-12

Turner, J. H. (1997). The institutional order: Economy, kinship, religion, polity, law, and education in evolutionary and comparative perspective. Longman Publishing Group

UNECE/OECD/Eurostat. (2008). Report on measuring sustainable development: Statistics for sustainable development, commonalities between current practice and theory. Working Paper ECE/CES/2008/29

UNECE/Eurostat/OECD Task Force. (2011). Summary of the report on measuring sustainable development, proposed indicators, and results of electronic consultation. Sixth meeting of the UN committee of experts on environmental-economic accounting, U.N. New York, 15-17 June, 2011

UNECE/OECD/Eurostat (2009). Measuring sustainable development, United Nations

UNFPA (2018). Aging. Available at: https://www.unfpa.org/ageing 
UNFPA (2018). World population trends. Available at: https://www.unfpa.org/world-populationtrends\#

UNISDR (2009). Terminology on disaster risk reduction. United Nations International Strategy for Disaster Risk Reduction. Geneva

United Nations Development Programme (1997). Human Development Report 1997: Human Development to Eradicate Poverty.

United Nations Economic Commission for Europe (2015). Sustainable development, website, accessed on May 01, 2019, URL: http://www.unece.org/oes/nutshell/2004-2005/focus_ sustainable_development.html

United Nations Environment (2014). Sand, rarer than one thinks. United Nations Global Environmental Alert Service

United Nations, European Commission, International Monetary Fund, Organization for Economic Cooperation and development, World Bank (2003). Integrated environmental and economic accounting 2003. Studies in Methods, Handbook on National Accounting (F, 61, Rev.1)

Uphoff, N. (2000). Understanding social capital: Learning from the analysis and experience of participation. Social Capital: A Multifaceted Perspective, 6(2), 215-249

Van Ark, B., Hao, J. X., Corrado, C., \& Hulten, C. (2009). Measuring intangible capital and its contribution to economic growth in Europe. EIB Papers, 14(1), 62-93

van der Ploeg, R. R., \& Kirkham, M. B. (1999). On the origin of the theory of mineral nutrition of plants and the law of the minimum. Soil Science Society of America Journal, 63(5), 1039-1482

Van Kamp, I., Leidelmeijer, K., Marsman, G., \& De Hollander, A. (2003). Urban environmental quality and human well-being: Towards a conceptual framework and demarcation of concepts; a literature study. Landscape and Urban Planning, 65(1-2), 5-18

Veblen, T. (1994) [1899]. The theory of the leisure class: An economic study of institutions. Penguin twentieth-century classics, Penguin Books

Vejre, H., Jensen, F. S., \& Thorsen, B. J. (2010). Demonstrating the importance of intangible ecosystem services from peri-urban landscapes. Ecological Complexity, 7(3), 338-348

Victor, P. A. (1991). Indicators of sustainable development: Some lessons from capital theory. Ecological Economics, 4(3), 191-213

Victora, C. G., Adair, L., Fall, C., Hallal, P. C., Martorell, R., Richter, L., ... \& Maternal and Child Undernutrition Study Group. (2008). Maternal and child undernutrition: consequences for adult health and human capital. The Lancet, 371(9609), 340-357

Von Krämer, W. (1989). Fortschrittsfalle Medizin (Medical progress traps), Der Spiegel, 13 March 1989

Walker, B. C., Holling, S., Carpenter, S. R., Kinzig, A. (2004). Resilience, adaptability and transformability in social-ecological systems. Ecology and Society, 9(2), 5

Warren, A. M., Sulaiman, A., \& Jaafar, N. I. (2014). Social media effects on fostering online civic engagement and building citizen trust and trust in institutions. Government Information Quarterly, 31(2), 291-301

Worm, B., Hilborn, R., Baum, J. K, Branch, T. A., Collie, J. S., Costello, C., ...\& Jensen, O. P. (2009). Rebuilding global fisheries. Science, 325, (5940), 578-585

Wright, R. (2004). A short history of progress. House of Anansi

Wyon, D. P. (2004). The effects of indoor air quality on performance and productivity. Indoor Air, 14(7), 92-101

Yang, K. (2006). Trust and citizen involvement decisions: Trust in citizens, trust in institutions, and propensity to trust. Administration \& Society, 38(5), 573-595 
הלשכה המרכזית לסטטיסטיקה. (2018). מדדי איכות חיים, קיימות וחוסן לאומי, 2016 הלשכה המרכזית לסטטיסטיקה. (2019). מדדי איכות חיים, קיימות וחוסן לאומי, 2017 מדינת ישראל. (2016). מדדי איכות חיים, קיימות וחוסן לאומי, 2015 תקשורת אישית, דסגופטה, פ., 2018 תקשורת אישית, פיטוסי, ג'.פ., 2017 תקשורת אישית, שטיגליץ, ג'., 2017 


\section{איכות חיים בת-קיימה בישראל דוח ועדת המומחים של האקדמיה הלאומית הישראלית למדעים \\ https://doi.org/10.52873/Policy.2021.Wellbeing}

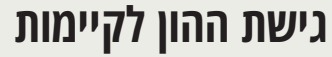

דיונים נבחרים בגישת ההון לקיימות

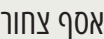

https://doi.org/10.52873/Policy.2021.Wellbeing.01

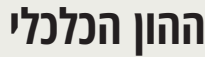

ההון הכלכלי, מרכיביו ותמונת המצב בישראל

מיכאל שראל - - - n

https://doi.org/10.52873/Policy.2021.Wellbeing.02

ההון הטבעי

הון טבעי והון טבעי קריטי בישראל

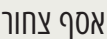

https://doi.org/10.52873/Policy.2021.Wellbeing.03

ההון האנושי

Israel - The Human Capital Perspective

Dov Chernichovsky

https://doi.org/10.52873/Policy.2021.Wellbeing.04-en

ההון החברתי

Building Social Capital for Sustainable

Well-Being in Israel: A Scientific Review Yinnon Geva, Itay Greenspan and Michal Almog-Bar https://doi.org/10.52873/Policy.2021.Wellbeing.05-en

ההון התרבותי

Culture and the Future Sustainability of Well-being in Israeli Society Tally Katz-Gerro https://doi.org/10.52873/Policy.2021.Wellbeing.06-en
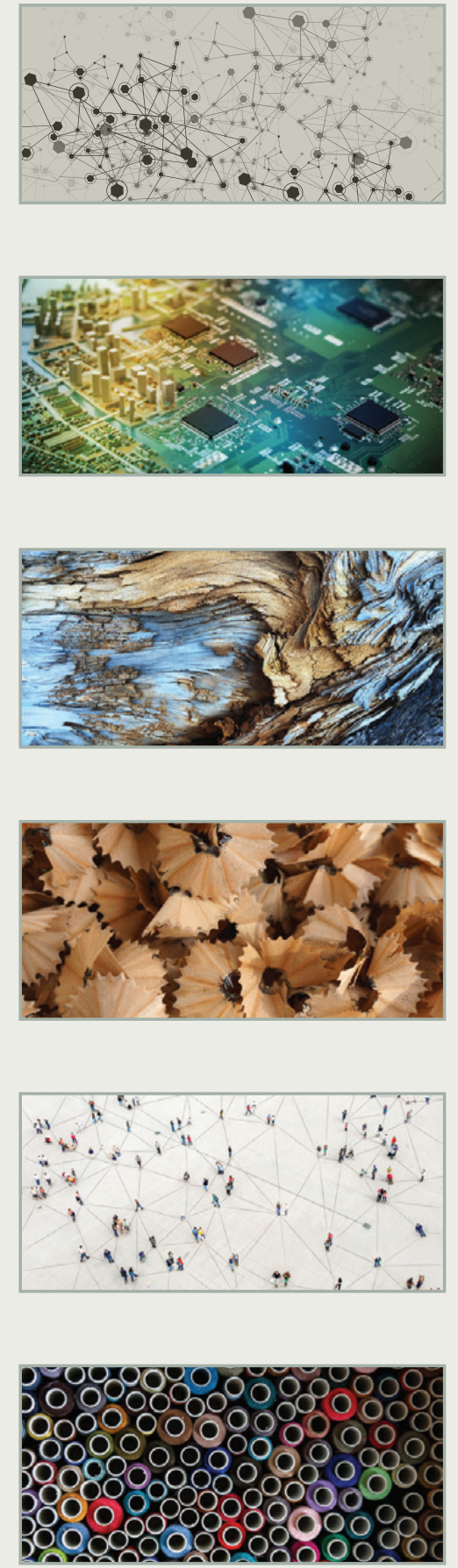